\title{
Evaluation of the U.S. Geological Survey Ground-Water Data-Collection Program in Hawaii, 1992
}

By Stephen S. Anthony

U.S. GEOLOGICAL SURVEY

Water-Resources Investigations Report 97-4232

Prepared in cooperation with the COMMISSION ON WATER RESOURCE MANAGEMENT, DEPARTMENT OF LAND AND NATURAL RESOURCES, STATE OF HAWAII 


\section{U.S. DEPARTMENT OF THE INTERIOR \\ BRUCE BABBITT, Secretary}

U.S. GEOLOGICAL SURVEY

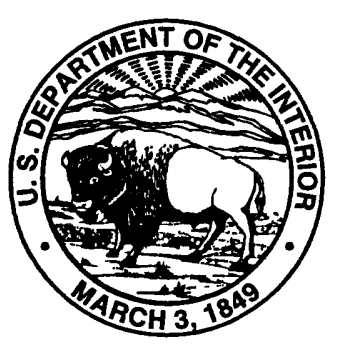

Mark Schaefer, Acting Director

The use of firm, trade, and brand names in this report is for identification purposes only and does not constitute endorsement by the U.S. Geological Survey.

For additional information write to:

Copies of this report can be purchased from:

District Chief

U.S. Geological Survey

677 Ala Moana Blvd., Suite 415

Honolulu, HI 96813
U.S. Geological Survey

Branch of Information Services

Box 25286

Denver, CO 80225-0286 


\section{CONTENTS}

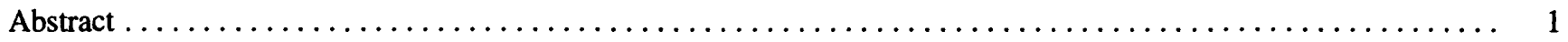

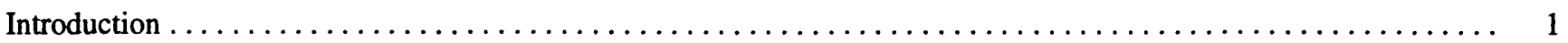

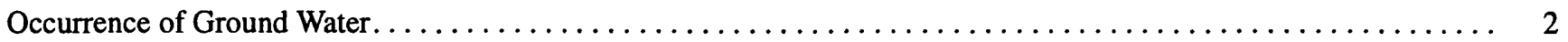

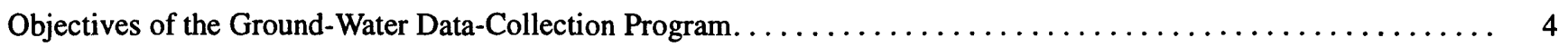

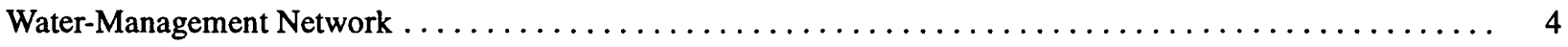

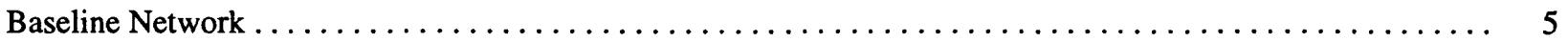

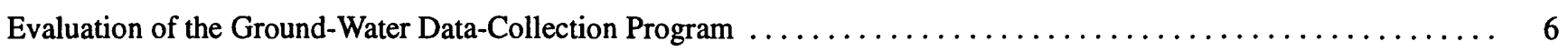

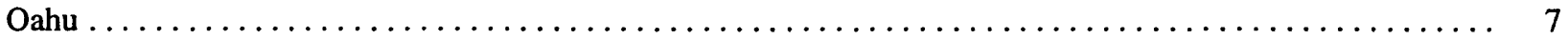

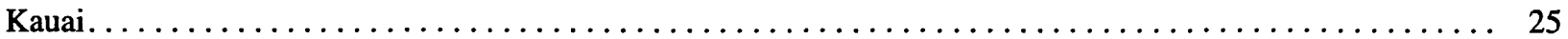

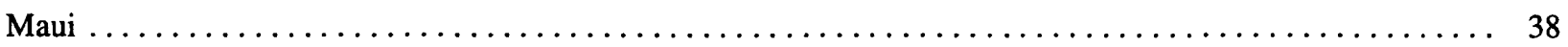

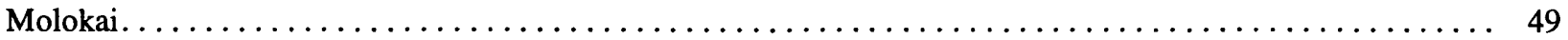

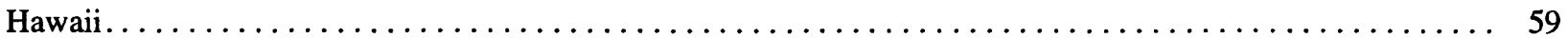

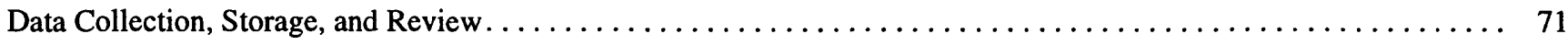

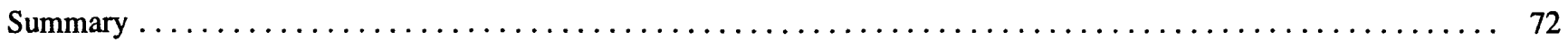

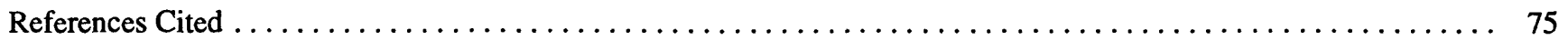

Figures

1. Sketch showing typical occurrences of ground water in the Hawaiian Islands $\ldots \ldots \ldots \ldots \ldots \ldots \ldots \ldots$

2-9. Maps of Oahu showing:

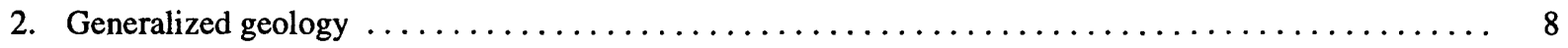

3. Water levels and generalized directions of ground-water flow $\ldots \ldots \ldots \ldots \ldots \ldots \ldots \ldots \ldots \ldots$

4. Principal ground-water areas and type of ground-water occurrence $\ldots \ldots \ldots \ldots \ldots \ldots \ldots \ldots \ldots \ldots$

5. Wells where water-level data were collected as part of the U.S. Geological Survey ground-water

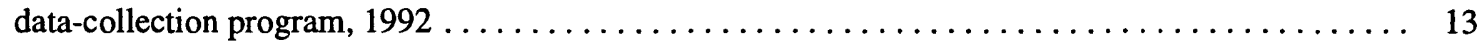

6. Wells where water-quality data were collected as part of the U.S. Geological Survey ground-water data-collection program, $1992 \ldots \ldots \ldots \ldots \ldots \ldots \ldots \ldots \ldots \ldots \ldots \ldots \ldots \ldots$

7. Selected wells in the Board of Water Supply and Commission on Water Resource Management

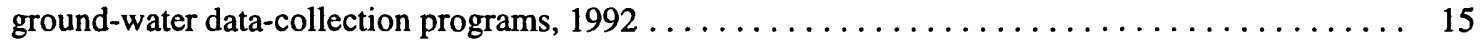

8. Distribution and magnitude of ground-water pumpage, $1990 \ldots \ldots \ldots \ldots \ldots \ldots \ldots \ldots \ldots \ldots$

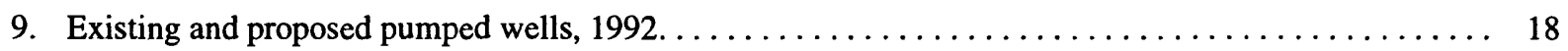

10. Chart listing water-management network wells and number of additional locations needed, Oahu ...... 19

11-12. Maps of Oahu showing:

11. Water-level data-collection sites (1992) classified as water-management wells and locations where additional wells are needed for water-level data

12. Chloride-concentration data-collection sites (1992) classified as water-management wells and locations where additional wells are needed for chloride-concentration data 
13-17. Maps of Kauai showing:

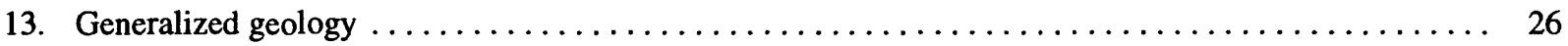

14. Wells where water-level data were collected as part of the U.S. Geological Survey ground-water

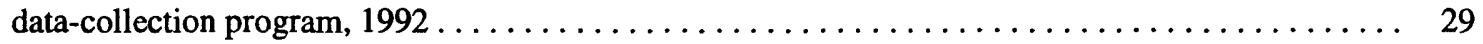

15. Wells where water-quality data were collected as part of the U.S. Geological Survey ground-

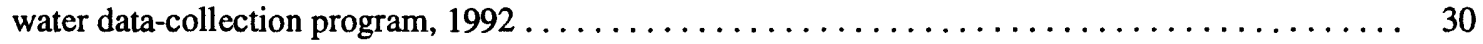

16. Distribution and magnitude of ground-water pumpage, $1992 \ldots \ldots \ldots \ldots \ldots \ldots \ldots \ldots \ldots \ldots \ldots$

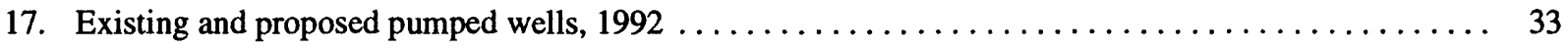

18. Chart listing water-management network wells and number of additional locations needed, Kauai. ...... 34

19-20. Maps of Kauai showing:

19. Water-level data-collection sites (1992) classified as water-management wells and locations where

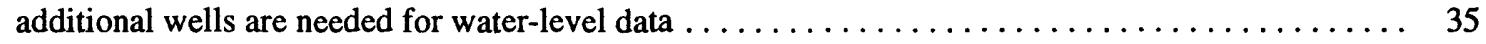

20. Chloride-concentration data-collection sites (1992) classified as water-management wells and locations where additional wells are needed for chloride-concentration data $\ldots \ldots \ldots \ldots \ldots \ldots$

21-25. Maps of Maui showing:

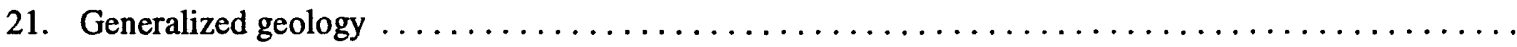

22. Wells where water-level data were collected as part of the U.S. Geological Survey ground-water

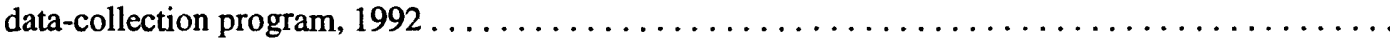

23. Wells where water-quality data were collected as part of the U.S. Geological Survey ground-

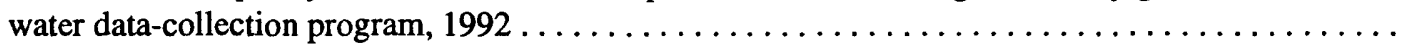

24. Distribution and magnitude of ground-water pumpage, $1992 \ldots \ldots \ldots \ldots \ldots \ldots \ldots \ldots \ldots \ldots$

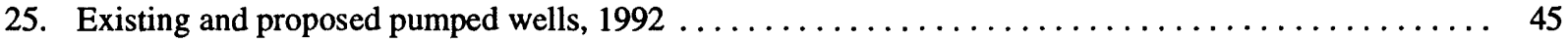

26. Chart listing water-management network wells and number of additional locations needed, Maui ...... 46

27-28. Maps of Maui showing:

27. Water-level data-collection sites (1992) classified as water-management wells and locations where

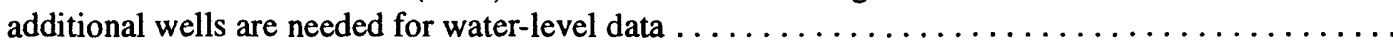

28. Chloride-concentration data-collection sites (1992) classified as water-management wells and locations where additional wells are needed for chloride-concentration data . . . . . . . . . . . . .

29-32. Maps of Molokai showing:

29. Generalized geology

30. Wells where water-level and water-quality data were collected as part of the U.S. Geological Survey

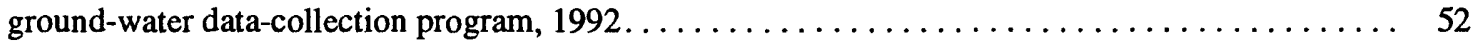

31. Distribution and magnitude of ground-water pumpage, $1992 \ldots \ldots \ldots \ldots \ldots \ldots \ldots \ldots \ldots \ldots \ldots$

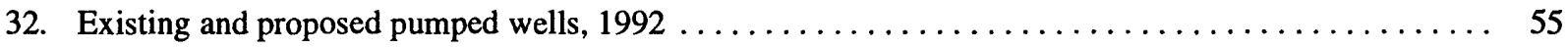

33. Chart listing water-management network wells and number of additional locations needed, Molokai. ..... 56

\section{4-35. Maps of Molokai showing:}

34. Water-level data-collection sites (1992) classified as water-management wells and locations where additional wells are needed for water-level data $\ldots \ldots \ldots \ldots \ldots \ldots \ldots \ldots \ldots \ldots \ldots \ldots \ldots$

35. Chloride-concentration sites (1992) classified as water-management wells and locations where additional wells are needed for chloride-concentration data . . . . . . . . . . . . . . . . . . 
36-40. Maps of the island of Hawaii showing:

36. Generalized geology

37. Wells where water-level data were collected as part of the U.S. Geological Survey ground-water

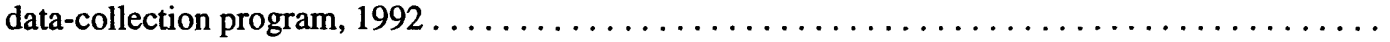

38. Wells where water-quality data were collected as part of the U.S. Geological Survey ground-

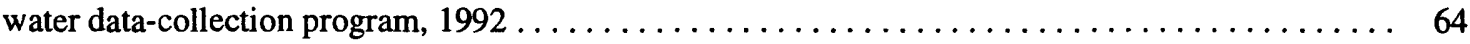

39. Distribution and magnitude of ground-water pumpage, $1992 \ldots \ldots \ldots \ldots \ldots \ldots \ldots \ldots \ldots \ldots \ldots$

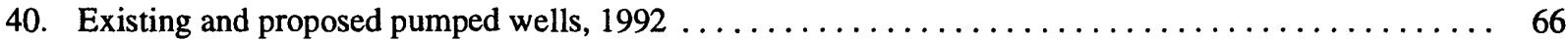

41. Chart listing water-management network wells and number of additional locations needed, island

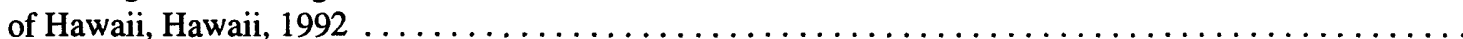

42-43. Maps of the island of Hawaii showing:

42. Water-level data-collection sites (1992) classified as water-management wells and locations where additional wells are needed for water-level data $\ldots \ldots \ldots \ldots \ldots \ldots \ldots \ldots \ldots \ldots \ldots \ldots \ldots \ldots$

43. Chloride-concentration data-collection sites (1992) classified as water-management wells and locations where additional wells are needed for chloride-concentration data . . . . . . . . . . . .

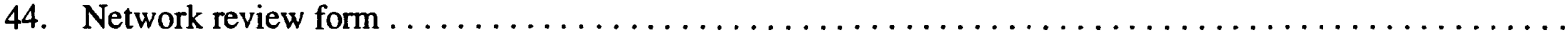

Tables

1. Summary of observation-well networks

2. Selected physical attributes and period of record for wells in the U.S. Geological Survey ground-water data-collection program, Oahu, Hawaii, 1992.

3. Selected physical attributes and period of record for wells in the U.S. Geological Survey ground-water data-collection program, Kauai, Hawaii, 1992.

4. Selected physical attributes and period of record for wells in the U.S. Geological Survey ground-water data-collection program, Maui, Hawaii, 1992

5. Selected physical attributes and period of record for wells in the U.S. Geological Survey ground-water

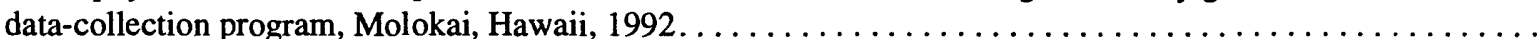

6. Selected physical attributes and period of record for wells in the U.S. Geological Survey ground-water data-collection program on the island of Hawaii, Hawaii, 1992 . 


\title{
Evaluation of the U.S. Geological Survey Ground-Water Data-Collection Program in Hawaii, 1992
}

\author{
By Stephen S. Anthony
}

\section{Abstract}

In 1992, the U.S. Geological Survey groundwater data-collection program in the State of Hawaii consisted of 188 wells distributed among the islands of Oahu, Kauai, Maui, Molokai, and Hawaii. Water-level and water-quality (temperature, specific conductance, and chloride concentration) data were collected from observation wells, deep monitoring wells that penetrate the zone of transition between freshwater and saltwater, freeflowing wells, and pumped wells. The objective of the program was to collect sufficient spatial and temporal data to define seasonal and long-term changes in ground-water levels and chloride concentrations induced by natural and human-made stresses for different climatic and hydrogeologic settings. Wells needed to meet this objective can be divided into two types of networks: (1) a watermanagement network to determine the response of ground-water flow systems to human-induced stresses, such as pumpage, and (2) a baseline network to determine the response of ground-water flow systems to natural stresses for different climatic and hydrogeologic settings. Maps showing the distribution and magnitude of pumpage and the distribution of proposed pumped wells are presented to identify areas in need of water-management networks. Wells in the 1992 U.S. Geological Survey ground-water data-collection program were classified as either water-management or baseline network wells. In addition, locations where additional water-management network wells are needed for water-level and water-quality data were identified.

\section{INTRODUCTION}

The U.S. Geological Survey (USGS) has been collecting ground-water data in Hawaii since the early 1900 's. The first systematic ground-water data-collection program in Hawaii was designed to estimate the amount of water discharging from artesian wells on the island of Oahu, and where possible, to collect waterlevel and chloride-concentration data from these wells (K.J. Takasaki, USGS, oral commun., 1992). The program resulted in monthly water-level and chloride-concentration data from more than 100 wells for the period 1923 through 1970.

The existing USGS ground-water data-collection program in Hawaii was established in 1972 to document baseline ground-water conditions on the major Hawaiian islands of Oahu, Kauai, Maui, Molokai, and Hawaii. The program began with a field inventory of about 600 wells and selection of about 170 wells where existing knowledge of geologic and hydrologic conditions indicated a need for more detailed water-level and chlorideconcentration data. The distribution of wells and the type of data collected occasionally have been adjusted to improve coverage, to take advantage of new wells constructed, and to replace wells destroyed or lost. The program is operated and maintained by the USGS in cooperation with the State of Hawaii, Department of Land and Natural Resources, Commission on Water Resource Management (CWRM) and consisted of 188 wells in 1992.

Decisions related to ground-water use and development in Hawaii are the responsibility of the CWRM. These decisions depend on accurate spatial and temporal hydrologic data. As a result, the CWRM and the USGS have undertaken a study to evaluate the usefulness and effectiveness of the USGS ground-water datacollection program. To evaluate the program, the objec- 
tives and the wells needed to meet these objectives need to be identified. Once this is accomplished, it is then possible to determine which wells in the program are providing useful data and where additional wells are needed for water-level and chloride-concentration data.

This report describes an evaluation of the 1992 USGS ground-water data-collection program in Hawaii. The occurrence of ground water in the Hawaiian islands is briefly described. Objectives for the datacollection program are identified followed by a description of well networks needed to prepare maps of water levels and chloride concentrations. For the islands of Oahu, Kauai, Maui, Molokai, and Hawaii, the wells in the 1992 ground-water data-collection program are described followed by maps showing the distribution and magnitude of pumpage, and the distribution of proposed pumped wells. Wells in the 1992 USGS groundwater data-collection program that provide useful data for mapping water levels and chloride concentrations are identified followed by locations where additional wells are needed for water-level and chloride-concentration data. In addition, a procedure to store and review data is described.

\section{OCCURRENCE OF GROUND WATER}

The occurrence of fresh ground water in the Hawaiian islands is determined by the rate of recharge from rainfall and by the permeability of the rocks and sediments. The permeability of Hawaiian lava flows is highly variable and mainly dependent on the individual lava-flow thickness. Where lava flows are thin (less than $10 \mathrm{ft}$ ), such as on the flanks of the volcanoes, they are extremely permeable owing to a large percentage of inter- and intraflow void space through which ground water can move. Thick lava flows (greater than $30 \mathrm{ft}$ ) have less void space and their permeability may be as much as two to three orders of magnitude lower than in thin lava flows. Thick lava flows commonly form when a new lava flow fills a pre-existing depressional feature such as a caldera, a stream valley, or a coastal embayment.

Ground water in Hawaii occurs in two modes. Basal water, which refers to a body of freshwater floating on and displacing saltwater near sea level, is the most areally extensive form of ground water in Hawaii. High-level water is less common and is either impounded within compartments formed by relatively less permeable dikes or perched on low-permeability layers such as ash beds, buried soil horizons, and dense lava flows. In general, ground water flows from the dike-impounded water bodies located near the crests of the mountains into streams, springs, and the basal-water body before discharging to the ocean. A generalized hydrogeologic section illustrates the relation between modes of ground-water occurrence in Hawaii (fig. 1).

Basal water typically occurs in highly permeable lava flows or to a lesser extent in low-permeability sedimentary deposits near the shore. The water table of basal-water bodies typically has a head of less than $3 \mathrm{ft}$ above sea level at the shore, rising inland at about 1 $\mathrm{ft} / \mathrm{mi}$ (Hunt and others, 1988). Because of density differences between freshwater and saltwater, freshwater extends to depths below mean sea level of about 40 times the altitude of the water table. This is referred to as the Ghyben-Herzberg relation (Bear, 1979). The change from freshwater to saltwater is gradual through a zone of transition between freshwater and saltwater. In some coastal areas where lava flows are thick, the permeability of the rocks is much lower and the water table may rise to several hundred feet above sea level. The vertical extent of freshwater below sea level in these areas may not be controlled by the GhybenHerzberg relation. Thick basal-water bodies also are formed where low-permeability sedimentary deposits, called caprock in Hawaii, retard the discharge of ground water at the coast. The occurrence of a caprock at the coast results in a confined basal-water body beneath the caprock and an unconfined basal-water body inland of the caprock where the water table is a few feet higher than it would be if the caprock were absent.

Dug wells, Maui-type wells (horizontal infiltration galleries), and drilled wells are used to develop basal water. Most of the shallow dug wells develop water from the caprock found along the shore, but some penetrate the underlying volcanic rocks. Maui-type wells are dug to, or slightly below sea level, with one or more tunnels extending outward to skim freshwater from the surface of the basal-water body. Drilled wells, located inland of the dug and Maui-type wells at altitudes typically less than $1,000 \mathrm{ft}$, are used to develop potable water supplies. When water is pumped from one of these wells, the lowering of water levels associated with pumping cause a local rise in the saltwater beneath the well. As a result, the chloride concentration of the pumped water is a constraint on the availability of freshwater from wells in a basal-water body. 


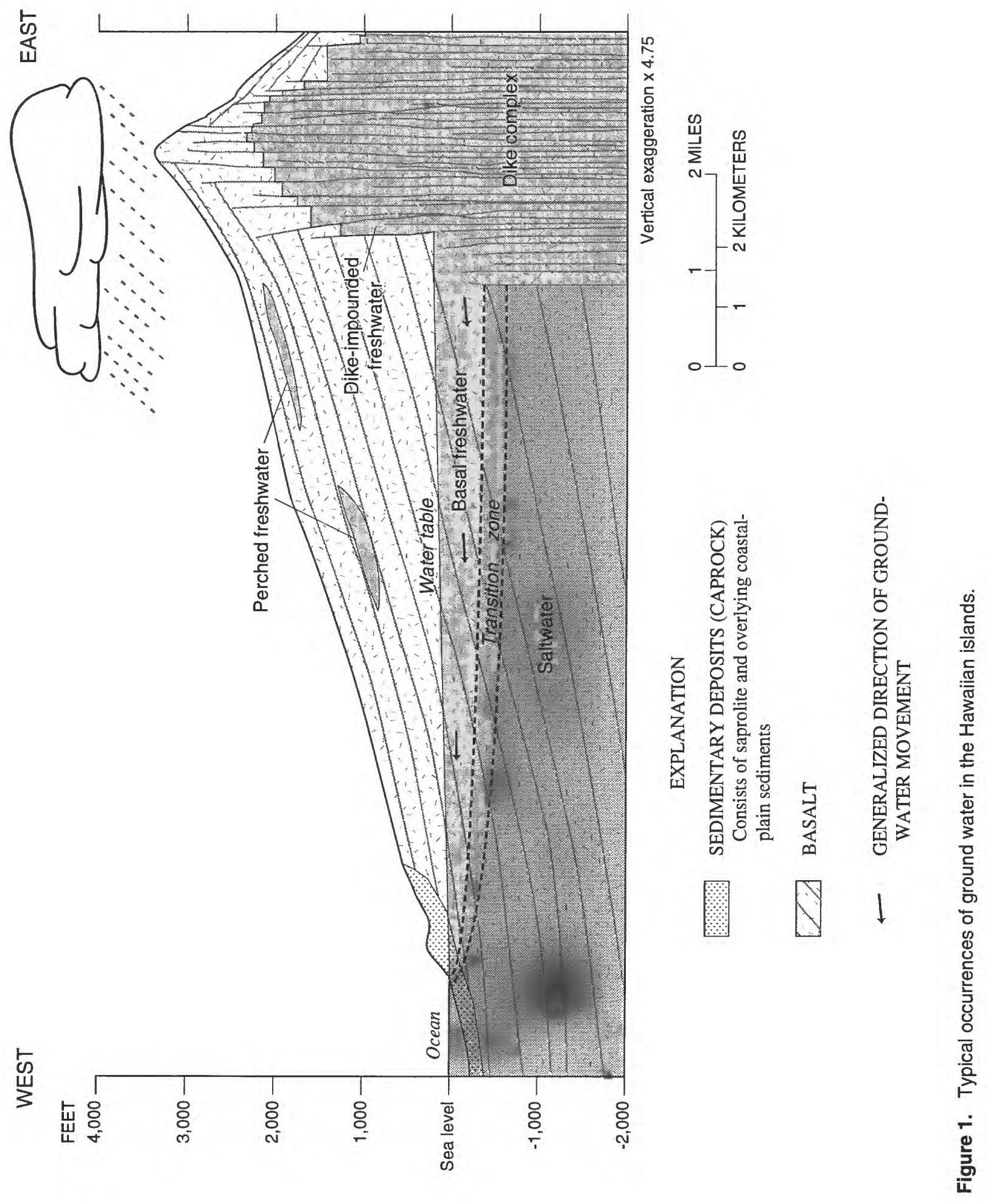


The nearly vertical dikes in the rift zones of Hawaiian volcanoes retard the flow of ground water, resulting in water levels significantly above sea level. Rainwater infiltrates into the lavas between the dikes and continues to accumulate until the flow through the dikes equals the amount of infiltrating rainwater. Dikeimpounded water may not float on saltwater as does basal water, but could simply be held up by denser intrusive rock beneath (Takasaki and Mink, 1985). Water discharges from dike compartments through joints and gaps in the dikes and where impounded water overtops dikes (Takasaki and Mink, 1985). Development of dike-impounded water consists of: (1) simple diversions of water from springs and spring-fed streams which are supplied by dike-impounded water, (2) tunnels that penetrate dikes impounding water, and (3) drilled wells that penetrate dike-intruded lavas.

Water infiltrating downward through permeable lavas may become temporarily perched by less permeable layers. Perched-water bodies are separated from the basal-water body by a low-permeability layer and by an unsaturated zone above the basal-water body. These less-permeable layers may be denser lava flows or soil, but most are layers of ash as much as $2 \mathrm{ft}$ thick. Development of perched-water bodies has been primarily by tunnels that follow the perching layers. Flow from perched-water bodies tends to be relatively unstable owing to the limited areal extent of perching layers, small storage, and quick response to rainfall.

\section{OBJECTIVES OF THE GROUND-WATER DATA-COLLECTION PROGRAM}

Ground-water data-collection programs need to be designed and implemented with specific objectives so that meaningful data are collected. As part of this study, the USGS, in cooperation with the CWRM, identified the following objectives for the USGS ground-water data-collection program in Hawaii. The 1992 USGS ground-water data collection program is evaluated with regard to these objectives, which are to collect sufficient spatial and temporal data to:

1. Define seasonal and long-term changes in groundwater levels and chloride concentrations induced by human-made stresses such as pumpage.
2. Define seasonal and long-term variations in groundwater levels and chloride concentrations induced by natural stresses for different climatic, and hydrogeologic settings.

Wells needed to meet these objectives can be divided into two types of networks: (1) a water-management network to determine the response of groundwater flow systems to human-induced stresses, such as pumpage, and (2) a baseline network to determine the response of ground-water flow systems to natural stresses for different climatic and hydrogeologic settings (table 1). An analysis of the water-level and chloride-concentration data collected from these networks will provide information on: (1) the extent of aquifers, (2) changes in ground-water storage, and (3) the degree of confinement by considering the effect of precipitation, oceanic tides, and barometric pressure on groundwater levels. In addition, the data will provide information for the calibration and verification of ground-water flow models, and the design and management of ground-water withdrawal and waste disposal systems. The water-management and baseline network concept presented in this report was modified from the work of Heath (1976) and Reilly (1993).

\section{Water-Management Network}

Wells in a water-management network are used to determine the response of ground-water flow systems to human-induced stresses such as pumpage. The waterlevel and chloride-concentration data collected from water-management wells are needed for estimating ground-water availability and identifying overdevelopment. Water-management networks ideally consist of observation wells randomly spaced over an area of interest. The number of wells needed depends on the hydrogeologic framework of the ground-water flow system, the number and magnitude of human-induced stresses, and the level of detail needed. Water-management networks are most easily applied to thin basalwater bodies where the dominant ground-water flow direction is horizontal.

Water-level data collected from wells in a watermanagement network can be used to determine the extent of aquifers and changes in ground-water storage by comparing water-table maps separated by significant periods of time, such as several years. The water-table maps being compared need to be constructed from 
Table 1. Summary of observation-well networks

[modified from Heath, 1976]

\begin{tabular}{|c|c|c|}
\hline Network & Objectives & Products \\
\hline \multirow[t]{4}{*}{ Water-management....... } & Define status of storage & Water-table maps \\
\hline & Define areal extent of aquifer & $\begin{array}{l}\text { Maps showing net change in water level or storage } \\
\text { over a selected period }\end{array}$ \\
\hline & & Graphs showing change in water levels with time \\
\hline & $\begin{array}{l}\text { Determine distribution of freshwater and the } \\
\text { zone of transition between freshwater and salt- } \\
\text { water }\end{array}$ & $\begin{array}{l}\text { Chloride-concentration maps } \\
\text { Graphs showing change in chloride concentrations } \\
\text { with time } \\
\text { Graphs showing chloride concentrations as a func- } \\
\text { tion of pumping rates }\end{array}$ \\
\hline Baseline ............. & $\begin{array}{l}\text { Define effect of climate on ground-water storage } \\
\text { Define effect of geology on climate response }\end{array}$ & $\begin{array}{l}\text { Hydrographs showing natural changes in storage for } \\
\text { different hydrogeologic settings in each climatic } \\
\text { zone }\end{array}$ \\
\hline
\end{tabular}

water-level data collected during a relatively short period of time, such as several months to avoid seasonal variations in water levels. Such maps are usually prepared for extensive basal-water bodies, such as the Pearl Harbor ground-water area on Oahu, that are either already heavily developed or are undergoing rapid development. The first time an area is mapped, it is desirable to obtain data from as many wells as possible that are open to the same aquifer or water-bearing zone. The location and depth of observation wells needed in a water-management network requires careful consideration if useful information is to be obtained from them. It is best if the wells are installed with short screens because this enables water-level and chloride-concentration data to be defined in three-dimensional space. In addition, the effect of oceanic tides and nearby pumped wells on water levels needs to be considered. In coastal locations where a basal-water body is confined by a low-permeability caprock, data needs to be collected from both the confined basal-water body and the overlying unconfined water body contained in the caprock. Vertical-flow gradients must also be defined in thick basal-water bodies where the water table is several hundred feet above sea level. This can be accomplished with clusters of observation wells penetrating various depths within the thick basal-water body. The configuration of the water table in thick basal-water bodies can be obtained from a network of observation wells drilled to the first occurrence of water in the hole. Network management will identify wells not needed in the preparation of subsequent maps and areas with an insufficient distribution of wells.
Chloride-concentration data collected from wells in a water-management network can be used to determine the areal and vertical distribution of fresh ground water. Pumped wells can be used to monitor the chloride concentration of water pumped from a well field. Because of differences in the rate of ground-water pumpage and well depth, however, data from pumped wells are difficult to interpret. For this reason, data from observation wells is preferred to data from pumped wells. Observation wells open to the producing zone and located at different distances from centers of pumping can be used to monitor the lateral movement of the saltwater into an area of freshwater. Deep monitoring wells can be used to define the vertical distribution of freshwater and zone of transition between freshwater and saltwater. In the vicinity of pumping centers, deep monitoring wells can be used to monitor the vertical movement of the zone of transition between freshwater and saltwater by comparing data separated by a significant period of time, such as a year or several years. If the zone of transition between freshwater and saltwater rises beneath a pumping center such that the chloride concentration of water produced becomes unacceptable, or nearly so, the rate of withdrawal from the pumping center can be reduced by either trial and error or by using numerical models to estimate pumping rates acceptable for producing the quality of water needed.

\section{Baseline Network}

Wells in a baseline network are located in areas not significantly affected by human-induced stresses. The 
water-level and chloride-concentration data collected from these wells can be used to determine the response of the ground-water flow system to variations in climate and hydrogeologic setting. This network would consist of (1) wells that show only the effect of spatial variations in climate on ground-water storage, and (2) wells that show how climatic effects are modified by different hydrogeologic settings. The baseline network also is needed in the interpretation of data from the water-management network.

\section{EVALUATION OF THE GROUND-WATER DATA-COLLECTION PROGRAM}

Decisions related to ground-water use and development in Hawaii are the responsibility of the CWRM. Of immediate concern to the CWRM are areas where proposed ground-water withdrawals may affect the availability of fresh ground water for existing groundwater withdrawals and/or instream uses of groundwater discharge in streams (R.M. Loui, Commission on Water Resource Management, oral commun., 1993). To meet this immediate concern, the scope of this evaluation is focused on: (1) identifying areas that need to be included in water-management networks, (2) identifying wells in the 1992 USGS ground-water data-collection program that need to be included in watermanagement networks, and (3) identifying locations where additional water-management wells are needed. As a result, the wells in the 1992 USGS ground-water data-collection program that were not classified as water-management wells have been classified as baseline wells; however, the historical data collected from these baseline wells have not been evaluated to determine which wells are providing useful data. The data storage and review process described in this report can be used to determine which baseline wells are providing useful data and where additional wells are needed for baseline data.

In 1992, the USGS ground-water data-collection program consisted of 188 wells distributed among the islands of Oahu, Kauai, Maui, Molokai, and Hawaii. Water-level and water-quality (temperature, specific conductance, and chloride concentration) data were collected from: (1) observation wells, (2) deep monitoring wells that penetrate the zone of transition between freshwater and saltwater, (3) free-flowing wells that penetrate a confined basal-water body, and (4) pumped wells. Most of the data collected as part of the program are published annually in the USGS Water-Data Report series (see, for example, Matsuoka and others, 1992). As part of this evaluation, the records of each well in the program were examined to determine: (1) the period of record of water-level and water-quality data, (2) if there is duplication of record from an adjacent well, (3) if the well is measured by well owner or another agency, and (4) if the well depth, and interval of the well open to aquifer material is known.

To identify areas in need of water-management networks, maps showing the distribution and magnitude of pumpage, and the distribution of proposed pumped wells were made. The distribution and magnitude of pumpage is based on a March 1993 compilation of wells with pumpage data reported to the CWRM (Richard Jeani, Commission on Water Resource Management, written commun., 1993). Well owners who pump more than $50,000 \mathrm{gal} / \mathrm{mo}$ are required to report pumpage data to the CWRM. Annual totals and daily averages of pumpage were computed for wells contained in this data set. The distribution of proposed pumped wells is based on a March 1993 compilation of wells for which well-construction or pump-installation permits have been issued by the CWRM (Ed Sakoda, Commission on Water Resource Management, written commun., 1993).

Areas that need to be included in water-management networks were determined by estimating the areal extent of the cone of depression resulting from major pumping centers. "Major," as used here, cannot be precisely defined but implies a rate of withdrawal large enough to produce measurable drawdowns in an area of at least several square miles (Heath, 1976). The areal extent of the cone of depression was estimated to encompass a radius equal to the distance from the major pumping center to the nearest discharge boundary, which was assumed to be the nearest shore. Owing to the expense of constructing observation wells, the inland boundary of a water-management network was limited to an altitude of less than $1,000 \mathrm{ft}$ for monitoring basal-water bodies which occur near sea level.

After defining the areas that needed to be included in water-management networks, the wells in the datacollection program were then classified as being in water-management or baseline networks. Because the distribution of wells in the data-collection program was not sufficient to meet the water-management network objectives, locations where additional water-manage- 
ment network wells are needed were identified. For each of these locations, however, it was beyond the scope of this study to determine if: (1) a well suitable for measurement already existed, (2) drilling an observation well was feasible, and (3) ground-water data collected by a well owner or another agency was sufficient for the purposes of the network. Where possible, however, a candidate well for each of the needed locations is identified.

\section{Oahu}

The island of Oahu is the highly dissected remnant of two shield volcanoes, the Waianae (older) and the Koolau (younger) (fig. 2). The original shield shapes of the volcanoes have eroded into two northwest-trending mountain ranges. Steeply dipping geohydrologic features, such as eruptive feeder dikes and weathered valley fills, impede ground-water flow causing abrupt discontinuities in the potentiometric surface across them (Stearns and Vaksvik, 1935). Within the mountain ranges, volcanic dikes impound ground water as much as $1,600 \mathrm{ft}$ above sea level. In the Schofield area of central Oahu, ground water is impounded to altitudes of $270 \mathrm{ft}$ or more in the Koolaú Basalt by subsurface structures of low permeability (fig. 3 ). The impounding structures are possibly dikes or buried weathered ridges of the Waianae Volcanics. Between prominent groundwater-flow barriers the potentiometric surface is smoothly continuous, and ground water occurs mainly as a freshwater lens floating on saltwater. Near the coast the volcanic aquifers are confined. Poorly permeable terrigenous sediments provide the confinement, but highly permeable limestones also are present. On the basis of water-level data shown in figure 3 , the island can be divided into 13 ground-water areas (fig. 4). Generalized ground-water flow directions are inferred from the water-level data (fig. 3).

In 1992, the USGS ground-water data-collection program on Oahu consisted of 23 observation wells, 11 free-flowing wells, and 25 pumped wells (table 2). Water levels were measured at about 9-week intervals in 17 of the observation wells, 4 of the free-flowing wells, and 3 of the pumped wells (fig. 5 and table 2). Continuous water levels were recorded in three of the observation wells (1959-05, 2153-05, and 2256-10) and one of the pumped wells (2901-07) (fig. 5 and table 2). Water-quality samples were collected at about 9-week intervals in 5 of the observation wells, all 11 of the free- flowing wells, and all 25 of the pumped wells (fig. 6 and table 2). Occasionally some of the pumped wells were not operating during a site visit. As a result, the record of water-quality data is incomplete for 8 of the 25 pumped wells in the program. Well depth is known for all of the wells in the program, except for wells 210303, 2809-06, 2901-07, and 2911-02.

In addition to the USGS, the CWRM and the City and County of Honolulu Board of Water Supply (BWS) maintain ground-water data-collection programs on Oahu. Water-level and water-quality (temperature, specific conductance, and chloride concentration) data collected by the CWRM are stored in a computerized database at the CWRM, while the data collected by the BWS currently are stored in log books at the BWS. The location of selected observation wells and deep monitoring wells in the 1992 CWRM and BWS groundwater data-collection programs are shown in figure 7 . Where appropriate, these wells were classified as watermanagement network wells. The pumped wells in the BWS program were not included in this evaluation because of the difficulty in interpreting pumping-well data. For example, many of the pumping-well sites in the BWS program represent batteries of several wells that penetrate different depths of the aquifer and that are pumped at different rates.

Ground-water pumpage on the island of Oahu was estimated to be between 300 and $400 \mathrm{Mgal} / \mathrm{d}$ for 1992 (Richard Jeani, Commission on Water Resource Management, oral commun., 1993). The actual rate is not known owing to incomplete reporting of pumpage data to the CWRM. The major users of ground water were the BWS, Oahu and Waialua sugar plantations, and the military. As of June 1994, the CWRM had issued a total of 614 ground-water use permits for the island of Oahu, totaling $427 \mathrm{Mgal} / \mathrm{d}$ (Roy Hardy, Commission on Water Resource Management, written commun., 1994). The demand for potable ground water on Oahu is projected to increase by about $57 \mathrm{Mgal} / \mathrm{d}$ by the year 2010 (State of Hawaii, Commission on Water Resource Management, 1992a). However, demand for ground water suitable for agriculture, landscaping, and golf courses is not projected to change by the year 2010 (State of Hawaii, Commission on Water Resource Management, 1992). Although the amount of acreage in diversified agriculture, landscaping, and golf courses is projected to increase, the overall irrigated acreage on Oahu is not expected to increase owing to a decline in sugarcane acreage. 


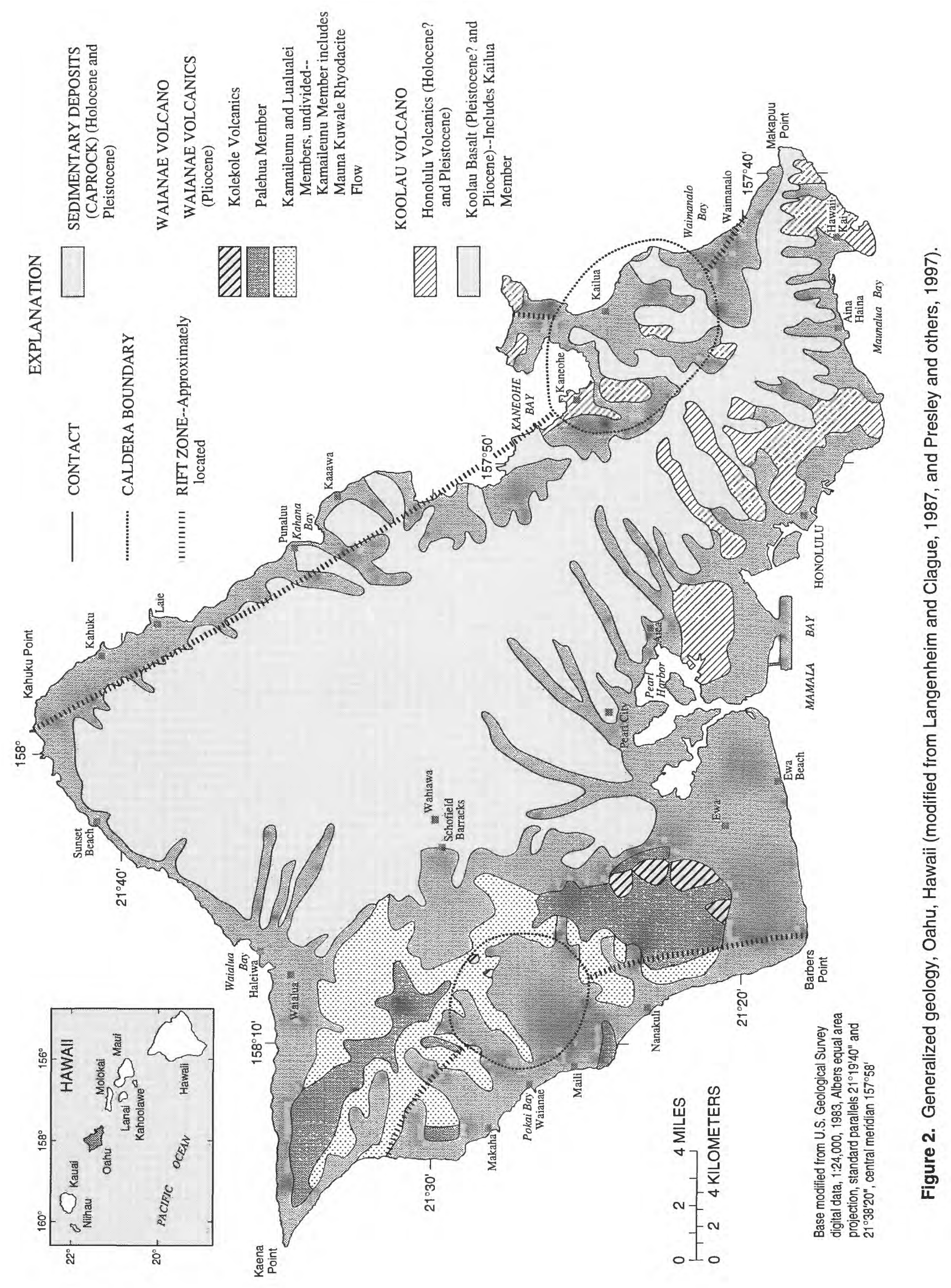



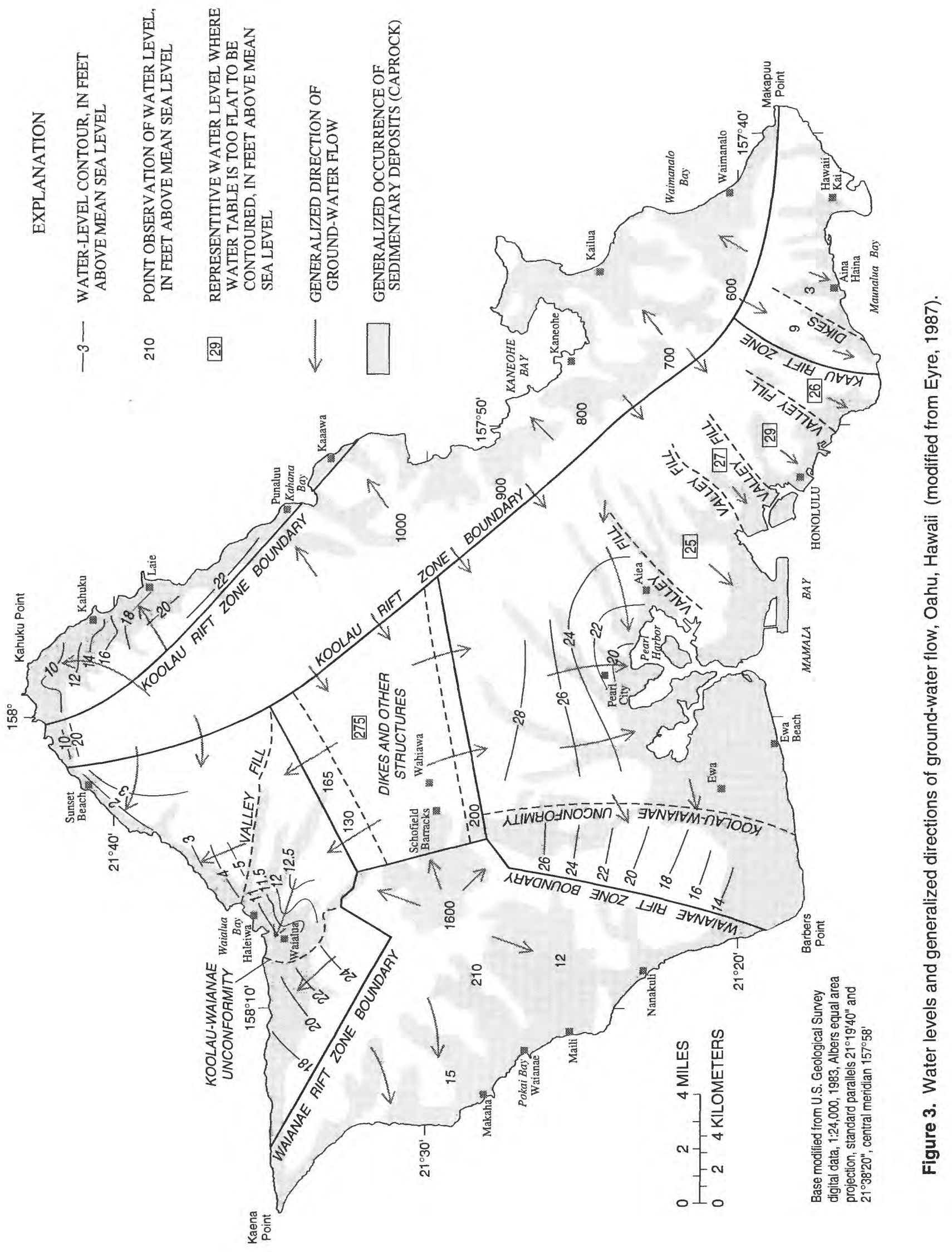

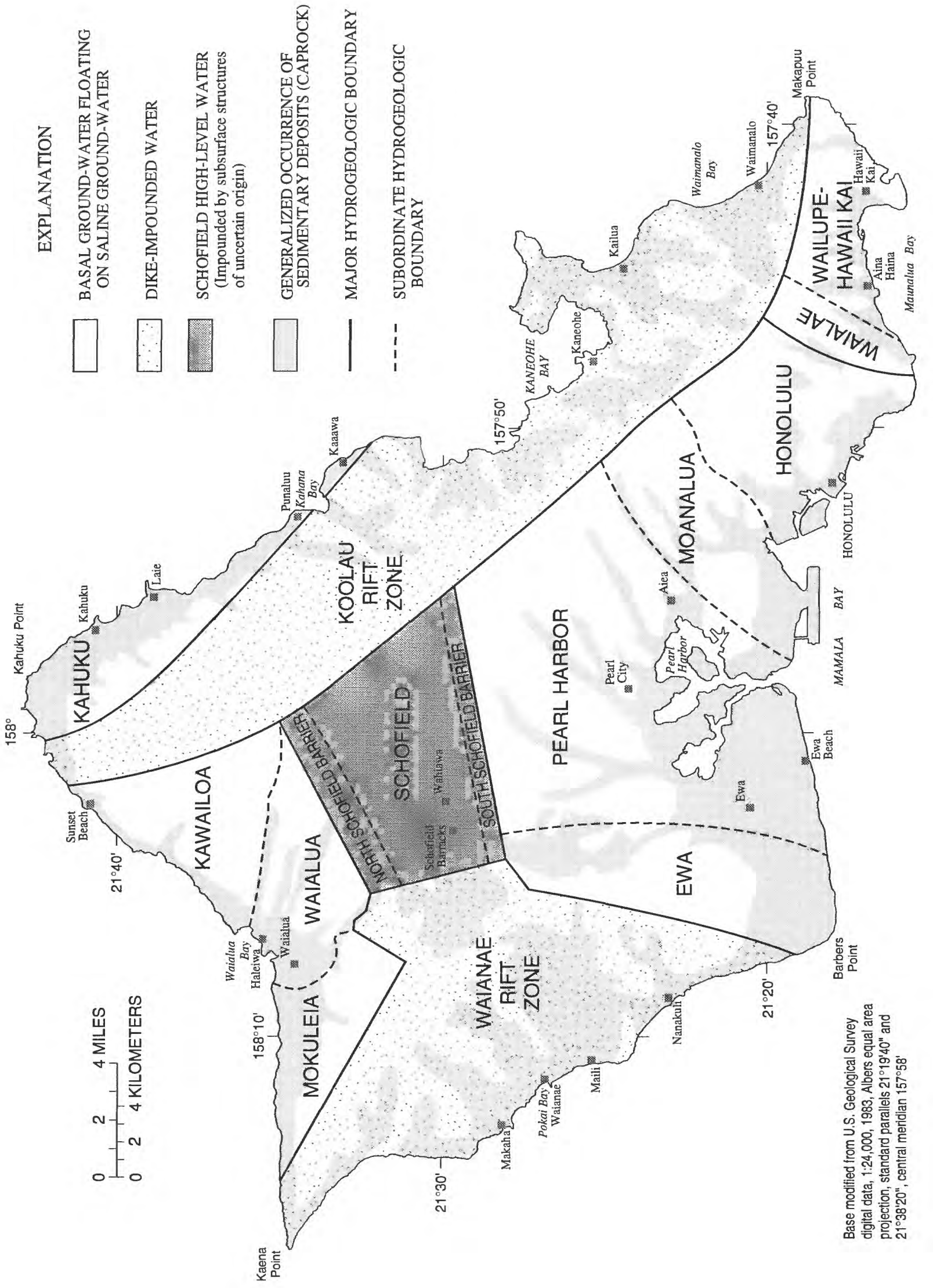

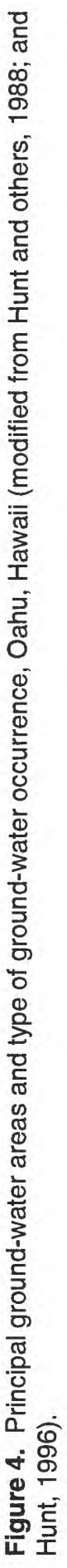




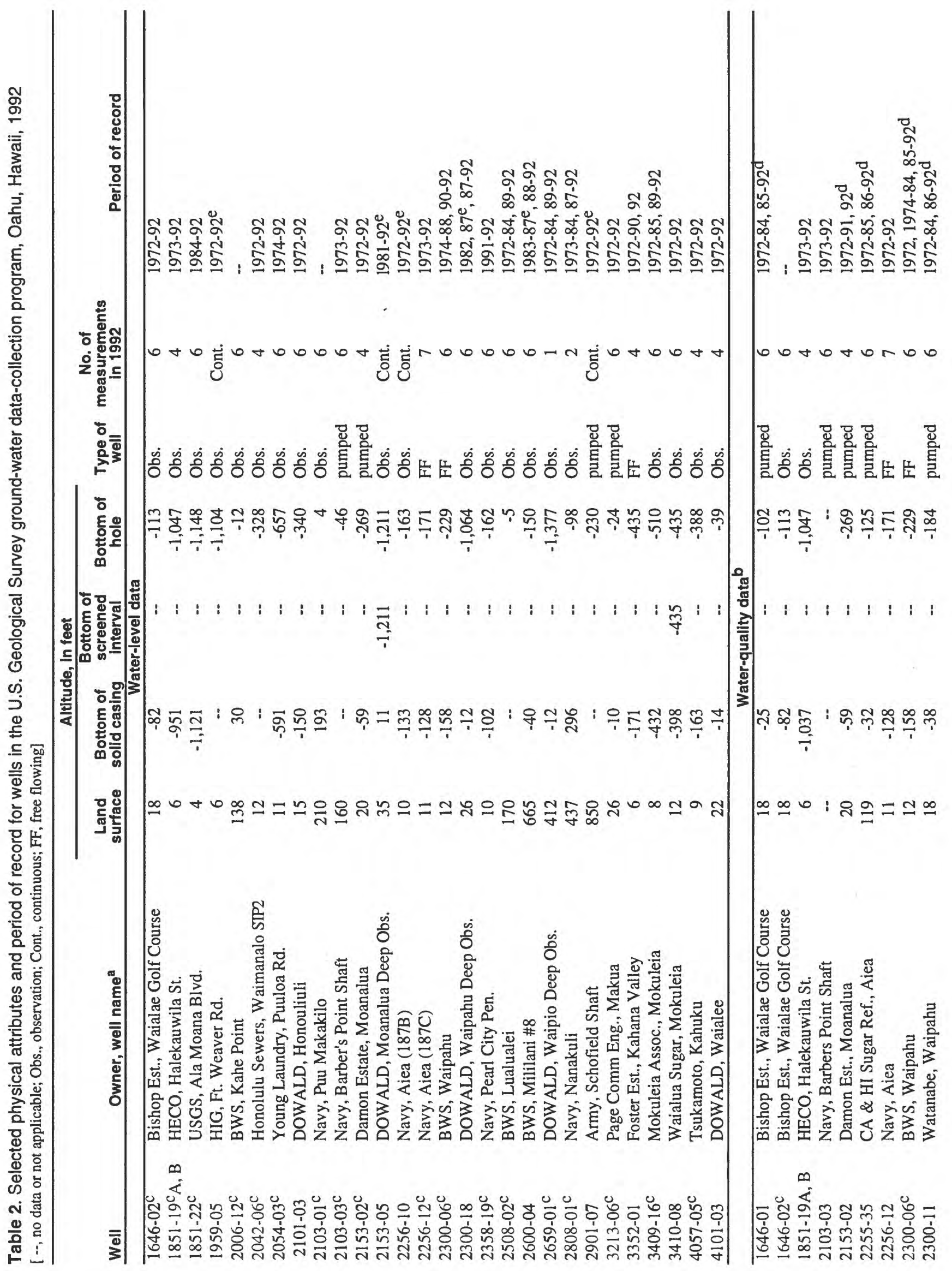




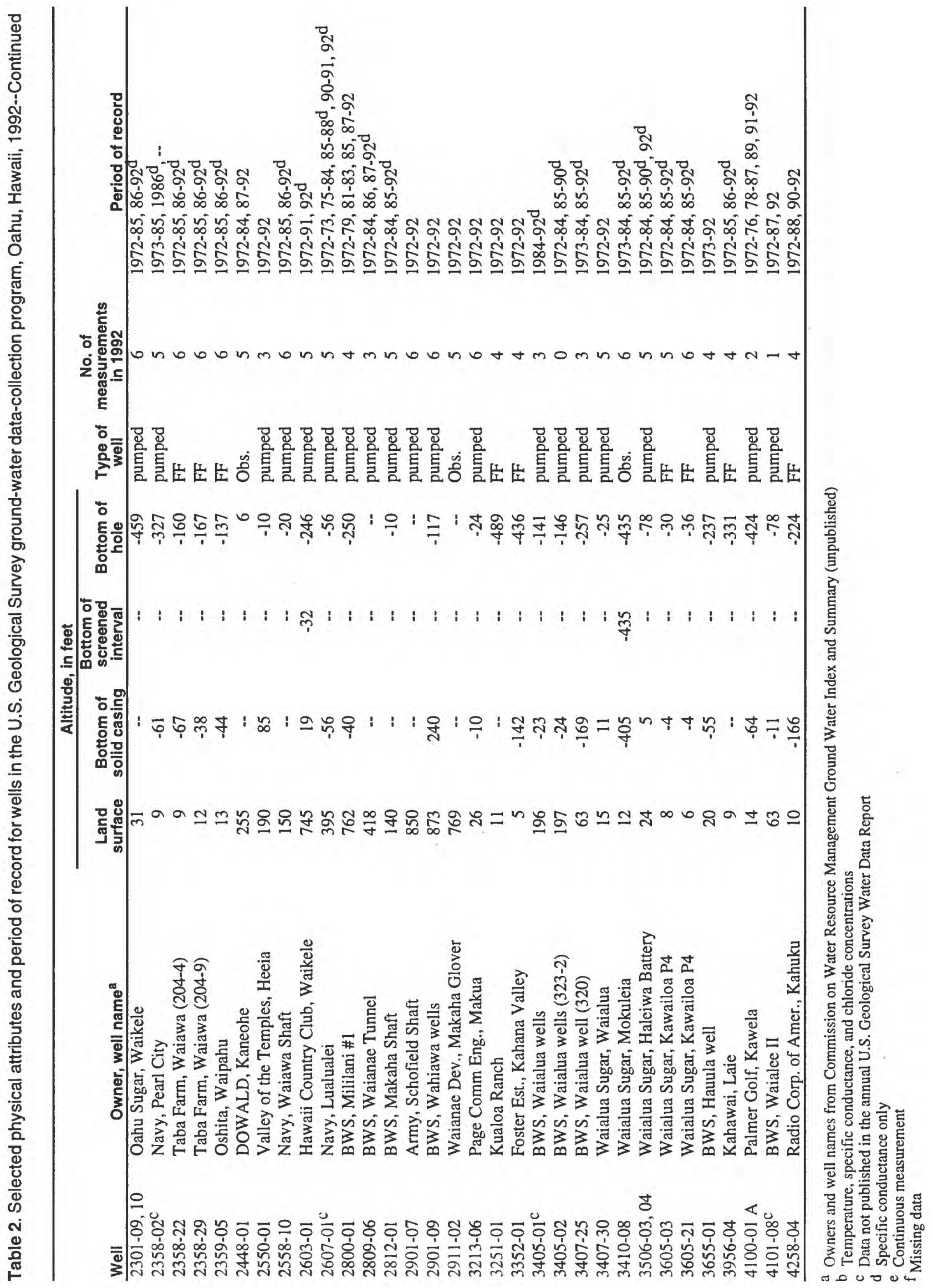



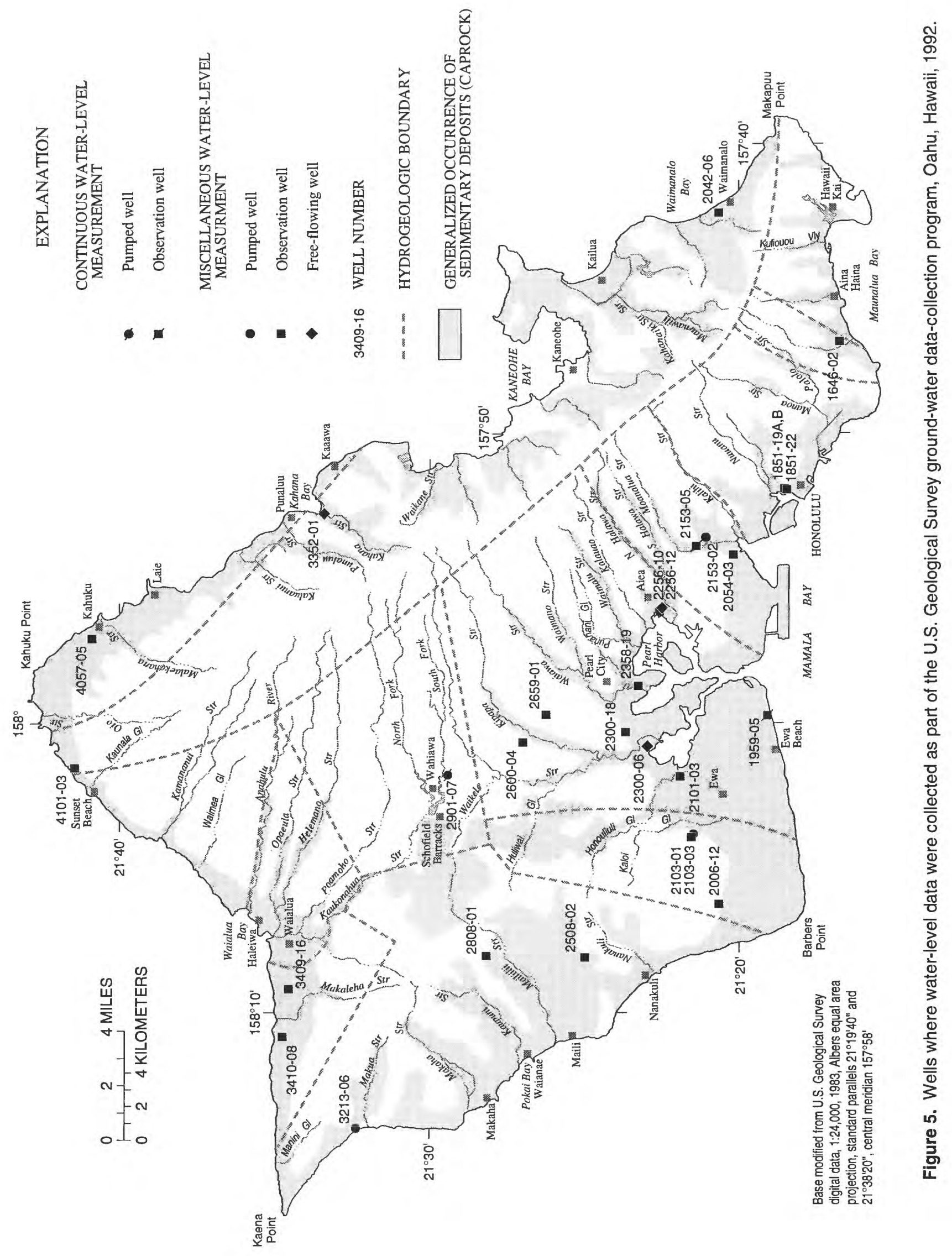

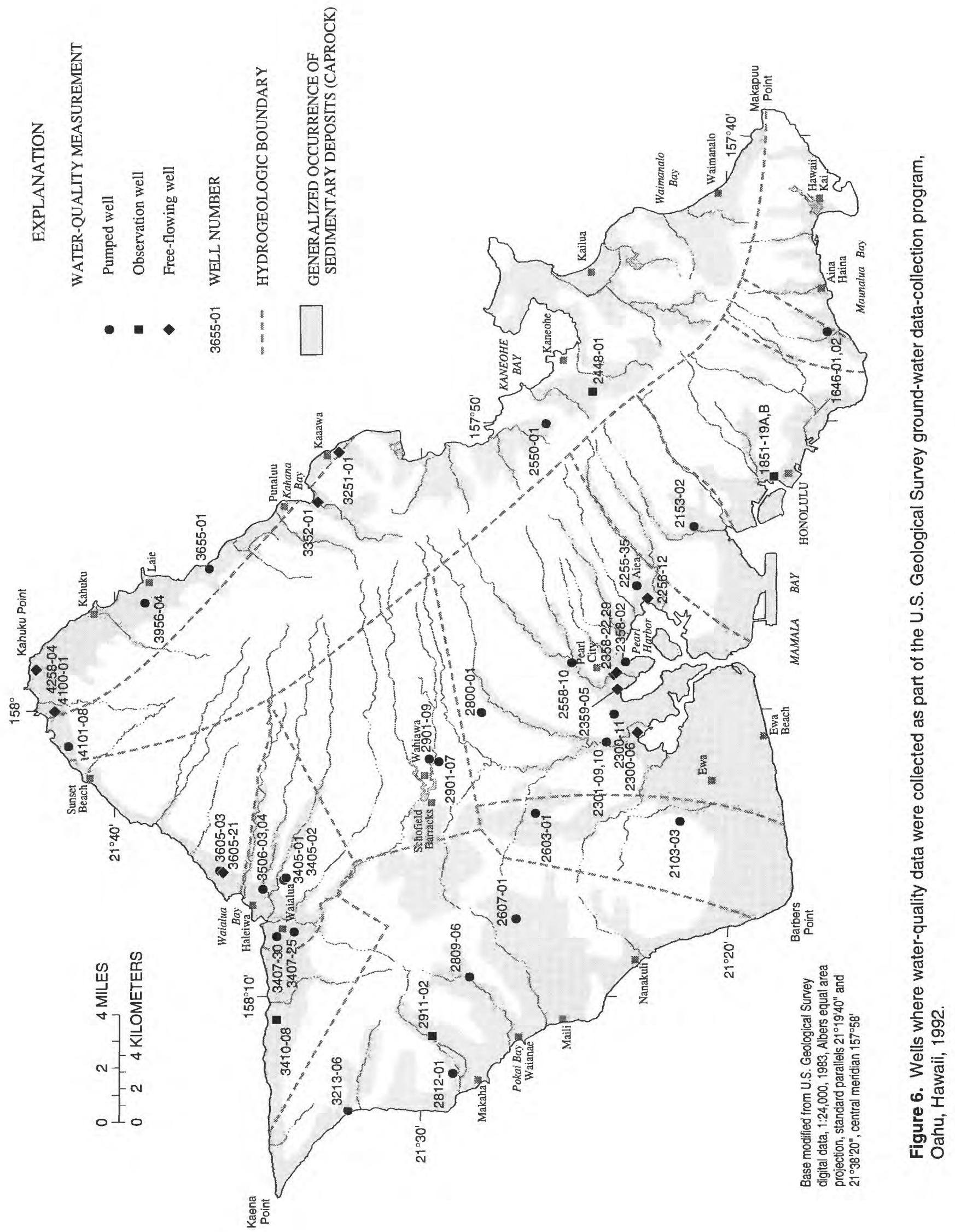

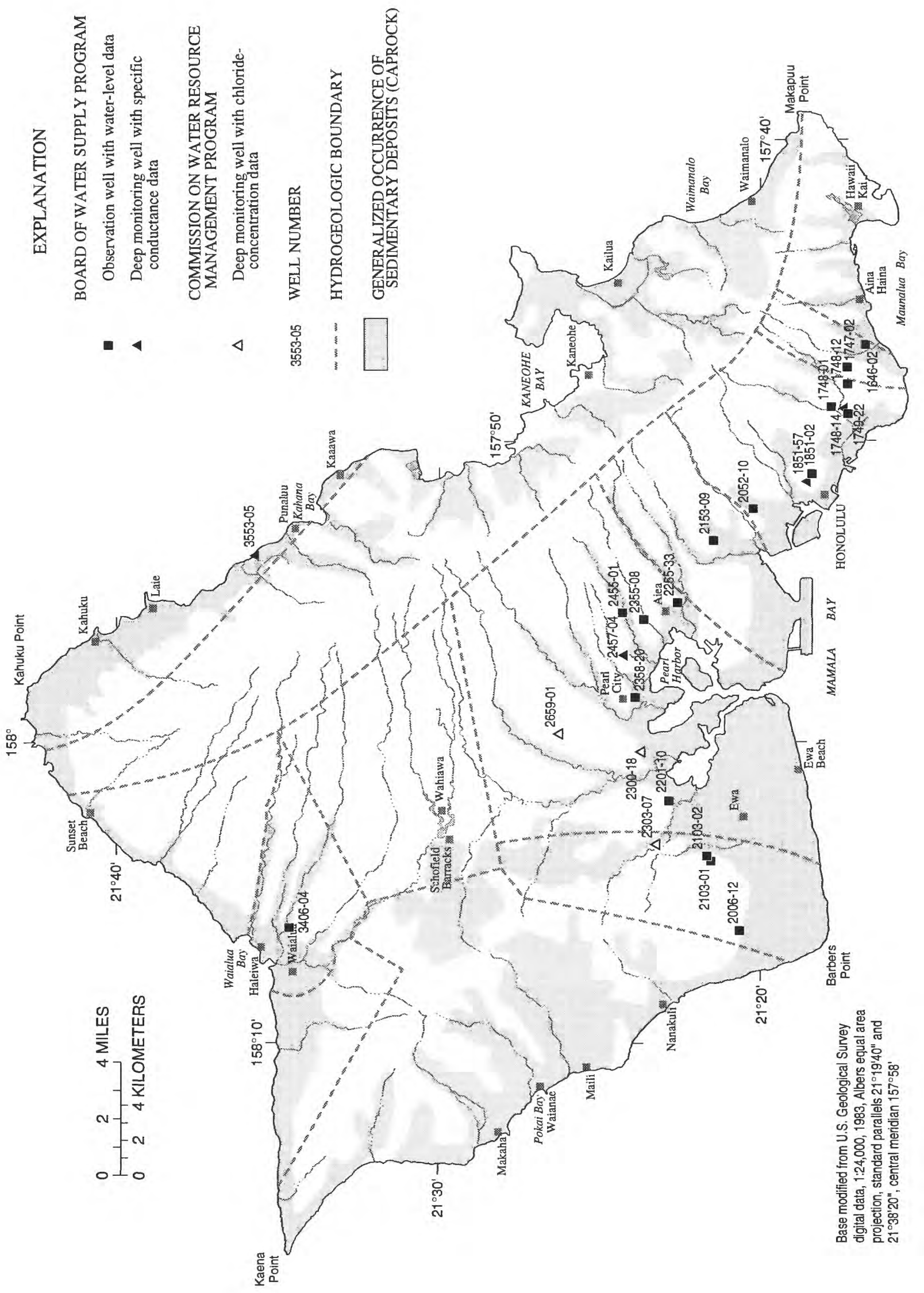

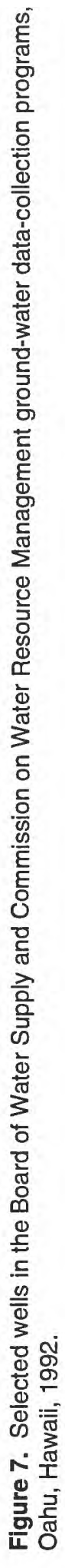


To identify areas in need of water-management networks, a map showing the distribution and magnitude of pumpage on the island of Oahu was generated from 1990 pumpage data reported to either the CWRM or the USGS. For 1990, the CWRM received data for 92 wells totaling $213 \mathrm{Mgal} / \mathrm{d}$ (Richard Jeani, Commission on Water Resource Management, written commun., 1993). As part of a Nationwide water-use study for 1990 , the USGS received data for 116 wells on the island of Oahu totaling $272 \mathrm{Mgal} / \mathrm{d}$ (P.J. Shade, U.S. Geological Survey, oral commun., 1994). Although neither the CWRM or USGS data set is complete, the combined data set represents the most complete information available and totals $305 \mathrm{Mgal} / \mathrm{d}$.

The distribution and magnitude of pumpage (fig. 8) and the distribution of proposed pumped wells (fig. 9) indicate a need for water-management networks in the Pearl Harbor, Moanalua, Honolulu, Ewa, and Waialua basal ground-water areas. In addition, a watermanagement network is needed in the Koolau rift zone to observe the effect of pumping dike-impounded water on ground-water levels and ground-water discharge to the streams in the area between Waikane and Kahanaiki Streams. Wells needed to meet the objectives of a water-management network in these areas are described below.

Pearl Harbor.--The Pearl Harbor ground-water area is located in a gently sloping plain between the northwest-southeast trending Koolau and Waianae mountain ranges. The Pearl Harbor area is bounded by valley-fill deposits of Halawa Stream to the east, the Koolau rift zone to the northeast, dikes or other structures of the Schofield high-level water body to the north, and the Koolau-Waianae unconformity to the west (fig. 3 and 4). In the Pearl Harbor area, a thick basal-water body occurs in the lavas of the Koolau Basalt owing to the occurrence of caprock at the coast (fig. 4). Wells in the basal-water body contained in the Koolau Basalt of the Pearl Harbor area have water levels that range from 20 to $28 \mathrm{ft}$ above mean sea level (fig. 3 ). Wells in the caprock have water levels less than $3 \mathrm{ft}$ above mean sea level.

The basal-water body in the Pearl Harbor area is the most heavily developed and studied ground-water body in Hawaii. Soroos and Ewart (1979) documented historical trends in water levels, chloride concentrations, and pumpage. Data from a number of observation wells indicate that water levels in the basal-water body have declined at a rate of about $0.1 \mathrm{ft} / \mathrm{yr}$ during the period 1910-77. Also during this period, pumpage increased from $104 \mathrm{Mgal} / \mathrm{d}$ to $240 \mathrm{Mgal} / \mathrm{d}$. Correspondingly, the discharge from springs along the coast has declined from $140 \mathrm{Mgal} / \mathrm{d}$ in 1910 to $50 \mathrm{Mgal} / \mathrm{d}$ in 1977 .

In 1979, concern over the continued availability of potable ground water from the area prompted the State of Hawaii to control the amount and location of groundwater withdrawals in the Pearl Harbor area. In 1990, pumpage from the area averaged $162 \mathrm{Mgal} / \mathrm{d}$ on the basis of data reported to either the CWRM or the USGS (fig. 8). Owing to rapid urban development, the demand for water in the area is increasing. In 1993, there were 28 proposed pumped wells in the area (fig. 9). Because all of the available ground-water resources in the area have been allocated by the CWRM, supplies for future development will have to come from the reallocation of existing sources of water, the development of additional sources outside of the Pearl Harbor area, or conservation and alternate water-development strategies (State of Hawaii, Commission on Water Resource Management, 1992a).

Water levels were measured by the USGS in seven observation wells and two free-flowing wells in the Pearl Harbor area in 1992 (fig. 5 and table 2). Continuous water levels were recorded in two of the observation wells (fig. 5 and table 2). In addition, the BWS collected water-level data from five observation wells in the area (fig. 7). All of these wells were classified as water-management network wells for the collection of water-level data (fig. 10); however, the distribution of wells (fig. 5) is not sufficient to contour water-level data. Locations where additional observation wells are needed for water-level data are shown in figure 11. An additional observation well (not shown in fig. 11) is needed at a few of the existing observation-well locations to monitor the occurrence and movement of ground water in both the caprock and the underlying Koolau Basalt. The additional observation wells will be needed in the caprock, because existing observation wells in the program are open only to the underlying Koolau Basalt. Candidate wells for inclusion in the water-management network are listed in figure 10.

Water-quality samples were collected by the USGS from six pumped wells and five free-flowing wells in the Pearl Harbor area in 1992 (fig. 6 and table 2). In addition, the BWS collected specific-conductance data from a deep monitoring well (2457-04) near Puna- 

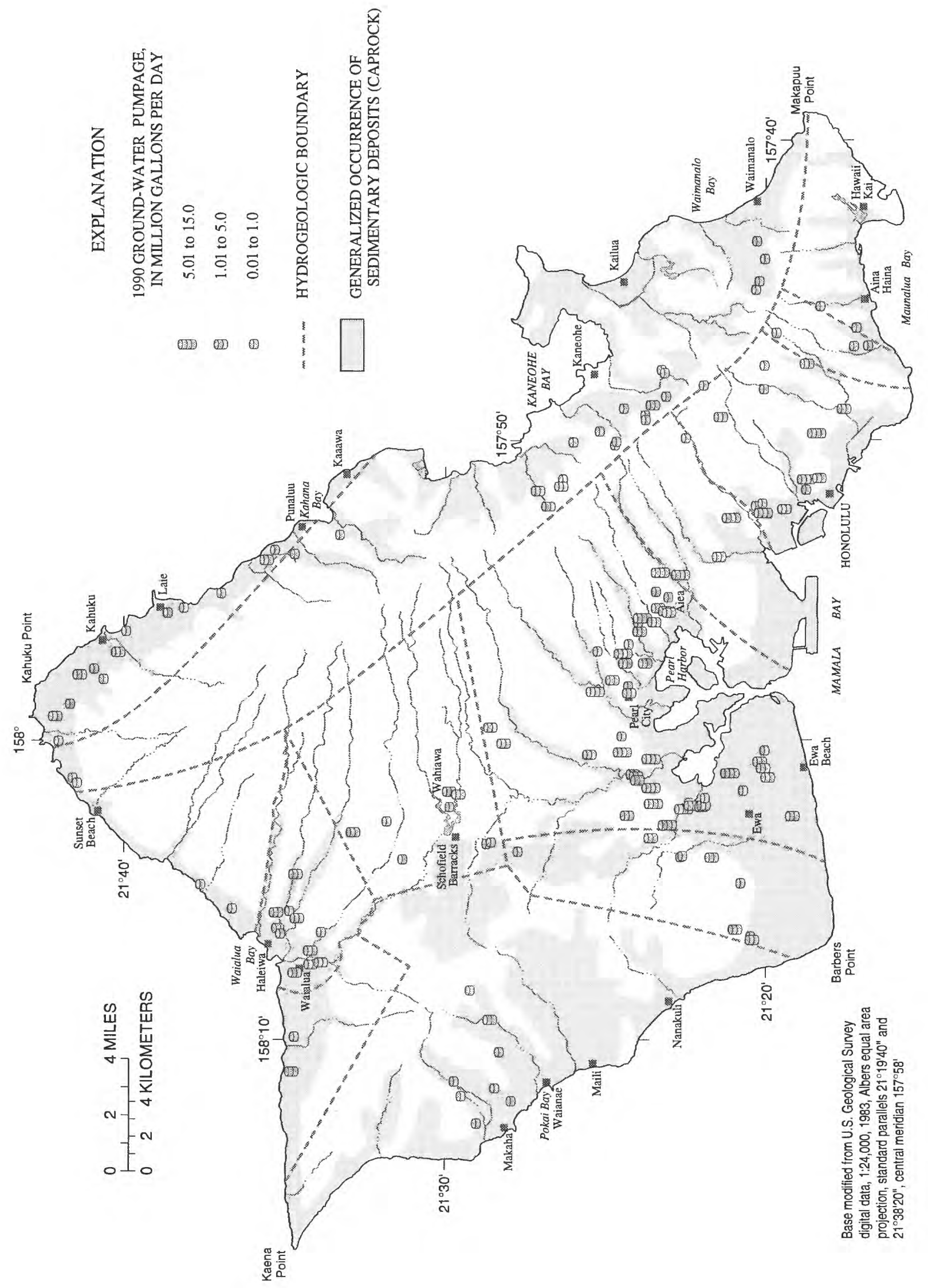

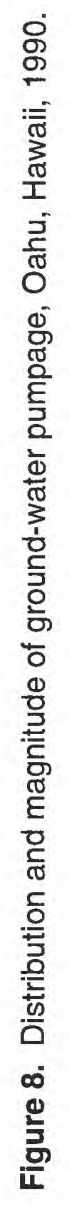




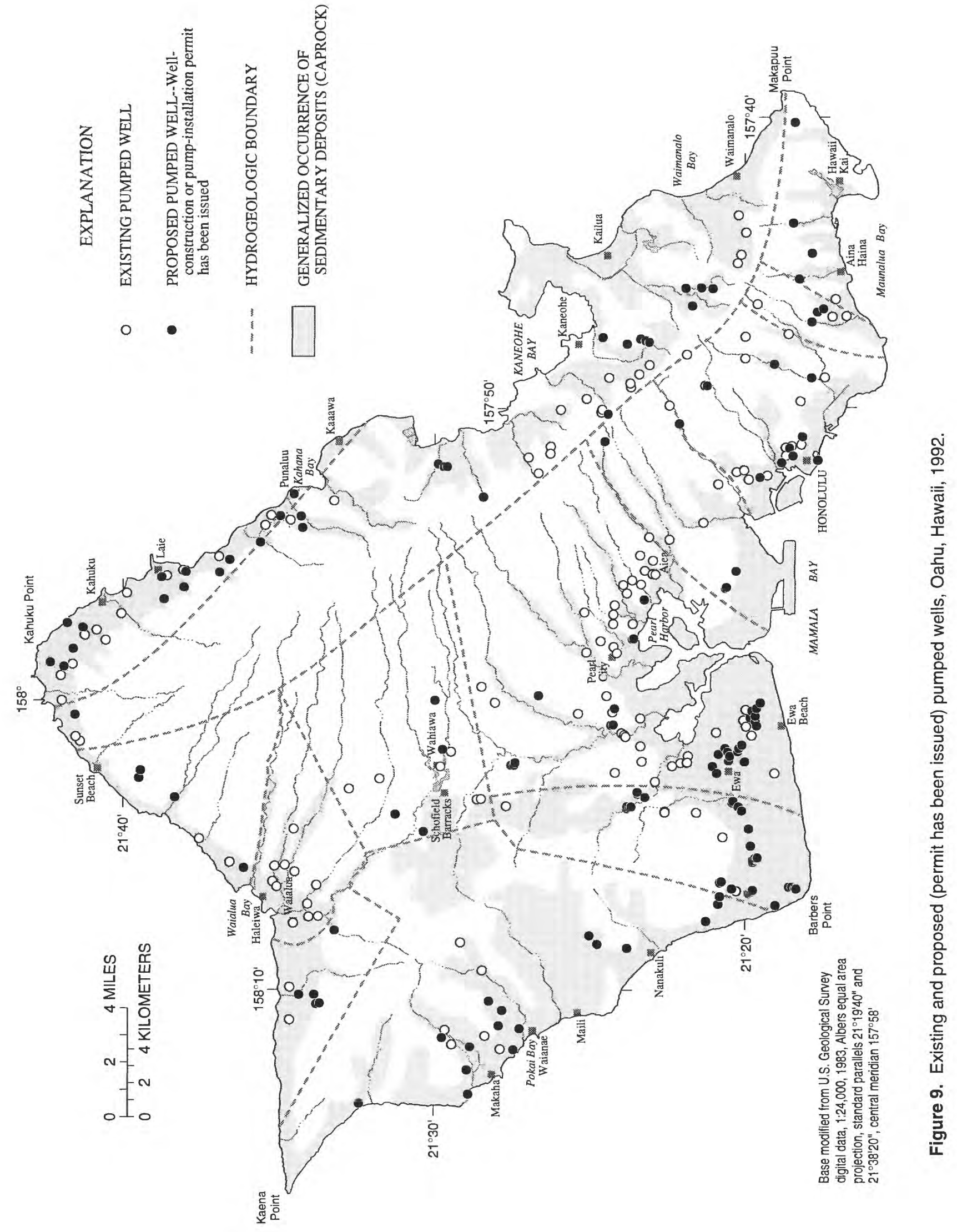




\begin{tabular}{|c|c|c|c|c|c|c|c|}
\hline \multirow[b]{2}{*}{$\begin{array}{c}\text { Type of } \\
\text { data collected }\end{array}$} & \multirow[b]{2}{*}{ Well type } & \multicolumn{4}{|c|}{$\begin{array}{c}1992 \text { GROUND-WATER DATA } \\
\text { COLLECTION PROGRAMS }\end{array}$} & \multicolumn{2}{|c|}{$\begin{array}{c}\text { ADDITIONAL } \\
\text { LOCATIONS NEEDED }\end{array}$} \\
\hline & & \multicolumn{2}{|c|}{ USGS } & BWS & CWRM & Candidate & $\begin{array}{l}\text { Total no } \\
\text { needed }\end{array}$ \\
\hline \multicolumn{8}{|c|}{ Pearl Harbor } \\
\hline Water level & Observation & $\begin{array}{l}1959-05 \\
2101-03 \\
2256-10 \\
2256-12^{\mathrm{a}} \\
2300-06^{\mathrm{a}}\end{array}$ & $\begin{array}{l}2300-18 \\
2358-19 \\
2600-04 \\
2659-01\end{array}$ & \begin{tabular}{|l|}
$2201-10$ \\
$2255-33$ \\
$2355-08$ \\
$2358-20$ \\
$2455-01$
\end{tabular} & & \begin{tabular}{|l|}
$2356-51$ \\
$2457-04$ \\
$2600-02$ \\
$2858-01$
\end{tabular} & 9 \\
\hline \multirow[t]{3}{*}{ Chloride } & Observation & $\begin{array}{l}2256-12^{\mathrm{a}} \\
2300-06^{\mathrm{a}} \\
2358-22^{\mathrm{a}} \\
2358-29^{\mathrm{a}} \\
2359-05^{\mathrm{a}}\end{array}$ & & & & \begin{tabular}{|l|}
$2101-03$ \\
$2356-51$ \\
$2455-01$ \\
$2600-02$ \\
$2858-01$ \\
\end{tabular} & 9 \\
\hline & $\begin{array}{l}\text { Deep } \\
\text { monitoring }\end{array}$ & & & $2457-04$ & $\begin{array}{l}2300-18 \\
2659-01\end{array}$ & $1951-05$ & 1 \\
\hline & Pumped & $\begin{array}{l}2255-35 \\
2300-11 \\
2301-09,10 \\
2358-02 \\
2558-10 \\
2800-01\end{array}$ & & & & & 0 \\
\hline \multicolumn{8}{|c|}{ Moanalua } \\
\hline Water level & Observation & \begin{tabular}{|l|}
$2054-03$ \\
$2153-02^{b}$ \\
$2153-05$
\end{tabular} & & 2153-09 & & & 1 \\
\hline \multirow[t]{3}{*}{ Chloride } & Observation & & & & & $\begin{array}{l}2054-03 \\
2153-09\end{array}$ & 3 \\
\hline & $\begin{array}{l}\text { Deep } \\
\text { monitoring }\end{array}$ & & & & & $2153-05$ & 1 \\
\hline & Pumped & $2153-02$ & & & & & 0 \\
\hline \multicolumn{8}{|c|}{ Honolulu } \\
\hline Water level & Observation & \begin{tabular}{|l}
$1851-19 \mathrm{AB}$ \\
$1851-22$
\end{tabular} & . & \begin{tabular}{|l|}
$1748-01$ \\
$1748-12$ \\
$1749-22$ \\
$1851-02$ \\
$2052-10$
\end{tabular} & & & 2 \\
\hline \multirow[t]{3}{*}{ Chloride } & Observation & 1851-09B & & & & $\begin{array}{l}1748-01 \\
1748-12 \\
1749-22 \\
1851-02 \\
2052-10\end{array}$ & 7 \\
\hline & $\begin{array}{l}\text { Deep } \\
\text { monitoring }\end{array}$ & & & \begin{tabular}{|l}
$1748-14$ \\
$1851-57$
\end{tabular} & & & 0 \\
\hline & Pumped & & & & & & 0 \\
\hline
\end{tabular}

Figure 10. Water-management network wells and number of additional locations needed, Oahu, Hawaii, 1992. 


\begin{tabular}{|c|c|c|c|c|c|c|}
\hline \multirow[b]{2}{*}{$\begin{array}{c}\text { Type of } \\
\text { data collected }\end{array}$} & \multirow[b]{2}{*}{ Well type } & \multicolumn{3}{|c|}{$\begin{array}{c}1992 \text { GROUND-WATER DATA } \\
\text { COLLECTION PROGRAMS }\end{array}$} & \multicolumn{2}{|c|}{$\begin{array}{c}\text { ADDITIONAL } \\
\text { LOCATIONS NEEDED }\end{array}$} \\
\hline & & USGS & BWS & CWRM & Candidate & $\begin{array}{l}\text { Total no. } \\
\text { needed }\end{array}$ \\
\hline \multicolumn{7}{|c|}{ Ewa } \\
\hline Water level & Observation & $\begin{array}{l}2006-12 \\
2103-01 \\
2103-03^{b}\end{array}$ & $\begin{array}{l}2006-12 \\
2103-01 \\
2103-02\end{array}$ & & & 4 \\
\hline \multirow[t]{3}{*}{ Chloride } & Observation & & & & $\begin{array}{l}2006-12 \\
2103-01,02\end{array}$ & 6 \\
\hline & $\begin{array}{l}\text { Deep } \\
\text { monitoring }\end{array}$ & & & 2303-07 & & 0 \\
\hline & Pumped & $\begin{array}{l}2103-01 \\
2603-01\end{array}$ & & & & 0 \\
\hline \multicolumn{7}{|c|}{ Waialua } \\
\hline Water level & Observation & & $3406-04$ & & $\begin{array}{l}3304-01 \\
3306-13,14 \\
3406-12 \\
3406-13 \\
3406-14,15 \\
3407-36 \\
3503-01 \\
3505-25 \\
3505-26 \\
3604-01 \\
\end{array}$ & 10 \\
\hline \multirow[t]{3}{*}{ Chloride } & Observation & & & & $\begin{array}{l}3304-01 \\
3306-13,14 \\
3406-13 \\
3406-14,15 \\
3407-36 \\
3503-01 \\
3505-25 \\
3505-26\end{array}$ & 8 \\
\hline & $\begin{array}{l}\text { Deep } \\
\text { monitoring }\end{array}$ & & & & $\begin{array}{l}3406-12 \\
3604-01 \\
\end{array}$ & 2 \\
\hline & Pumped & $\begin{array}{l}3405-01 \\
3405-02 \\
3407-25 \\
3407-30 \\
3506-03,04\end{array}$ & & & & 0 \\
\hline \multicolumn{7}{|c|}{ Kahuku } \\
\hline Water level & Observation & 4057-05 & & & $3452-01$ & 8 \\
\hline \multirow[t]{3}{*}{ Chloride } & Observation & $\begin{array}{l}3251-01^{\mathrm{a}} \\
3956-04^{\mathrm{a}} \\
4258-04^{\mathrm{a}}\end{array}$ & & & $3452-01$ & 8 \\
\hline & $\begin{array}{l}\text { Deep } \\
\text { monitoring }\end{array}$ & & 3553-05 & & & 0 \\
\hline & Pumped & $\begin{array}{l}3655-01 \\
4100-01 \\
\end{array}$ & & & & 0 \\
\hline \multicolumn{7}{|c|}{ Koolau rift zone } \\
\hline Water level & Observation & & & & 2448-01 & 0 \\
\hline
\end{tabular}

${ }^{\text {a }}$ Free-flowing well

b Pumped well

USGS, U.S. Geological Survey

BWS, Honolulu Board of Water Supply

CWRM, Commission on Water Resource Management

Figure 10. Water-management network wells and number of additional locations needed, Oahu, Hawaii, 1992--Continued. 


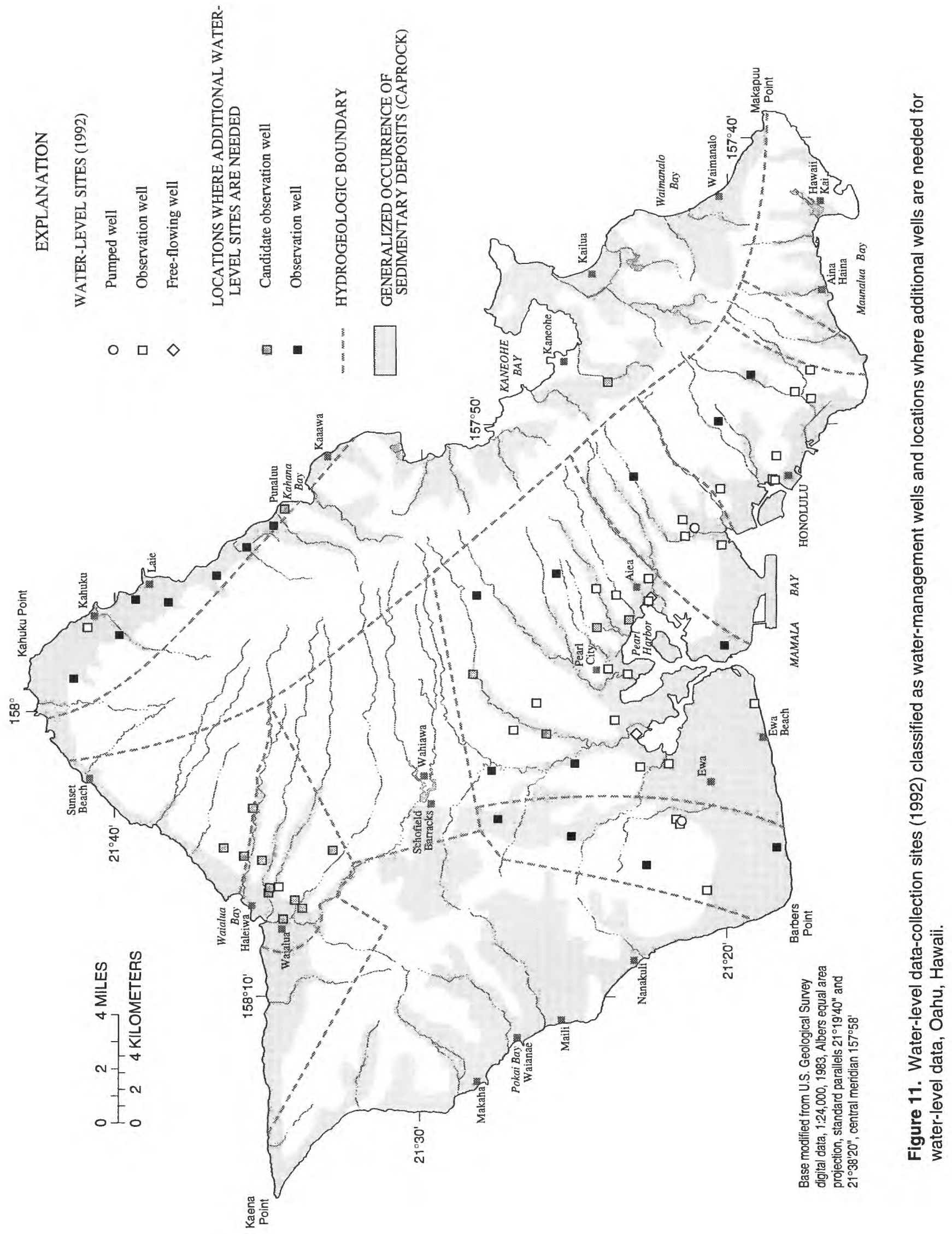


nani Gulch between Pearl City and Aiea (fig. 7). The CWRM collected water-quality samples from the deep monitoring wells near Waipahu (2300-18) and Waipio (2659-01) (fig. 7). All of these wells were classified as water-management wells for the collection of chlorideconcentration data (fig. 10). A deep monitoring well (1959-05) (fig. 6) near Ewa Beach needs to be field checked to determine if it is suitable for monitoring the movement of the zone of transition between freshwater and saltwater beneath the caprock on the Ewa plain. Locations where additional observation wells open to the producing zone are needed for chloride-concentration data are shown in figure 12 . The observation well locations are the same as those needed for water-level data.

Moanalua.--The Moanalua ground-water area is bounded by the valley-fill deposits of Kalihi Stream to the east, the Koolau rift zone to the northeast, and valley-fill deposits of Halawa Stream to the west (figs. 3 and 4). In the Moanalua area, a thick basal-water body occurs in the lavas of the Koolau Basalt owing to the occurrence of caprock at the coast (fig. 4). Wells in the basal-water body contained in the Koolau Basalt have water levels of about $25 \mathrm{ft}$ above mean sea level. Three pumped wells in the area had a combined pumpage of about $10.4 \mathrm{Mgal} / \mathrm{d}$ in 1990 (fig. 8). In addition, three pumped wells are proposed in the area.

Water levels were measured by the USGS in two observation wells and one pumped well in the Moanalua area in 1992; continuous water levels were recorded in one of the observation wells (fig. 5 and table 2). In addition, the BWS collected water-level data from one observation well in the area (fig. 7). All of these wells were classified as water-management wells for the collection of water-level data (fig. 10). Locations where additional observation wells are needed for water-level data are shown in figure 11. An additional observation well is needed near observation-well 205403 (fig. 5) to determine the occurrence and movement of ground water in the caprock and the underlying Koolau Basalt. The additional observation well is needed in the caprock because the existing well (205403) is finished in the underlying Koolau Basalt.

Water-quality samples were collected by the USGS from one pumped well in the Moanalua area in 1992 (fig. 6 and table 2). This well was classified as a water-management well for the collection of chlorideconcentration data (fig. 10). The Moanalua deep moni- toring well (2153-05) owned by the CWRM could be added to the network. However, the PVC casing in the well needs to be removed to allow free movement of a down-hole sampler. Locations where additional observation wells open to the producing zone are needed for chloride-concentration data are shown in figure 12 . The observation well locations are the same as those needed for water-level data. Candidate wells for inclusion in the water-management network are listed in figure 10 .

Honolulu.--The Honolulu ground-water area is bounded by the Kaau rift zone to the east, the Koolau rift zone to the northeast, and valley-fill deposits of Kalihi Stream to the west (figs. 3 and 4). In the Honolulu area, a thick basal-water body occurs in the lavas of the Koolau Basalt owing to the occurrence of caprock at the coast (fig. 3). Wells in the basal-water body contained in the Koolau Basalt have water levels that range from 26 to $29 \mathrm{ft}$ above mean sea level. Fourteen pumped wells in the area had a combined pumpage of about 36.9 $\mathrm{Mgal} / \mathrm{d}$ in 1990 (fig. 8). In addition, nine pumped wells are proposed in Honolulu area (fig. 9).

Water levels were measured by the USGS in two observation wells in the Honolulu area in 1992 (fig. 5 and table 2). In addition, the BWS collected water-level data from five observation wells in the area (fig. 7). All of these wells were classified as water-management wells for the collection of water-level data (fig. 10). Locations where additional observation wells are needed for water-level data are shown in figure 11. An additional observation well (not shown in fig. 11) is needed at one of the existing observation-well locations to monitor the occurrence and movement of ground water in both the caprock and in the underlying Koolau Basalt. The additional observation well will be needed in the caprock because the existing observation well is finished in the underlying Koolau Basalt.

Water-quality samples were collected by the USGS from one observation well in the Honolulu area in 1992 (fig. 6 and table 2). In addition, the BWS collected specific-conductance data from the Kaimuki (1748-14) and Beretania (1851-57) deep monitoring wells (fig. 7). All of these wells were classified as water-management wells for the collection of chlorideconcentration data (fig. 10). Locations where additional observation wells open to the producing zone are needed for chloride-concentration data are shown in figure 12. The observation well locations are the same as those needed for water-level data. Candidate wells for 


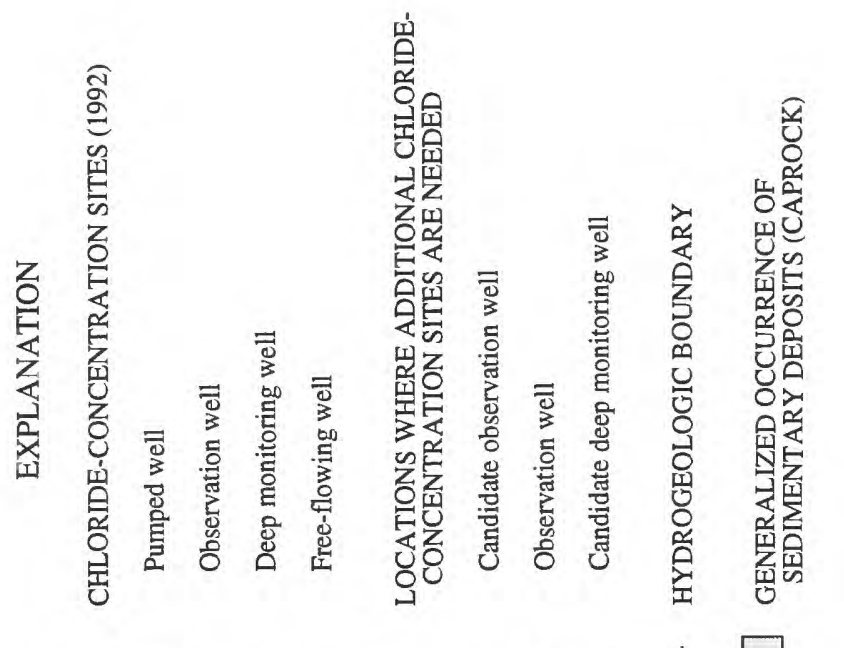

D

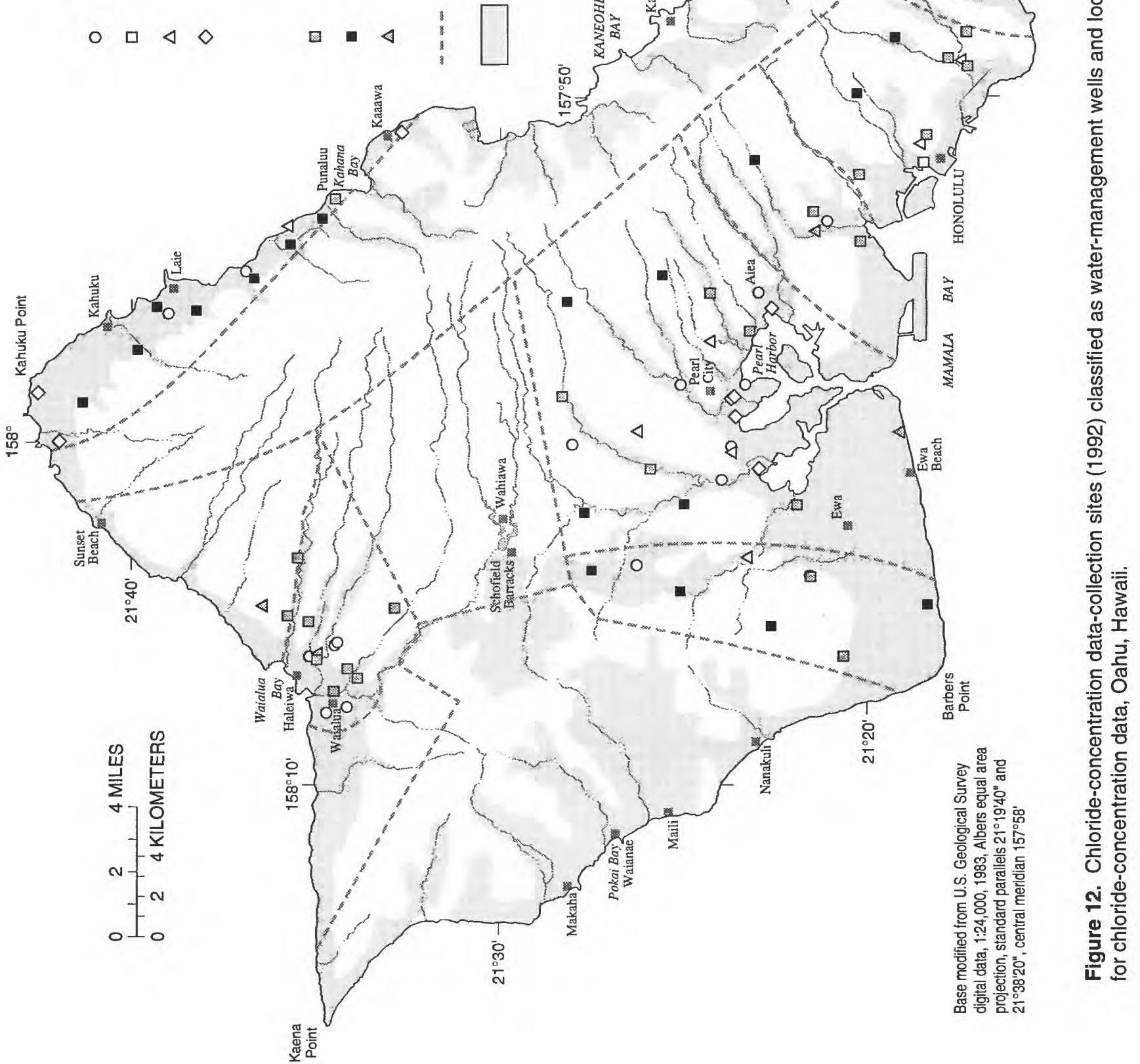


inclusion in the water-management network are listed in figure 10.

Ewa.--The Ewa ground-water area is bounded by the Koolau-Waianae unconformity to the east, dikes or other structures of the Schofield high-level water body to the north, and the Waianae rift zone to the west (figs. 3 and 4). In the Ewa area, a thick basal-water body occurs in the lavas of the Koolau Basalt owing to the occurrence of caprock at the coast (fig. 4). Wells in the basal-water body contained in the Koolau Basalt have water levels that range from 14 to $26 \mathrm{ft}$ above mean sea level (fig. 3). Wells in the caprock have water levels that are less than $3 \mathrm{ft}$ above mean sea level. Nine pumped wells in the area had a combined pumpage of about 11 Mgal/d in 1990 (fig. 8). In addition, 30 pumped wells are proposed in the Ewa area, most of which are for withdrawing brackish water from the caprock.

Water levels were measured by the USGS in two observation wells and one pumped well in the Ewa area in 1992 (fig. 5 and table 2). In addition, the BWS collected water-level data from three observation wells in the Ewa area in 1992 (fig. 7). All of these wells were classified as water-management wells for the collection of water-level data (fig. 10). Locations where additional observation wells are needed for water-level data are shown in figure 11. An additional observation well (not shown in fig. 11) is needed at one of the existing observation-well locations to monitor the occurrence and movement of ground water in both the caprock and the underlying Koolau Basalt. The additional observation well is needed in the caprock because the existing observation well is finished in the underlying Koolau Basalt.

Water-quality samples were collected by the USGS from two pumped wells in the Ewa ground-water area in 1992 (fig. 6 and table 2). In addition, the CWRM collected water-quality samples from the Honouliuli (2303-07) deep monitoring well (fig. 7). All of these wells were classified as water-management wells (fig. 10) for the collection of chloride-concentration data. Locations where additional observation wells open to the producing zone are needed for chloride-concentration data are shown in figure 12 . The observation well locations are the same as those needed for water-level data. Candidate wells for inclusion in the water-management network are listed in figure 10 .

Waialua.--The Waialua ground-water area is bounded by valley-fill deposits of Anahulu River to the east, dikes or other structures of the Schofield highlevel water body to the south, and the Koolau-Waianae unconformity to the west (figs. 3 and 4). In the Waialua area, a moderately thick basal-water body occurs in the lavas of the Koolau Basalt owing to the occurrence of caprock at the coast (fig. 4). Wells in the basal-water body contained in the Koolau Basalt have water levels that range from about 10 to $13 \mathrm{ft}$ above mean sea level. Twelve pumped wells in the area had a combined pumpage of about $23.7 \mathrm{Mgal} / \mathrm{d}$ in 1990 (fig. 8). No pumped wells are proposed in the area (fig. 9), although the BWS is interested in developing additional sources of water. As part of a cooperative USGS/BWS groundwater availability study, observation wells were drilled at 10 locations in the Waialua-Kawailoa area in 199394. Deep monitoring wells that penetrate the zone of transition between freshwater and saltwater were drilled at two of these locations.

No water-level data were collected in the Waialua area in 1992 as part of the USGS ground-water data-collection program. However, the BWS collected waterlevel data from one observation well (fig. 7) that was classified as a water-management network well for the collection of water-level data (fig. 10). The wells in the Waialua-Kawailoa area that were drilled as part of the USGS/BWS ground-water availability study were classified as candidate wells for the water-management network for the collection of water-level data (figs. 10 and 11). No additional observation wells are needed for water-level data in the Waialua area.

Water-quality samples were collected by the USGS from five pumped wells in the Waialua area in 1992 (fig. 6 and table 2). These wells were classified as water-management network wells for the collection of chloride-concentration data. The wells in the WaialuaKawailoa area that were drilled as part of the USGS/BWS ground-water availability study were classified as candidate water-management wells for chloride-concentration data (figs. 10 and 12). No additional observation wells are needed for chloride-concentration data in the Waialua area.

Kahuku.--The Kahuku ground-water area is located at the northeastern end of the Koolau mountain range and is bounded by the Koolau rift zone to the west (figs. 3 and 4). In the Kahuku area, a moderately thick basal-water body occurs in the lavas of the Koolau Basalt owing to the occurrence of caprock at the coast (fig. 4). Wells in the basal-water body contained in the 
Koolau Basalt have water levels that range from about 8 to $22 \mathrm{ft}$ above mean sea level. Wells in the caprock have water levels that are less than $3 \mathrm{ft}$ above mean sea level. Thirteen pumped wells in the area had a combined pumpage of about $11 \mathrm{Mgal} / \mathrm{d}$ in 1990 (fig. 8). In addition, fourteen pumped wells are proposed in the area (fig. 9).

Water levels were measured by the USGS in one observation well (4057-05) in the Kahuku area in 1992 (fig. 5 and table 2). This well was classified as a watermanagement well for the collection of water-level data (fig. 10). Locations where additional observation wells are needed for water-level data are shown in figure 11. Two observation wells are needed at several of these locations to determine the occurrence and movement of ground water in the caprock and the underlying Koolau Basalt; one well in the caprock and one in the underlying Koolau Basalt. A candidate well for inclusion in the water-management network is listed in figure 10 .

Water-quality samples were collected by the USGS from two pumped wells and three free-flowing wells in the Kahuku area in 1992 (fig. 6 and table 2). In addition, the BWS collected specific-conductance data from a deep monitoring well (3553-05) near Punaluu

(fig. 7). All of these wells were classified as water-management wells for the collection of chloride-concentration data (fig. 10). Locations where additional observation wells open to the producing zone are needed for chloride-concentration data are shown in figure 12. The observation well locations are the same as those needed for water-level data.

Koolau rift zone.--A water-management network to observe the effect of pumping dike-impounded water on ground-water levels and ground-water discharge to streams is needed in the area between Waikane and Kahanaiki Streams (fig. 5) in the Koolau rift zone. The nearly vertical dikes in the Koolau rift zone retard the flow of ground water resulting in water levels between 700 and $900 \mathrm{ft}$ above mean sea level. Sixteen sources in the area, which include pumped wells and water-development tunnels, had a combined withdrawal of about 12 Mgal/d in 1990 (fig. 8). In addition, 10 pumped wells are proposed in the area (fig. 9). Water-level data were not collected in the Waikane to Kahanaiki Stream part of the Koolau rift zone in 1992 as part of the USGS ground-water data-collection program.

Additional information on the hydrologic interaction between ground water and surface water is needed to determine locations where observation wells are needed for water-level data. A series of streamflow measurements (seepage runs) made along each stream during baseflow conditions would provide information on where streams gain and lose water. This information could be used to estimate the spatial and vertical distribution of observation wells needed to monitor hydraulic gradients and the effect of pumping dike-impounded water on ground-water levels and ground-water discharge to streams in the Koolau rift zone.

\section{Kauai}

Kauai is a single shield volcano that has been deeply eroded by streams and capped in many areas by late-stage (rejuvenated) volcanic material (Macdonald and others, 1960) (fig. 13). The Waimea Canyon Basalt, which forms most of the island, includes thick accumulations of thin lava flows (Napali Member) and massive caldera-filling and graben-filling lavas (Olokele and Makeweli Members, respectively). The porous lavas of the Napali Member are the most permeable rocks on Kauai, but are exposed on less than 50 percent of the island's surface because they are overlain by the younger rejuvenated-stage Koloa Volcanics (Macdonald and others, 1960). The Koloa Volcanics was erupted from vents scattered over the eroded shield volcano, and is found as high as $4,700 \mathrm{ft}$ above sea level. The Koloa Volcanics is most extensive at lower elevations where it fills valleys, gorges, and depressions in the Waimea Canyon Basalt. The Koloa Volcanics is a heterogeneous unit made up of lava flows, ash, tuff, and cinder. Erosional unconformities and associated sediments are common in the unit. The Koloa Volcanics thus has low to moderate permeability (Macdonald and others, 1960).

In 1992, the USGS ground-water data-collection program consisted of 9 observation wells, and 33 pumped wells (table 3 ). Water levels were measured at about 8-week intervals in 5 of the observation wells, and 19 of the pumped wells (fig. 14). In addition, continuous water levels were recorded in observation wells near Hanamaulu Stream (5921-01) and Hanapepe River (5634-01) (fig. 14). The recorder on observation well 5921-01 was moved in July 1992 to observation well 0120-01 located between Hanamaulu Stream and Wailua River (fig. 14). Water-quality samples were collected at about 8-week intervals from 30 of the pumped wells (fig. 15). Because the wells were not being 


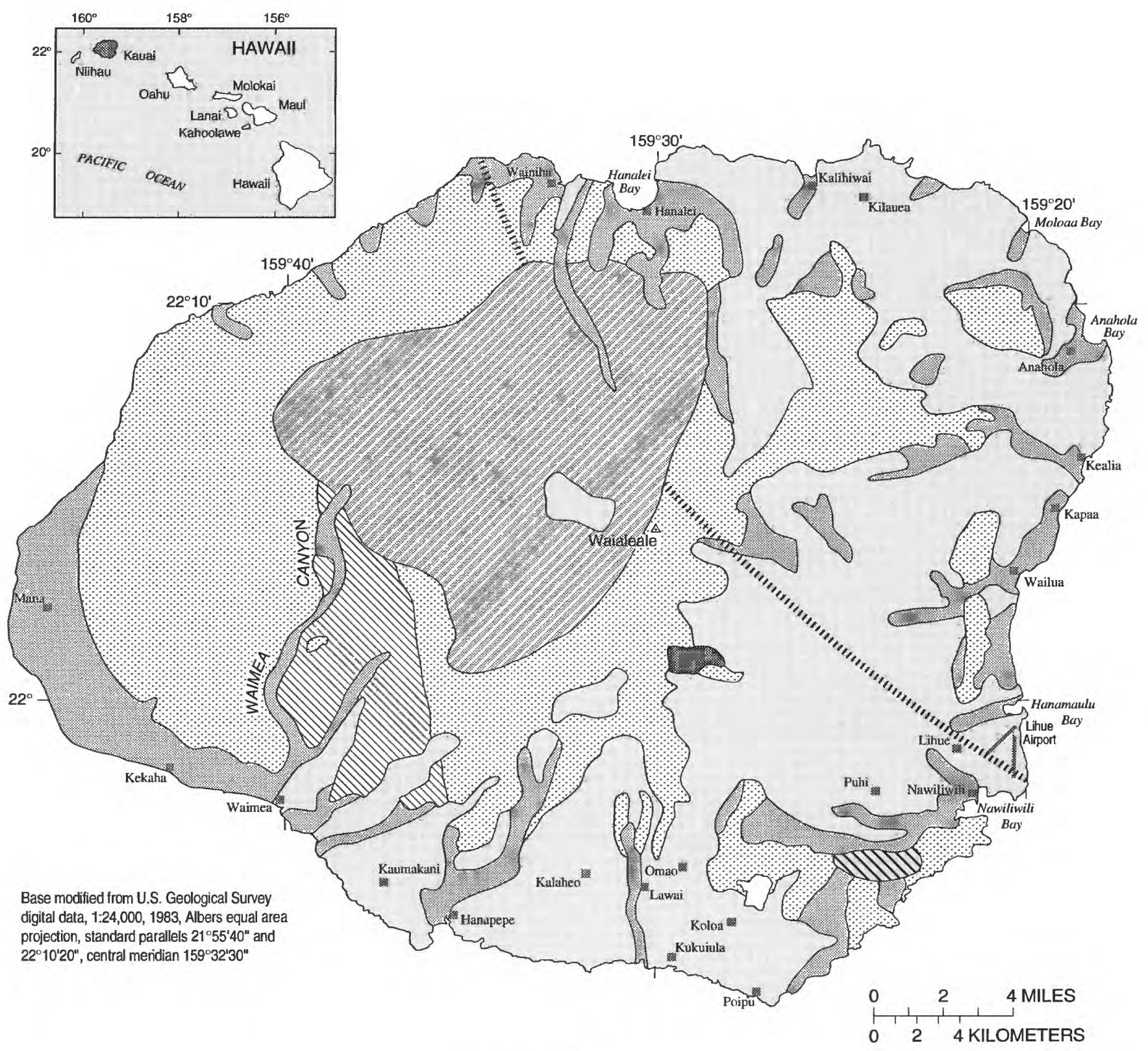

EXPLANATION

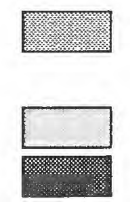

SEDIMENTARY DEPOSITS (Holocene)

KOLOA VOLCANICS (Pleistocene and Pliocene)

Palikea Breccia Member (Pleistocene? and Pliocene?)

CONTACT

‘!ı!!! RIFT ZONE--Approximately located
WAIMEA CANYON BASALT (Pliocene and Miocene?)

Makaweli Member (Pliocene)--Flank graben. Includes Mokuone Breccia Beds

Olokele Member (Pliocene)--Summit caldera

Haupu Member (Pliocene)--Flank caldera

Napali Member (Pliocene and Miocene?)-Lava flows

WAITA RESERVOIR

Figure 13. Generalized geology of Kauai, Hawaii (modified from Langenheim and Clague, 1987). 


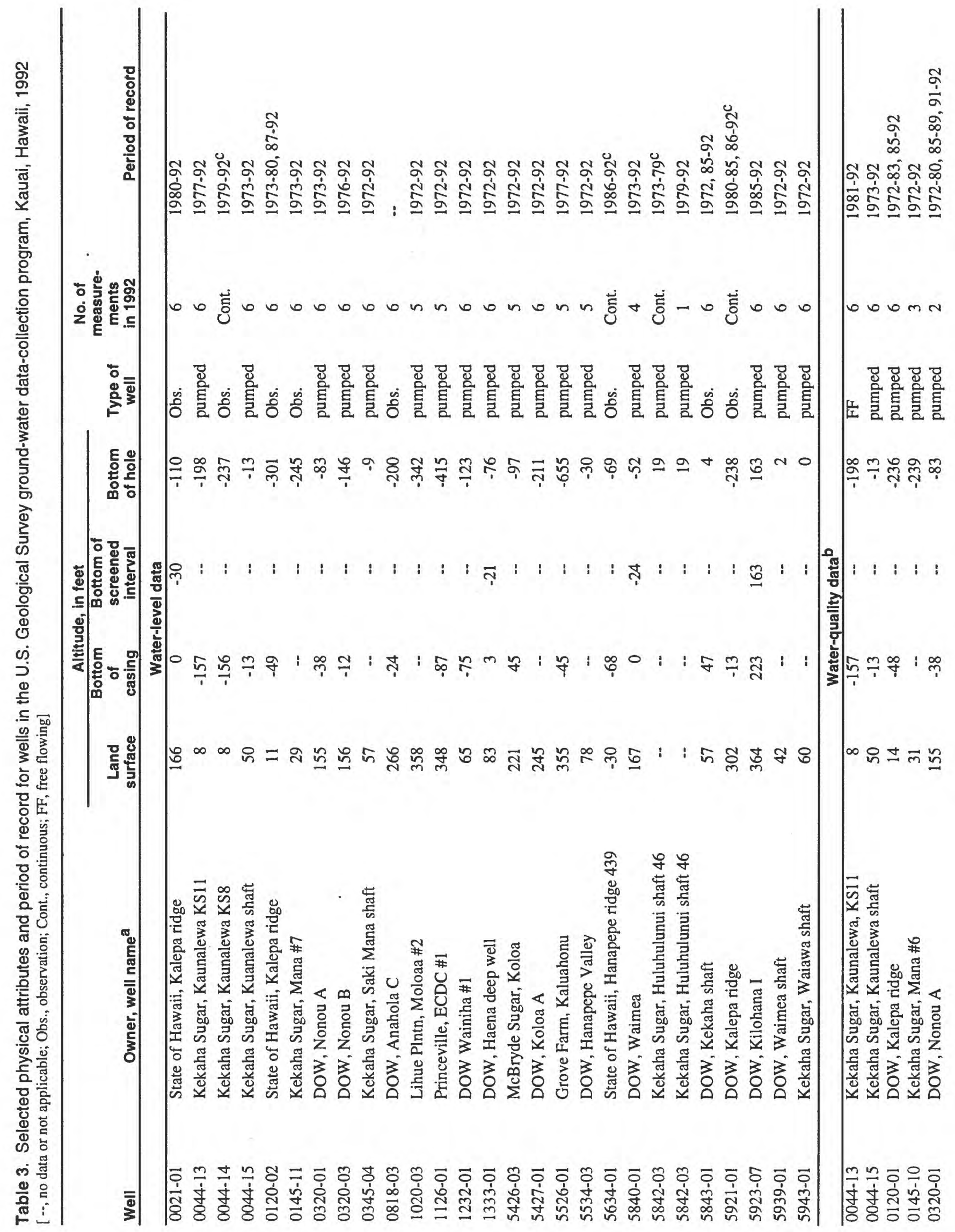




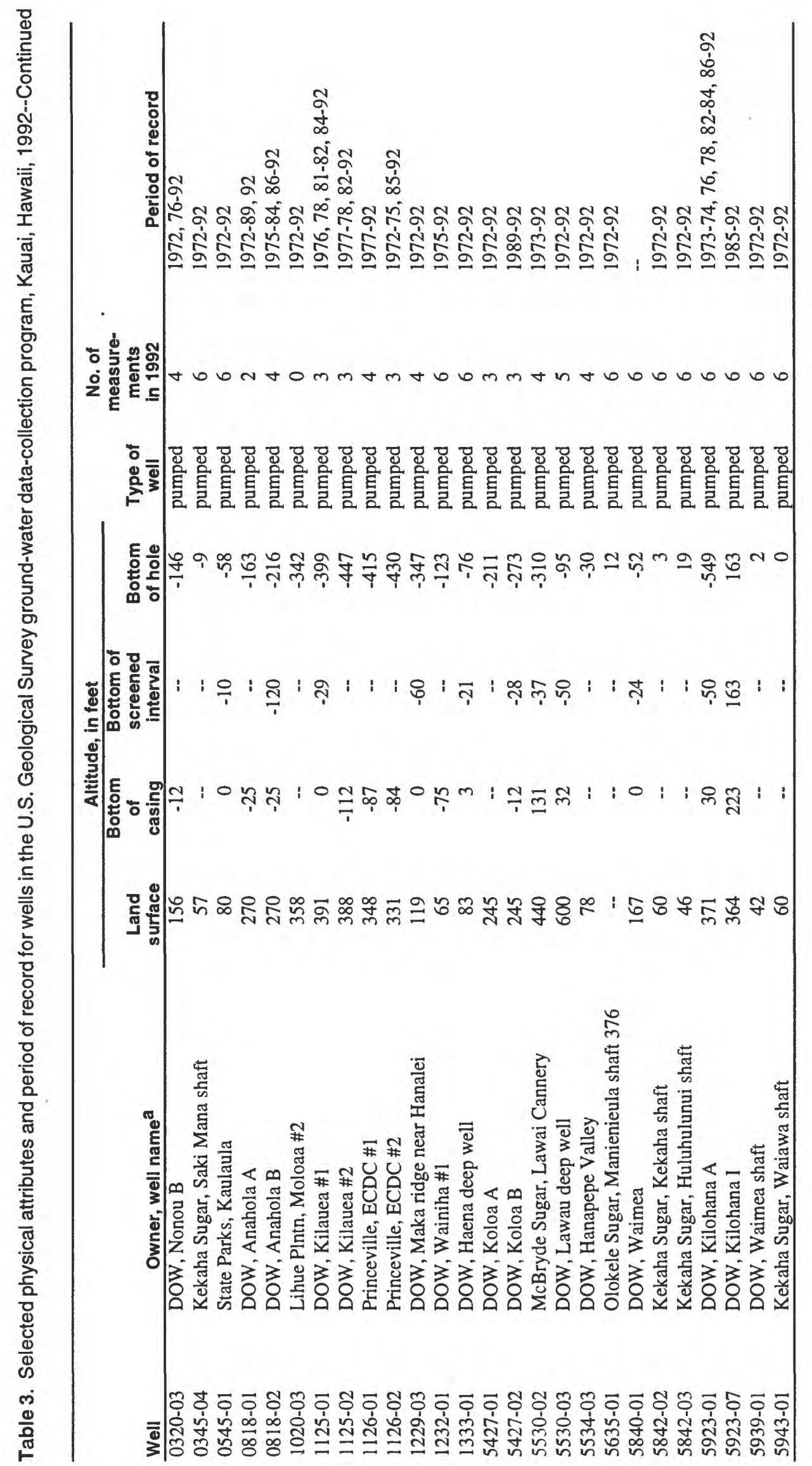




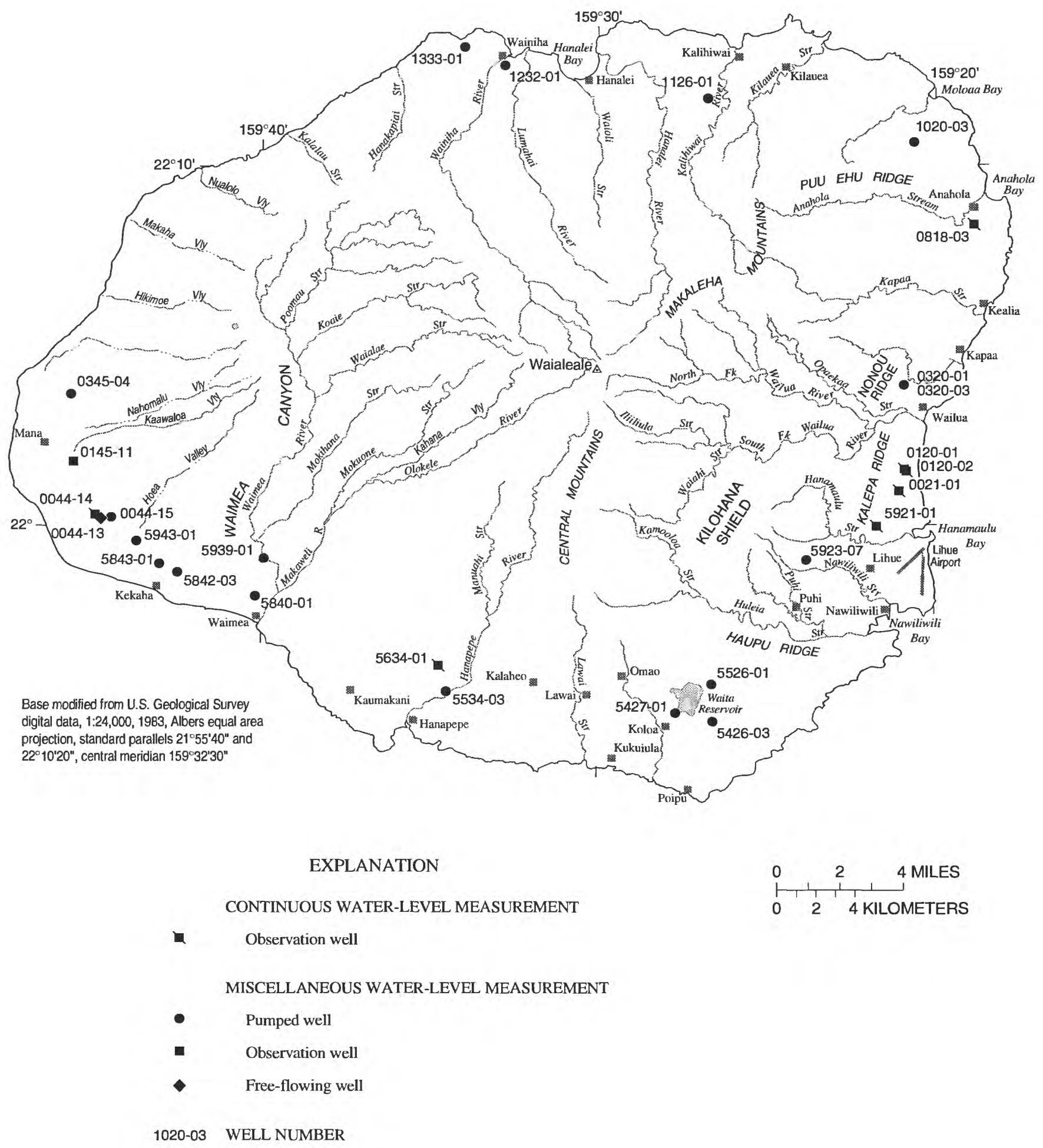

Figure 14. Wells where water-level data were collected as part of the U.S. Geological Survey ground-water data-collection program, Kauai, Hawaii, 1992. 


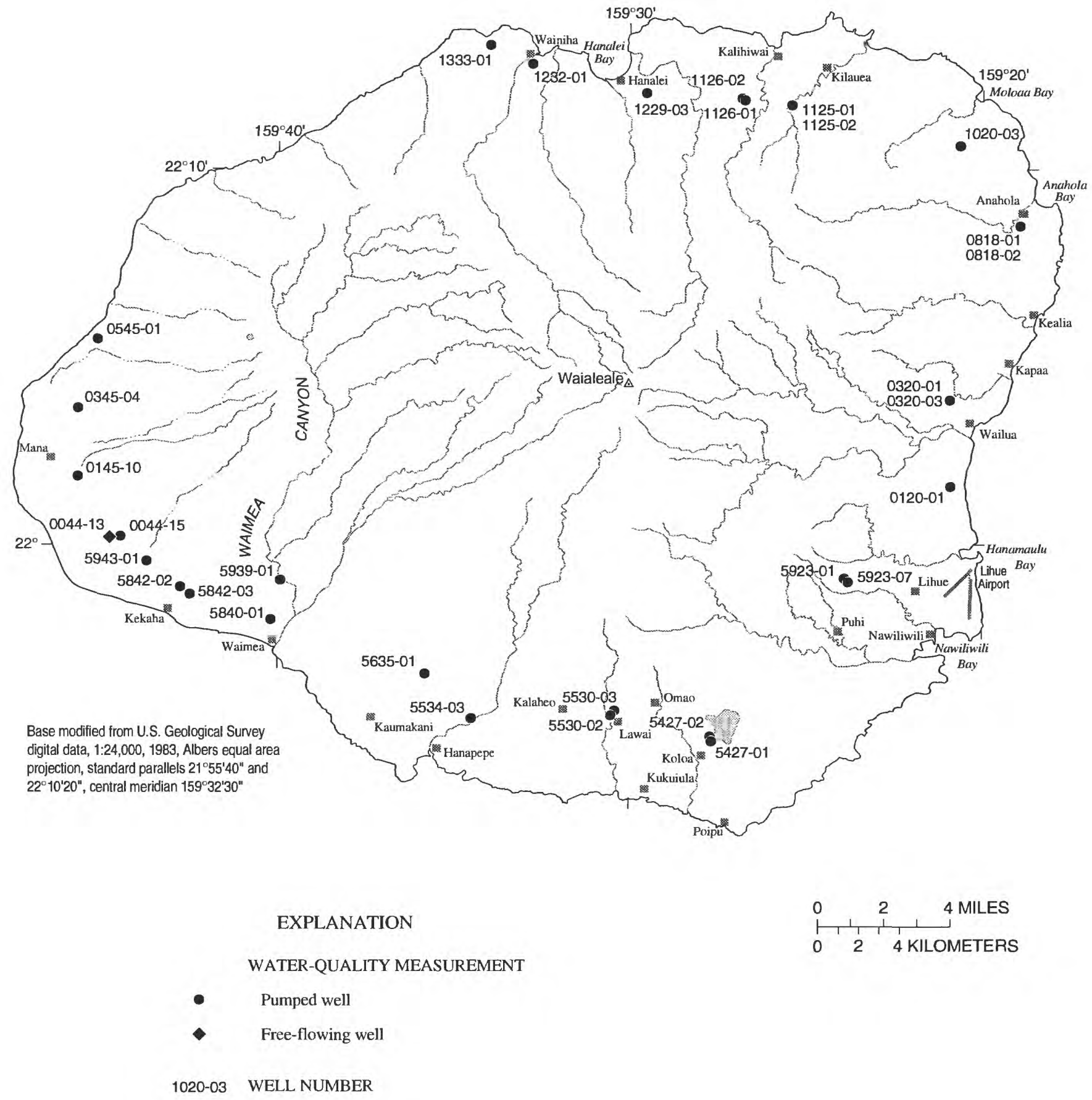

Figure 15. Wells where water-quality data were collected as part of the U.S. Geological Survey ground-water data-collection program, Kauai, Hawaii, 1992. 
pumped during each site visit, the record of water-quality data is incomplete for nine of the 29 pumped wells sampled. Well depth is known for all of the wells.

Ground-water pumpage on the island of Kauai averaged about $22 \mathrm{Mgal} / \mathrm{d}$ in 1992 on the basis of data reported to the CWRM. About $12 \mathrm{Mgal} / \mathrm{d}$, was used for municipal or domestic purposes. The remainder, about $10 \mathrm{Mgal} / \mathrm{d}$, was used for agriculture (mostly sugarcane), landscaping, and golf courses. The demand for potable ground water is projected to increase by about 12.5 Mgal/d by the year 2011 (State of Hawaii, Commission on Water Resource Management, 1992b). The demand for ground water suitable for agriculture, landscaping, and golf courses is projected not to increase by the year 2011 (State of Hawaii, Commission on Water Resource Management, 1992b). Although the amount of acreage in diversified agriculture, landscaping, and golf courses is projected to increase, the overall irrigated acreage on Kauai is not expected to increase owing to a gradual decline in sugarcane acreage. The distribution and magnitude of 1992 pumpage (fig. 16) and the distribution of proposed pumped wells (fig. 17) indicate a need for water-management networks in the Lihue, Kapaa, and Koloa areas of the island. Wells needed to meet the objectives of a water-management network in these areas are described below.

Lihue.--The Lihue area is bounded by Huleia Stream to the south, Wailua River to the north, and the high central mountains of the island to the west (fig. 13). The surrounding mountains and ridges are composed of lava flows of the Waimea Canyon Basalt, primarily the Napali Member. The central part of the area is covered by late-stage lavas of the Koloa Volcanics. These lavas form the Kilohana shield, which has a diameter of nearly $6 \mathrm{mi}$ and rises to an altitude of 1,134 ft. The southeastern slope of the shield extends as a lava plain between the Kalepa and Haupu ridges. Basal water occurs in the lava flows of the Napali Member in Kalepa ridge, and in most of Haupu ridge (Macdonald and others, 1960). Wells in Kalepa ridge have basal heads ranging from 5 to $16 \mathrm{ft}$, which probably are produced by the impounding effects of the low-permeability Koloa Volcanics surrounding the ridge (Macdonald and others, 1960). A thick basal-water body occurs in the Kilohana shield of the Koloa Volcanics. Water levels in this thick basal-water body range from 5 to $590 \mathrm{ft}$ above mean sea level (Gingerich and Izuka, 1997).
In 1992, the Kauai County Department of Water (DOW) pumped an average of $3.8 \mathrm{Mgal} / \mathrm{d}$ in the Lihue district. The Kauai Lagoons pumped an average of 0.3 $\mathrm{Mgal} / \mathrm{d}$ for landscaping and golf courses near the Lihue airport. The demand for water is projected to increase by $3.8 \mathrm{Mgal} / \mathrm{d}$ by the year 2011 (State of Hawaii, Commission on Water Resource Management, 1992b). Most ground water withdrawn from the district is derived from a thick basal-water body in the Kilohana shield. In addition to the proposed pumped wells in the Lihue area (fig. 17), the DOW is planning to explore for basal water along the margins of the Lihue basin where the more permeable Napali Member is located at or near land surface.

Water-level measurements were made by the USGS in three observation wells and one pumped well in the Lihue area in 1992 (fig. 13 and table 3). All of these wells were classified as water-management wells for the collection of water-level data (fig. 18). No observation wells exist in the program for collecting waterlevel data from the thick basal-water body in the Koloa Volcanics of the Kilohana shield. Locations where additional observation wells are needed for water-level data are shown in figure 19. Candidate wells for inclusion in the water-management network are listed in figure 18. To obtain an accurate estimate of the water-table configuration, observation wells need to be drilled to a depth slightly below the first occurrence of water. In addition, the wells need to be sufficiently deep so that seasonal and long-term fluctuations in water levels can be measured, but not so deep that the measured water level is affected by vertical flow gradients.

Water-quality samples were collected by the USGS from three pumped wells in the Lihue area (fig. 15 and table 3). Because water-management networks are designed to monitor the distribution of freshwater and the zone of transition between freshwater and saltwater in basal-water bodies, only two of the three pumped wells in the program, wells 5923-01 and 012001 , were classified as water-management wells for the collection of chloride-concentration data (figs. 18 and 20). Pumped well 5923-07 was not classified as a watermanagement network well because it yields high-level water with a stable chloride concentration of about 20 $\mathrm{mg} / \mathrm{L}$. To monitor the chloride concentration in basal water withdrawn from the area between Puhi and Nawiliwili Streams, the DOW pumped wells 5824-01 and 5822-02 were identified as candidate water-management wells for the collection of chloride-concentration 


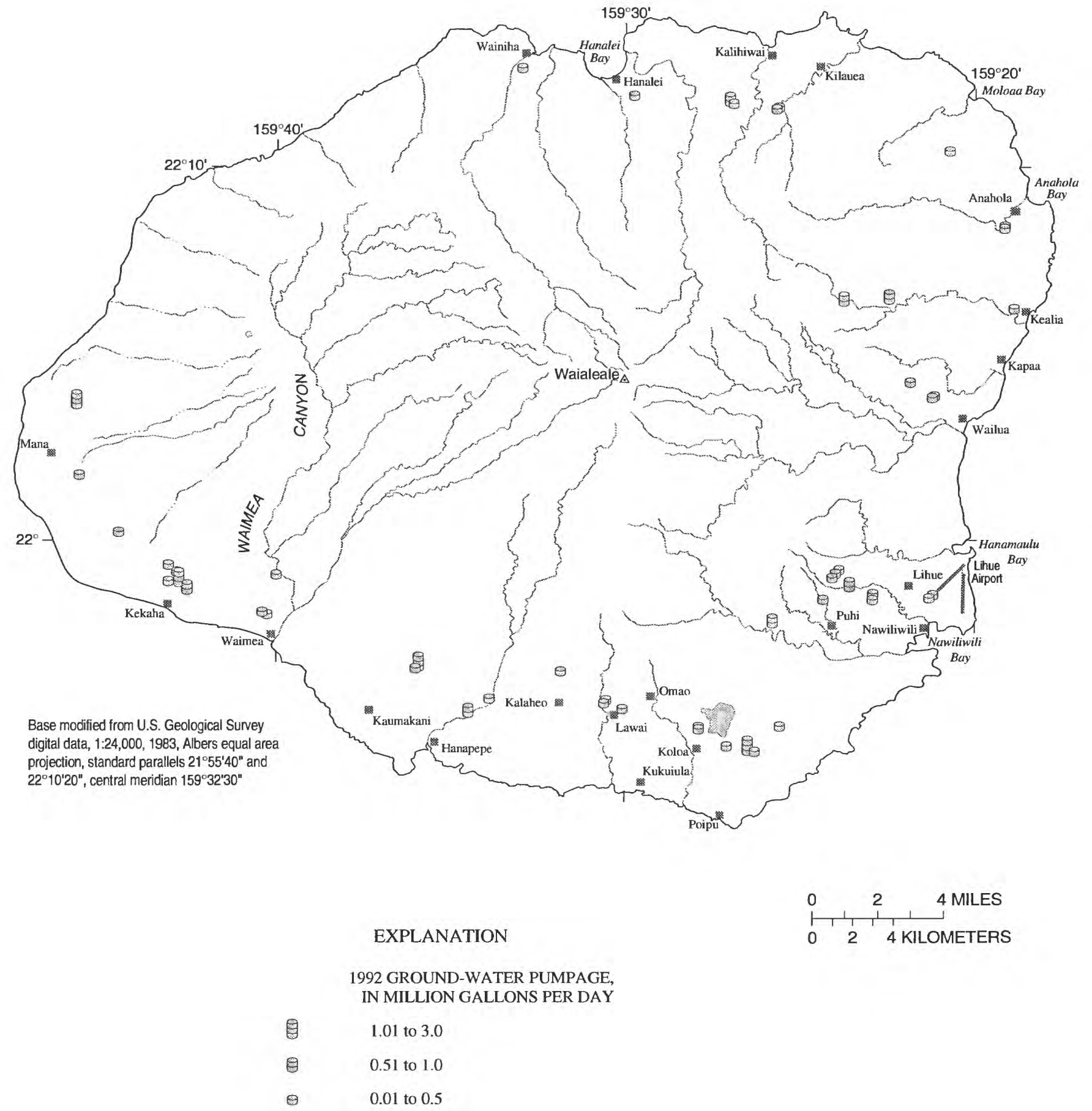

Figure 16. Distribution and magnitude of ground-water pumpage, Kauai, Hawaii, 1992. 


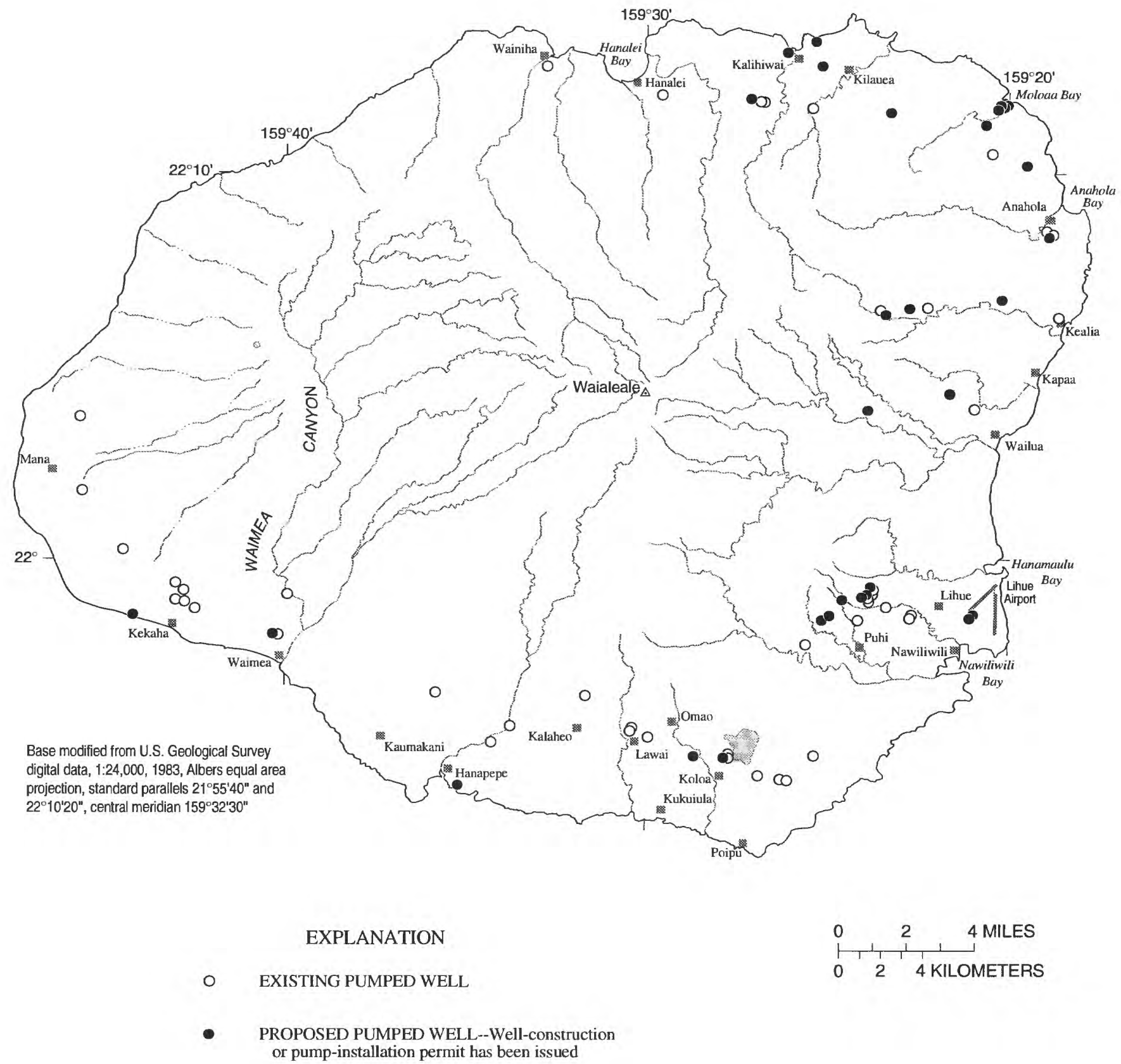

Figure 17. Existing and proposed (permit has been issued) pumped wells, Kauai, Hawaii, 1992. 


\begin{tabular}{|c|c|c|c|c|}
\hline \multirow[b]{2}{*}{$\begin{array}{l}\text { Type of data } \\
\text { collected }\end{array}$} & \multirow[b]{2}{*}{ Well type } & \multirow[b]{2}{*}{$\begin{array}{c}1992 \\
\text { PROGRAM }\end{array}$} & \multicolumn{2}{|c|}{$\begin{array}{c}\text { ADDITIONAL } \\
\text { LOCATIONS NEEDED }\end{array}$} \\
\hline & & & Candidate & $\begin{array}{c}\text { Total } \\
\text { number needed }\end{array}$ \\
\hline \multicolumn{5}{|c|}{ Lihue } \\
\hline Water level & Observation & $\begin{array}{l}0120-02 \\
0021-01 \\
5921-01 \\
5923-07^{a}\end{array}$ & $\begin{array}{l}0020-01 \\
5821-02 \\
5821-05 \\
5823-03 \\
5824-02 / 04 \\
0221-02 \\
5923-06\end{array}$ & 14 \\
\hline \multirow[t]{3}{*}{ Chloride } & Observation & & $\begin{array}{l}0020-01 \\
5821-02 \\
5821-05 \\
0120-02 \\
0021-01 \\
5921-01 \\
0221-02\end{array}$ & 12 \\
\hline & Deep monitoring & & & 2 \\
\hline & Pumped & $\begin{array}{l}0120-01 \\
5923-01\end{array}$ & $\begin{array}{l}5824-01 \\
5822-02\end{array}$ & 2 \\
\hline \multicolumn{5}{|c|}{ Kapaa } \\
\hline Water level & Observation & $\begin{array}{l}0320-01^{a} \\
0320-03^{a} \\
0818-03\end{array}$ & $\begin{array}{l}0320-02 \\
0419-01 \\
0419-02 \\
0421-01 \\
0618-01 / 07\end{array}$ & 9 \\
\hline \multirow[t]{3}{*}{ Chloride } & Observation & & $\begin{array}{l}0320-02 \\
0419-01 \\
0419-02 \\
0421-01 \\
0618-01 / 07\end{array}$ & 7 \\
\hline & Deep observation & & & 2 \\
\hline & Pumped & $\begin{array}{l}0320-01 \\
0320-03 \\
0818-01 \\
0818-02\end{array}$ & & 0 \\
\hline \multicolumn{5}{|c|}{ Koloa } \\
\hline Water level & Observation & $\begin{array}{l}5426-03^{\mathrm{a}} \\
5427-01^{\mathrm{a}} \\
5526-01^{\mathrm{a}}\end{array}$ & $\begin{array}{l}5529-01 \\
5531-01 \\
5727-01\end{array}$ & 9 \\
\hline \multirow[t]{3}{*}{ Chloride } & Observation & & $\begin{array}{l}5529-01 \\
5531-01 \\
5727-01\end{array}$ & 6 \\
\hline & Deep monitoring & & & 3 \\
\hline & Pumped & $\begin{array}{l}5427-01 \\
5427-02 \\
5530-02 \\
5530-03\end{array}$ & $\begin{array}{l}5426-03 \\
5426-05 \\
5526-01\end{array}$ & 3 \\
\hline
\end{tabular}

a Pumping well

Figure 18. Water-management network wells and number of additional locations needed, Kauai, Hawaii, 1992. 


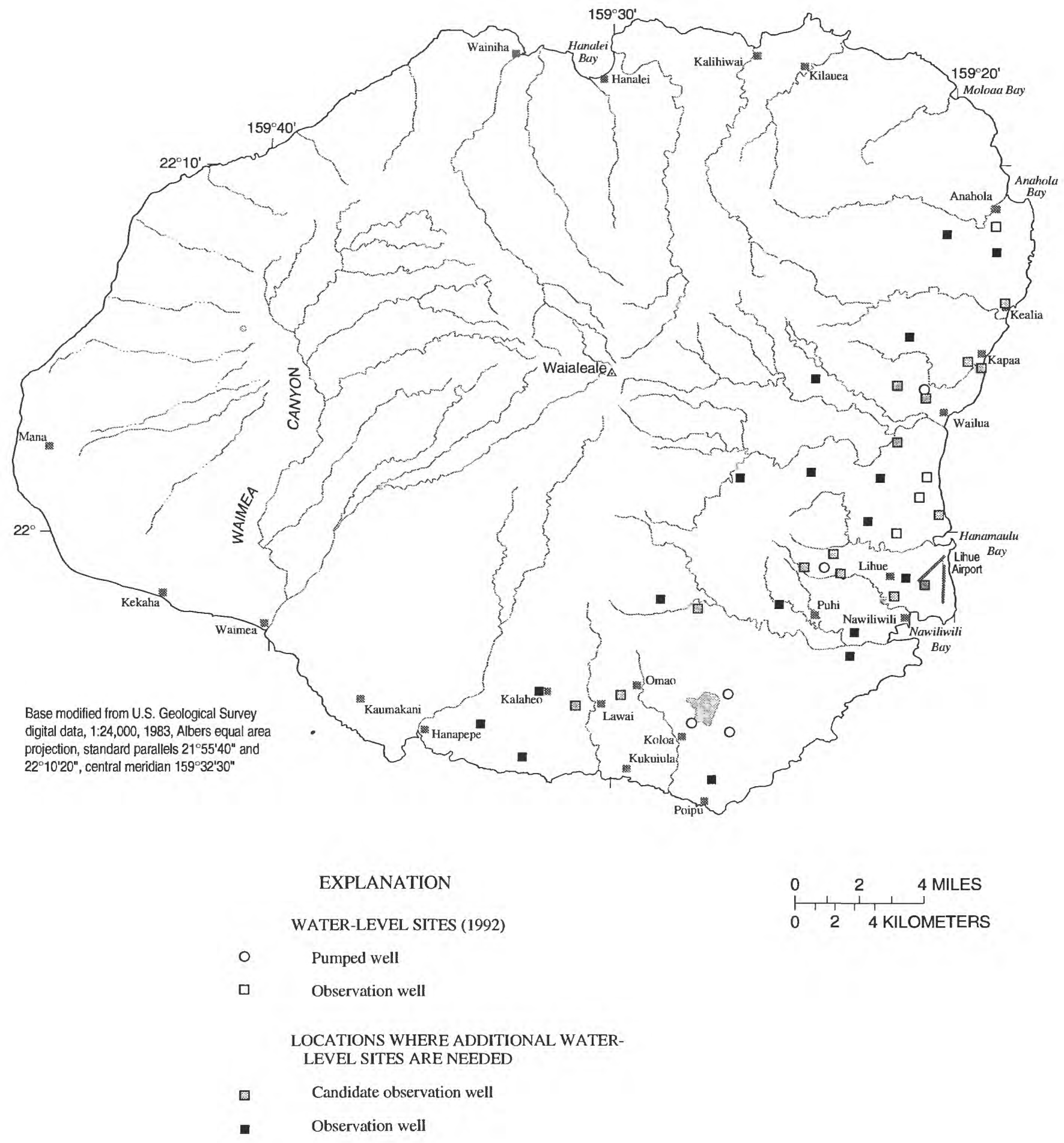

Figure 19. Water-level data-collection sites (1992) classified as water-management wells and locations where additional wells are needed for water-level data, Kauai, Hawaii. 


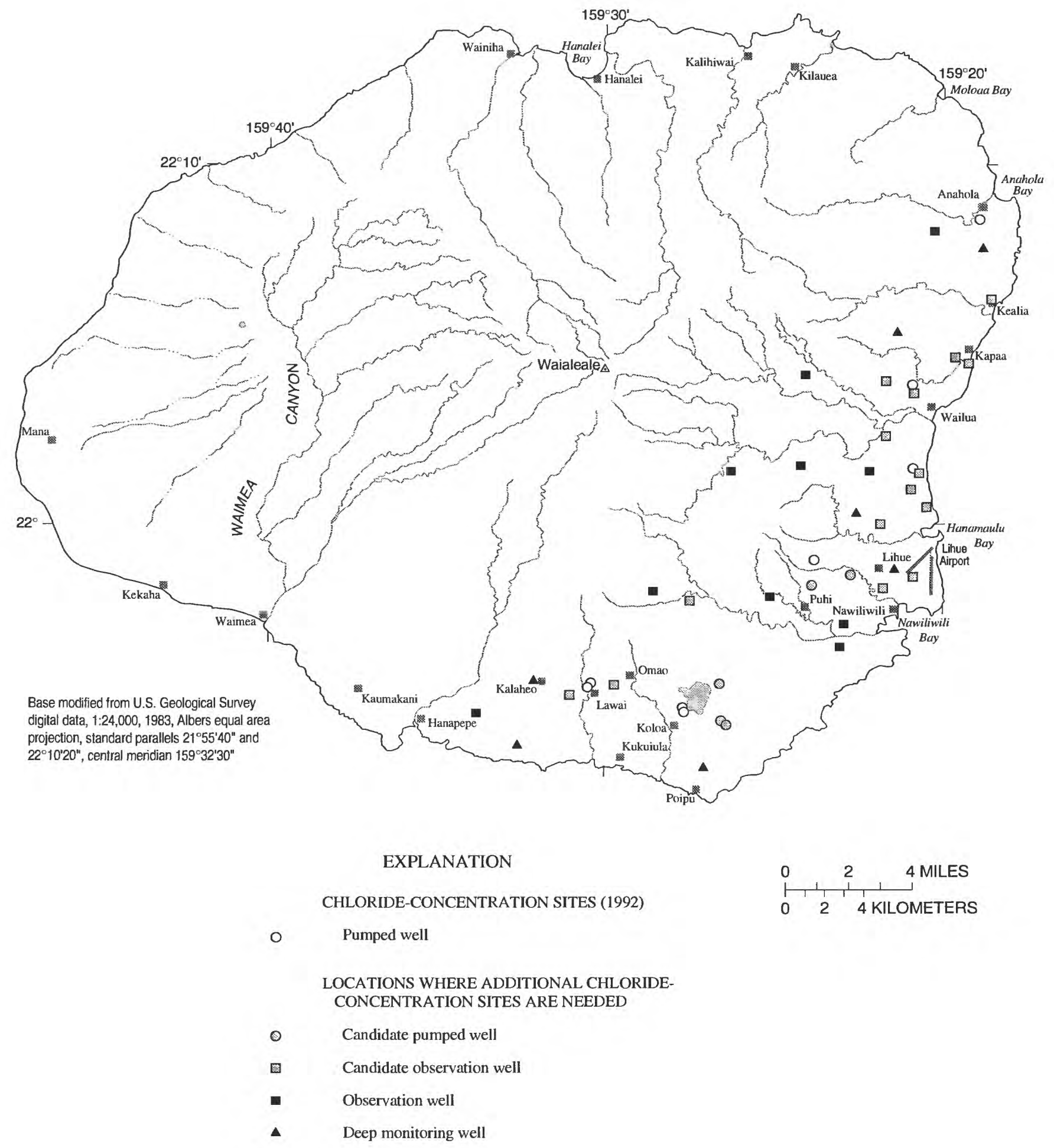

Figure 20. Chloride-concentration data-collection sites (1992) classified as water-management wells and locations where additional wells are needed for chloride-concentration data, Kauai, Hawaii. 
data (figs. 18 and 20). No deep monitoring wells exist in the Lihue area to monitor the vertical movement of the zone of transition between freshwater and saltwater. Locations where deep monitoring wells and observation wells open to the producing zone are needed for chloride-concentration data are shown in figure 20 . The observation well locations are the same as those needed for water-level data.

Kapaa.--The Kapaa area, which is bounded by the Wailua River to the south, Anahola Stream to the north, and the Makaleha Mountains to the west, is a rapidly growing part of the island. The Makaleha Mountains, and Nonou and Puu Ehu ridges, which are composed of lava flows of the Napali Member, are prominent features in the area. The more gentle slopes bordering the mountains and ridges are underlain by lava flows of the Koloa Volcanics. Basal and high-level water occurs in the lava flows of the Napali Member. Basal-water heads range from 14 to $67 \mathrm{ft}$ in wells at the bottom of the east slope of Nonou and Puu Ehu ridges, and Makaleha Mountains. The relatively high heads are probably caused by the impounding effect of the less permeable lavas of the Koloa Volcanics which were deposited against the eroded and weathered surface of the Napali Member (Macdonald and others, 1960). In the coastal areas, lava flows of the Koloa Volcanics contain basal water with heads ranging from 6 to $13 \mathrm{ft}$. Basal water in the lavas of the Napali Member probably discharges into the overlying Koloa Volcanics owing to lower water levels in the Koloa Volcanics as compared with the underlying Napali Member (Macdonald and others, 1960). High-level water impounded by dikes occurs in the Napali Member of the Makaleha Mountains. Water levels in these high-level water bodies range from 360 to $574 \mathrm{ft}$ above mean sea level.

In 1992, the DOW pumped an average of $2 \mathrm{Mgal} / \mathrm{d}$ in the Kapaa area. The Lihue Plantation pumped an average of $0.4 \mathrm{Mgal} / \mathrm{d}$. Almost two-thirds of this water was withdrawn from high-level water bodies in the Makaleha Mountains. The demand for potable water in the Kapaa area is projected to increase by $2.7 \mathrm{Mgal} / \mathrm{d}$ by the year 2011 (State of Hawaii, Commission on Water Resource Management, 1992b).

Water-level measurements were made by the USGS in one observation well in the Kapaa area in 1992 (fig. 13 and table 3). This well, near Anahola, was classified as a water-management well for the collection of water-level data. In addition, water-level measurements were made in the DOW pumped wells near the base of Nonou ridge (fig. 13 and table 3). These wells were temporarily classified as water-management wells for the collection of water-level data (fig. 18); however, the existing water-level data from these wells need to be evaluated to determine if residual drawdowns due to pumping are a significant component of the water levels measured. If these wells are not suitable for measuring water levels, a nearby DOW well (0320-02), which is presently unused, may be a suitable replacement. Locations where additional observation wells are needed for water-level data are shown in figure 19. Although not shown in figure 19 , two observation wells are needed at three or more of these locations to determine the occurrence and movement of ground water in the high-level and basal-water bodies; one in the Koloa Volcanics and one in the underlying Waimea Canyon Basalt. Water levels will need to be measured at various depths during the drilling of the observation wells, and a detailed record of drill cuttings will be needed to identify possible perching units in the Koloa Volcanics, and the contact between the Koloa Volcanics and Waimea Canyon Basalt. Candidate wells for inclusion in the water-management network are listed in figure 18.

Water-quality samples were collected by the USGS from four pumped wells in the Kapaa area (fig. 15 and table 3), all of which were classified as watermanagement wells for the collection of chloride-concentration data (fig. 18). No deep monitoring wells exist in the Kapaa area to monitor the vertical movement of the zone of transition between freshwater and saltwater. Locations where deep monitoring wells and observation wells open to the producing zone are needed for chloride-concentration data are shown in figure 20 . The observation well locations are the same as those needed for water-level data.

Koloa.--The Koloa area, which includes the popular tourist destination at Poipu, is bounded by Haupu ridge to the northeast, the high central mountains of the island to the north, and the Hanapepe River to the west. Lavas of the Koloa Volcanics are exposed in the southern part of the area. The lavas of the Napali Member are exposed in the northern part of the area and along the southwest slopes of Haupu ridge. The lava flows of the Napali Member contain basal water with heads ranging from 30 to $120 \mathrm{ft}$ above sea level. The high heads are probably the result of impounding effects of the rocks of the Koloa Volcanics which lie on the weathered surface of the Napali Member (Macdonald and others, 1960). 
Basal water in the Koloa Volcanics is developed with Maui-type wells in the valley of Lawai Stream and Hanapepe River.

In 1992, the DOW pumped an average of 3.1 $\mathrm{Mgal} / \mathrm{d}$ in the Koloa area. The McBryde Sugar Co. pumped an average of $1.8 \mathrm{Mgal} / \mathrm{d}$. The demand for potable water in the Koloa area is projected to increase by $3.3 \mathrm{Mgal} / \mathrm{d}$ by the year 2011 (State of Hawaii, Commission on Water Resource Management, 1992b).

Water-level measurements were made by the USGS in three pumped wells (table 3) near Waita reservoir in the Koloa area in 1992 (fig. 14). These wells were temporarily classified as water-management wells for the collection of water-level data (fig. 18); however, the existing water-level data from these wells need to be evaluated to determine if residual drawdowns due to pumping are a significant component of the water levels measured. Locations where observation wells are needed for water-level data in the Napali Member are shown in figure 19. Candidate wells for inclusion in the water-management network are listed in figure 18.

Water-quality samples were collected by the USGS from four pumped wells in 1992 (fig. 15 and table 3). All of these wells were classified as watermanagement wells for the collection of chloride-concentration data (fig. 18). To monitor the chloride concentration of basal water withdrawn from the area near Waita reservoir, pumped wells 5426-03, -05 , and 552601 were identified as candidate water-management wells. No deep monitoring wells exist in the Koloa area to monitor the vertical movement of the zone of transition between freshwater and saltwater. Locations where deep monitoring wells and observation wells open to the producing zone are needed for chloride-concentration data are shown in figure 20 . The observation well locations are the same as those needed for water-level data.

\section{Maui}

The island of Maui consists of two coalesced shield volcanoes. The broad gently sloping plain connecting the two volcanoes was formed when lava of the East Maui Volcano (Haleakala) banked against the already existing West Maui Volcano (Stearns and Macdonald, 1942) (fig. 21). The rocks of the West Maui Volcano have been divided into the Wailuku Basalt (oldest), Honolua Volcanics, and Lahaina Volcanics (youngest) (Langenheim and Clague, 1987), representing the shield stage and postshield caldera-filling phase, the postshield stage, and the rejuvenated stage, respectively (Stearns and Macdonald, 1942). The water-bearing rocks of West Maui are the thin-bedded lavas of the Wailuku Basalt. Covering the Wailuku Basalt in many areas are the lava flows of the Honolua Volcanics.

These lava flows have relatively low permeability and are generally too discontinuous to function as waterbearing units. The deposits of the Lahaina Volcanics are not extensive enough to be important water-bearing units.

The rocks of the East Maui Volcano have been divided into the Honomanu Basalt (oldest), Kula Volcanics, and Hana Volcanics (youngest) (Langenheim and Clague, 1987), representing the shield, postshield, and rejuvenated stage, respectively (Stearns and Macdonald, 1942). The Honomanu Basalt, which forms the principal water-bearing rocks of the volcano, is buried almost completely by the Kula and Hana Volcanics. The Kula Volcanics is, however, geohydrologically important because in places it retards ground-water flow while in others it acts as a water-bearing unit. Like the Honomanu Basalt, the Hana Volcanics is highly permeable especially in the eastern part of the volcano.

In 1992, the USGS ground-water data-collection program consisted of 14 observation wells, one deep monitoring well, and 21 pumped wells (table 4). Water levels were measured at about 6- to 8-week intervals in 10 of the observation wells, and continuously in 4 of the observation wells (5430-05, 5431-01, 5631-02, and 5840-01) (fig. 22 and table 4). Water-quality samples were collected at about 6- to 8-week intervals from 21 pumped wells, and the one deep monitoring well (543005) (fig. 23 and table 4). Because wells were not being pumped during each site visit, the record of water-quality data is incomplete for 11 of the 21 pumped wells sampled (table 4). Well depth is not known for six of the pumped wells: 4825-01, 4937-01, 5330-11, 5424-01, 5522-01, and 5640-01.

Ground-water pumpage on the island of Maui averaged about $78 \mathrm{Mgal} / \mathrm{d}$ in 1992 on the basis of data reported to the CWRM. Most of the water pumped, 13 $\mathrm{Mgal} / \mathrm{d}$ in Lahaina and $37 \mathrm{Mgal} / \mathrm{d}$ in central Maui, was brackish and was used for sugarcane, golf courses, and landscaping. The remainder of this water, $28 \mathrm{Mgal} / \mathrm{d}$, was potable and was used for domestic or municipal purposes. The demand for potable water is projected to 


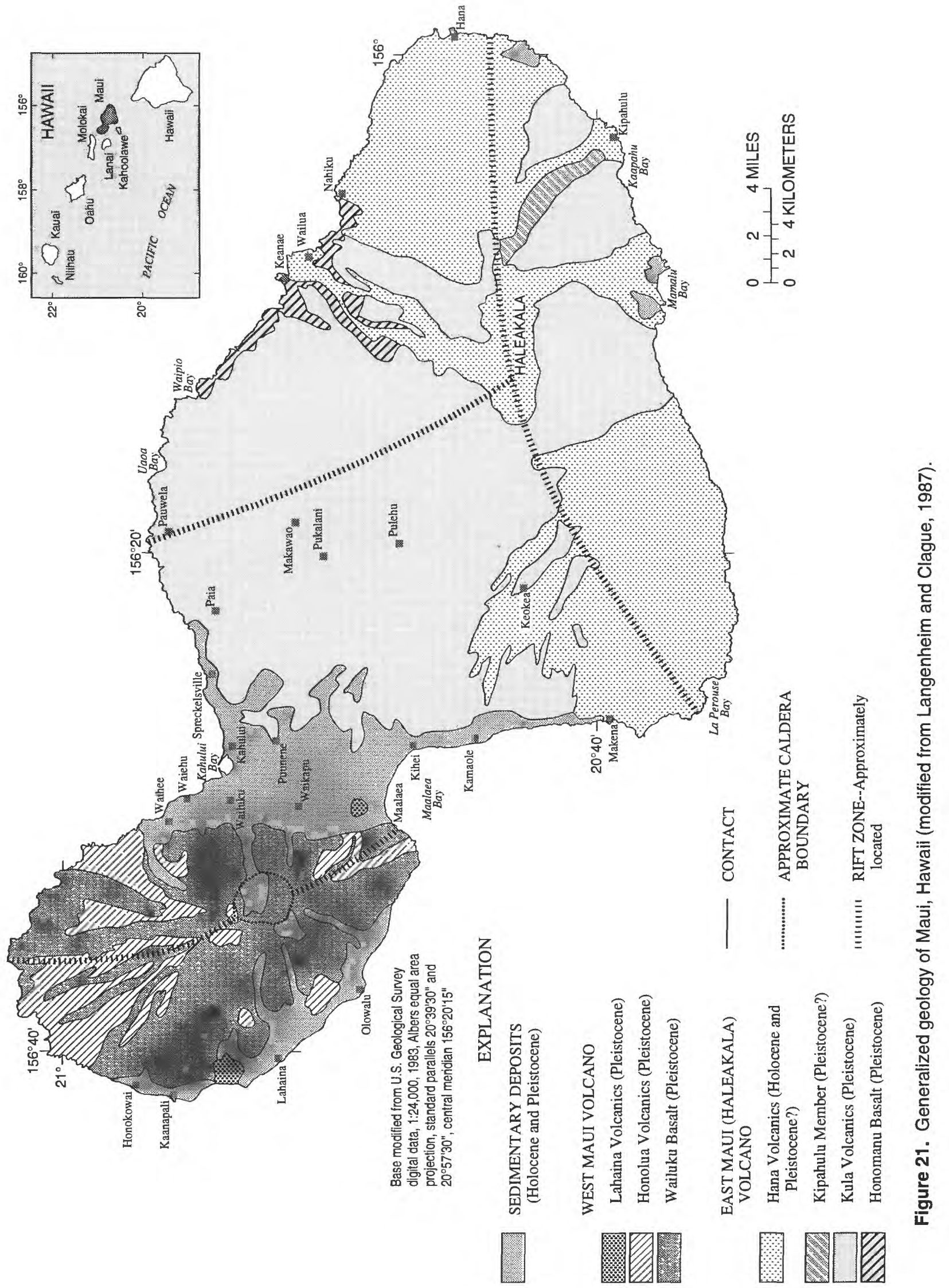




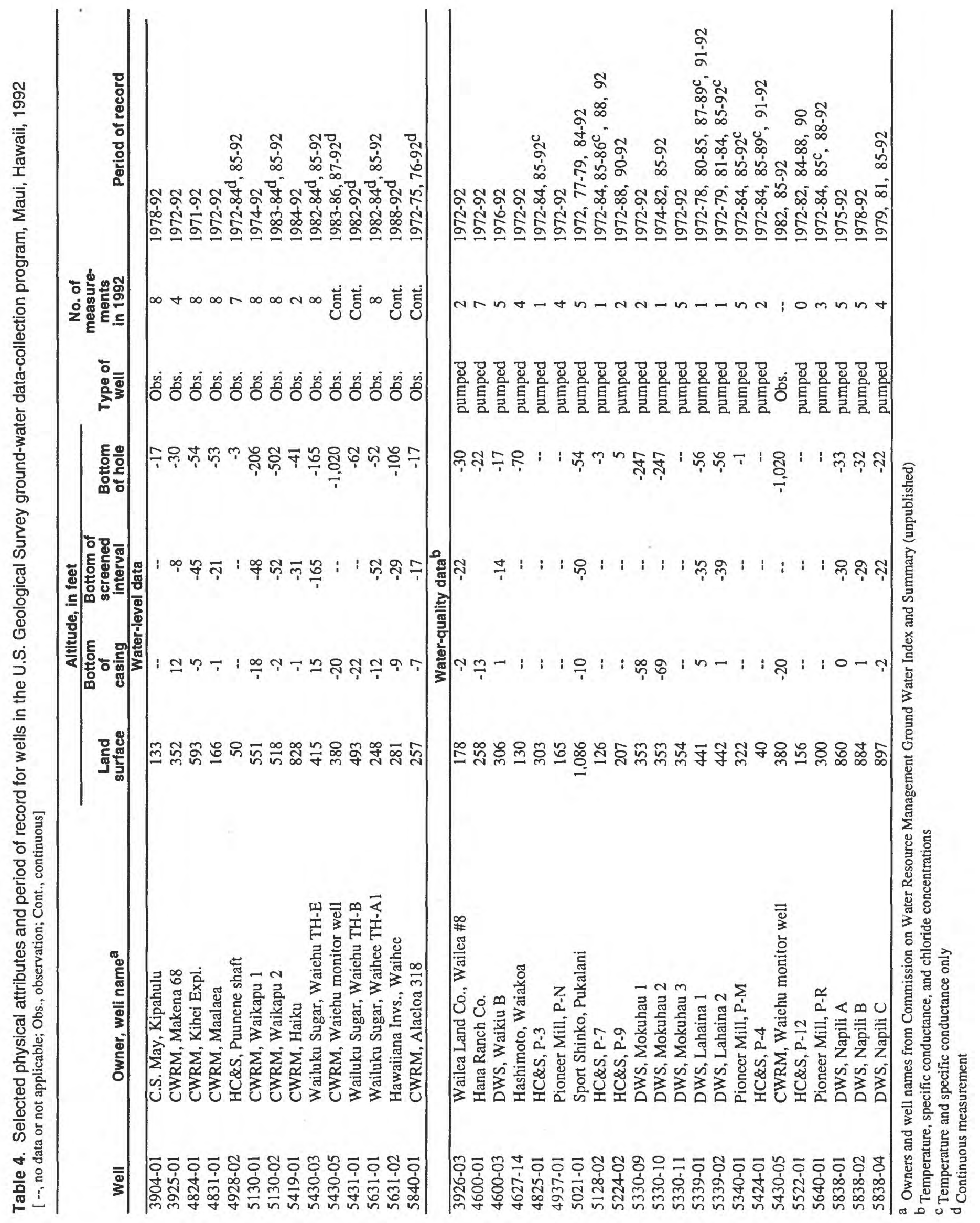




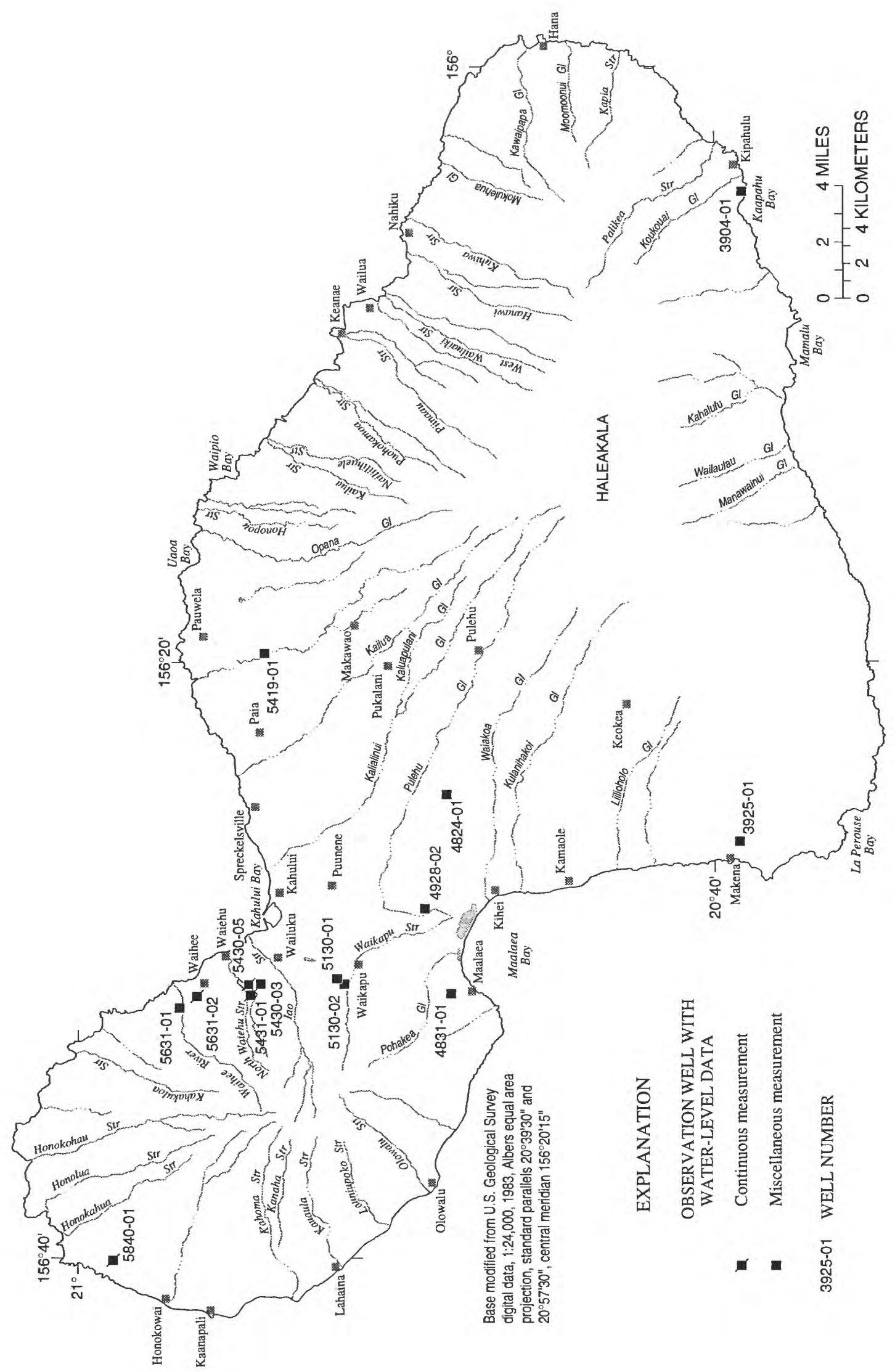

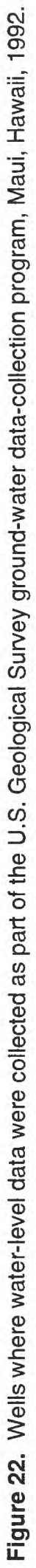




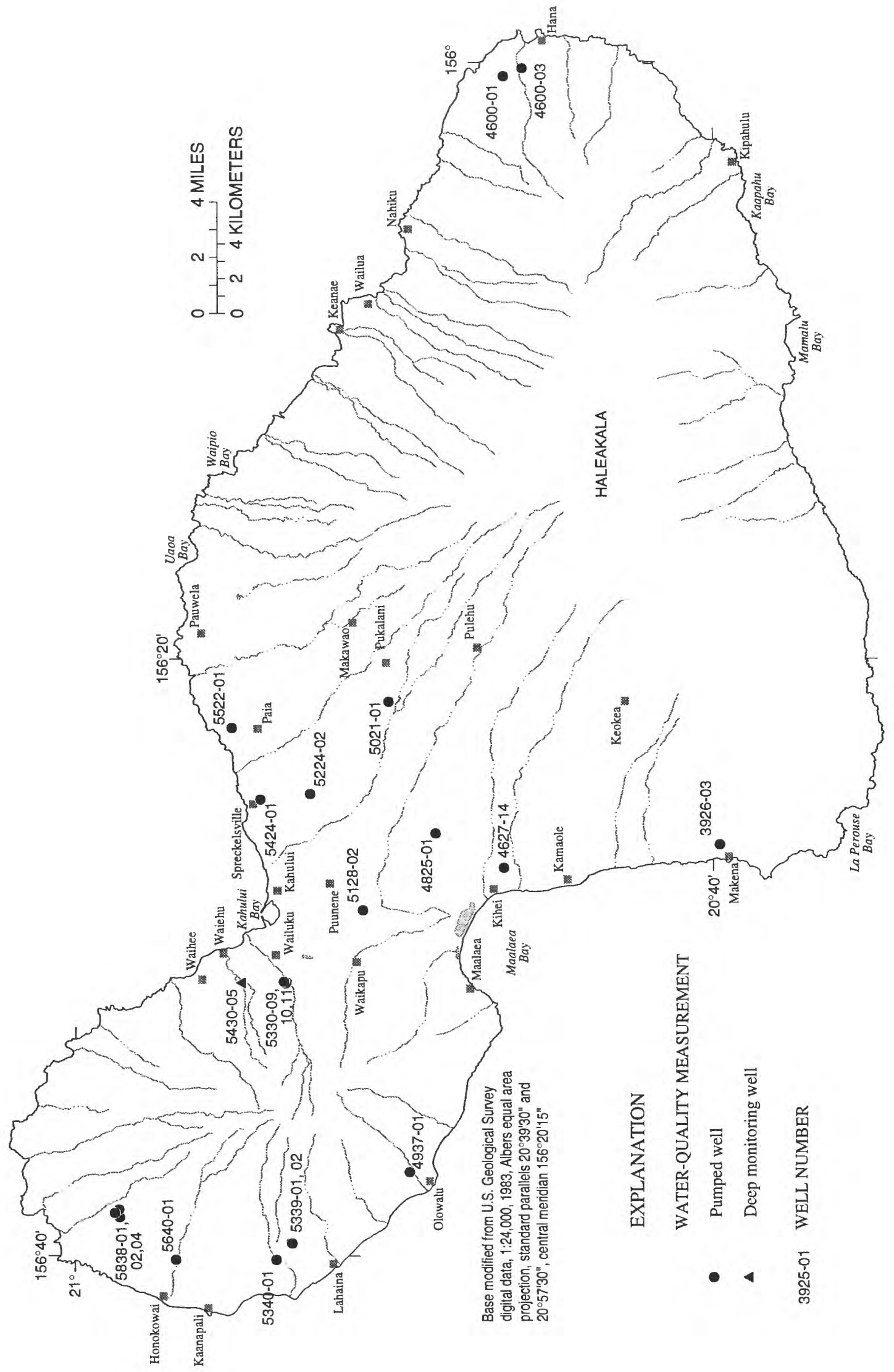

ภำ 
increase by more than $30 \mathrm{Mgal} / \mathrm{d}$ by the year 2010 (State of Hawaii, Commission on Water Resource Management, 1992c). The Department of Water Supply (DWS) systems are presently at the limit of supply capacity. The distribution and magnitude of pumpage (fig. 24) and the distribution of proposed wells (fig. 25) indicate a need for water-management networks in the Wailuku, Lahaina, and central Maui areas of the island. Wells needed to meet the objectives of a water-management network in these areas are described below.

Wailuku.--The Wailuku area is on the eastern slopes of the West Maui Volcano between Waikapu Stream and Waihee River. This area is the source of potable water for the Wailuku-Kahului and the KiheiMakena parts of the island. In 1992 the DWS pumped an average of $19.7 \mathrm{Mgal} / \mathrm{d}$ from basal and dikeimpounded water bodies in the Wailuku area. Most of the wells are concentrated between Iao and Waiehu Streams (fig. 24). Water levels in the basal-water body range from less than $3 \mathrm{ft}$ to about $30 \mathrm{ft}$ above mean sea level owing to a thick wedge of sedimentary deposits (caprock) extending from Waihee River to Maalaea. The demand for water in the Wailuku-Kahului and the Kihei-Makena parts of the island is projected to increase by $13 \mathrm{Mgal} / \mathrm{d}$ by the year 2010 (State of Hawaii, Commission on Water Resource Management, 1992c). In addition to the five wells proposed near the Waihee River (fig. 25), future ground-water development is anticipated in the area between Iao and Waikapu Streams.

Water-level measurements were made by the USGS in seven observation wells in the Wailuku area in 1992 (fig. 22 and table 4). These wells were classified as water-management wells for the collection of waterlevel data (fig. 26); however, the distribution of observation wells is not sufficient to contour water-level data in the area between Iao and Waikapu Streams and between Waiehu Stream and Waihee River (fig. 22). Locations where additional observation wells are needed for water-level data are shown in figure 27.

Water-quality samples were collected by the USGS from the deep monitoring well near Waiehu Stream and the three pumped wells near Iao Stream in 1992 (fig. 23 and table 4). These wells were classified as water-management wells for the collection of chloride-concentration data (fig. 26). The DWS Waiehu pumped wells $(5431-02,-03,-04)$ were identified as candidate water-management wells to monitor the chlo- ride concentration of water withdrawn from the basalwater body near Waiehu Stream (fig. 26). Locations where an additional deep monitoring well and observation wells open to the producing zone are needed for chloride-concentration data are shown in figure 28 . The observation well locations are the same as those needed for water-level data.

Lahaina.--The Lahaina area is located on the western slopes of the West Maui Volcano. The primary source of ground water in the area is a thin basal-water body, with water levels that range from less than $2 \mathrm{ft}$ to a maximum of $10 \mathrm{ft}$ above mean sea level. In 1984, Pioneer Mill Co. pumped an annual average of $33.5 \mathrm{Mgal} / \mathrm{d}$ of brackish ground water for sugarcane in the Lahaina area. However, the amount of ground water used to irrigate sugarcane has been declining as sugarcane acreage has been reduced. By 1992, Pioneer Mill Co. had reduced its average annual withdrawal of ground water to $10.6 \mathrm{Mgal} / \mathrm{d}$. Brackish ground water also is used for golf courses and landscaping in the area.

In 1992, the DWS pumped an average of 4.3 $\mathrm{Mgal} / \mathrm{d}$ from eight sources in the Lahaina area. Private purveyors pumped an average of $2.4 \mathrm{Mgal} / \mathrm{d}$ from four sources in 1992. The demand for potable water in the area is projected to increase by $6 \mathrm{Mgal} / \mathrm{d}$ by the year 2010 (State of Hawaii, Commission on Water Resource Management, 1992c). Seven additional pumped wells are proposed in the area (fig. 25). The chloride concentration of water withdrawn from this area often exceeds $250 \mathrm{mg} / \mathrm{L}$. A reduction in recharge from irrigation return flow owing to a decline in sugarcane acreage may affect ground-water availability and quality in the area.

Potable ground-water withdrawals are concentrated near Lahaina, Kaanapali, and Kapalua (fig. 24). After the construction of well fields proposed between Honokowai and Kanaha Streams (fig. 25), potable ground-water withdrawals will be distributed evenly between Lahaina and Kapalua at a distance of 2 to $3 \mathrm{mi}$ from shore. Brackish ground-water withdrawals are concentrated between Kaanapali and Olowalu at a distance of less than $2 \mathrm{mi}$ from shore.

Water-level measurements were made by the USGS in only one observation well in 1992 (fig. 22). This well, 5840-01, was classified as a water-management well for the collection of water-level data (fig. 26). Locations where additional observation wells are needed for water-level data are shown in figure 27. One of these locations represents a Maui-type well (5640- 


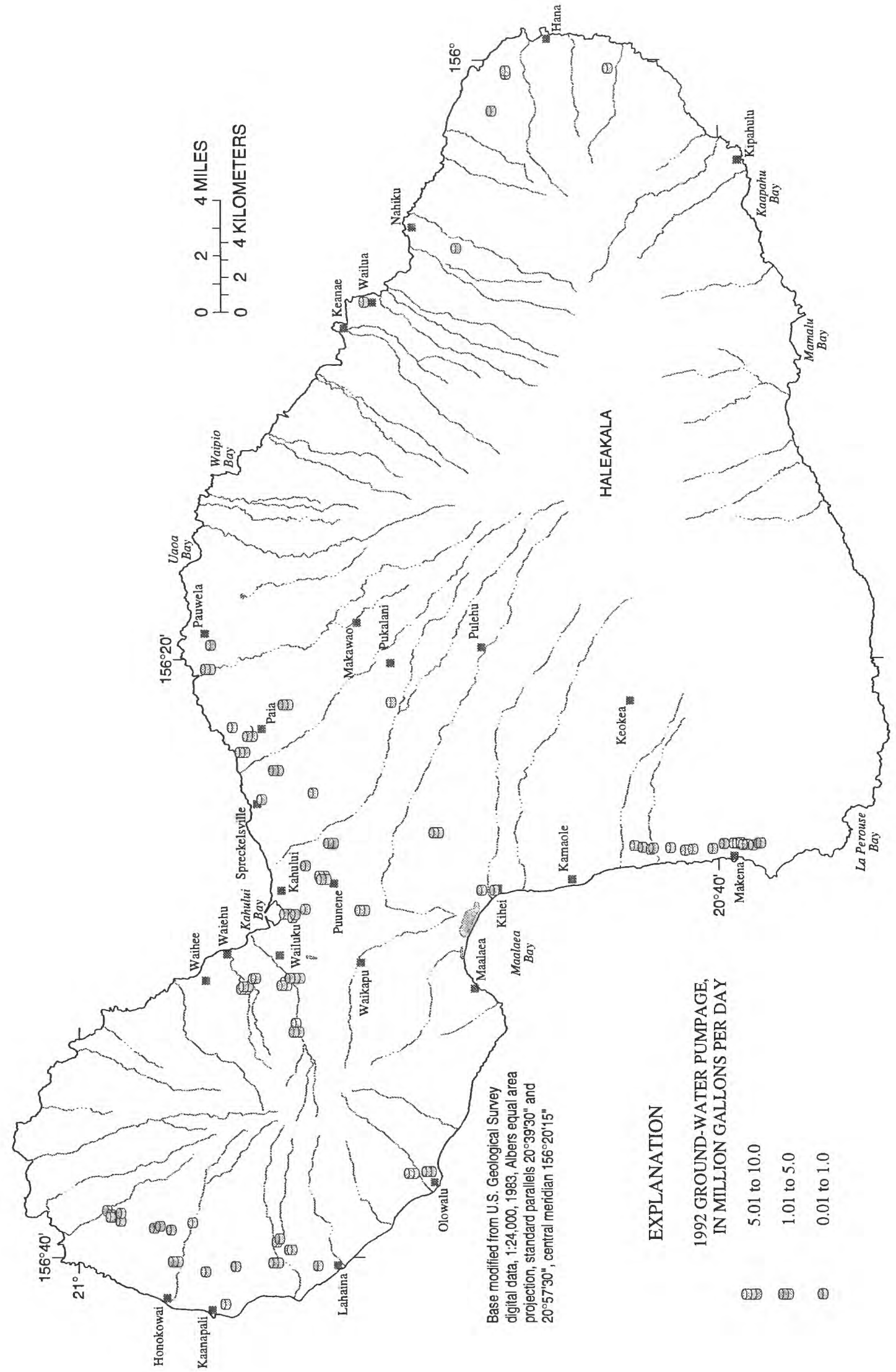

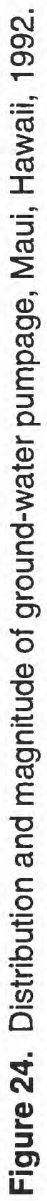




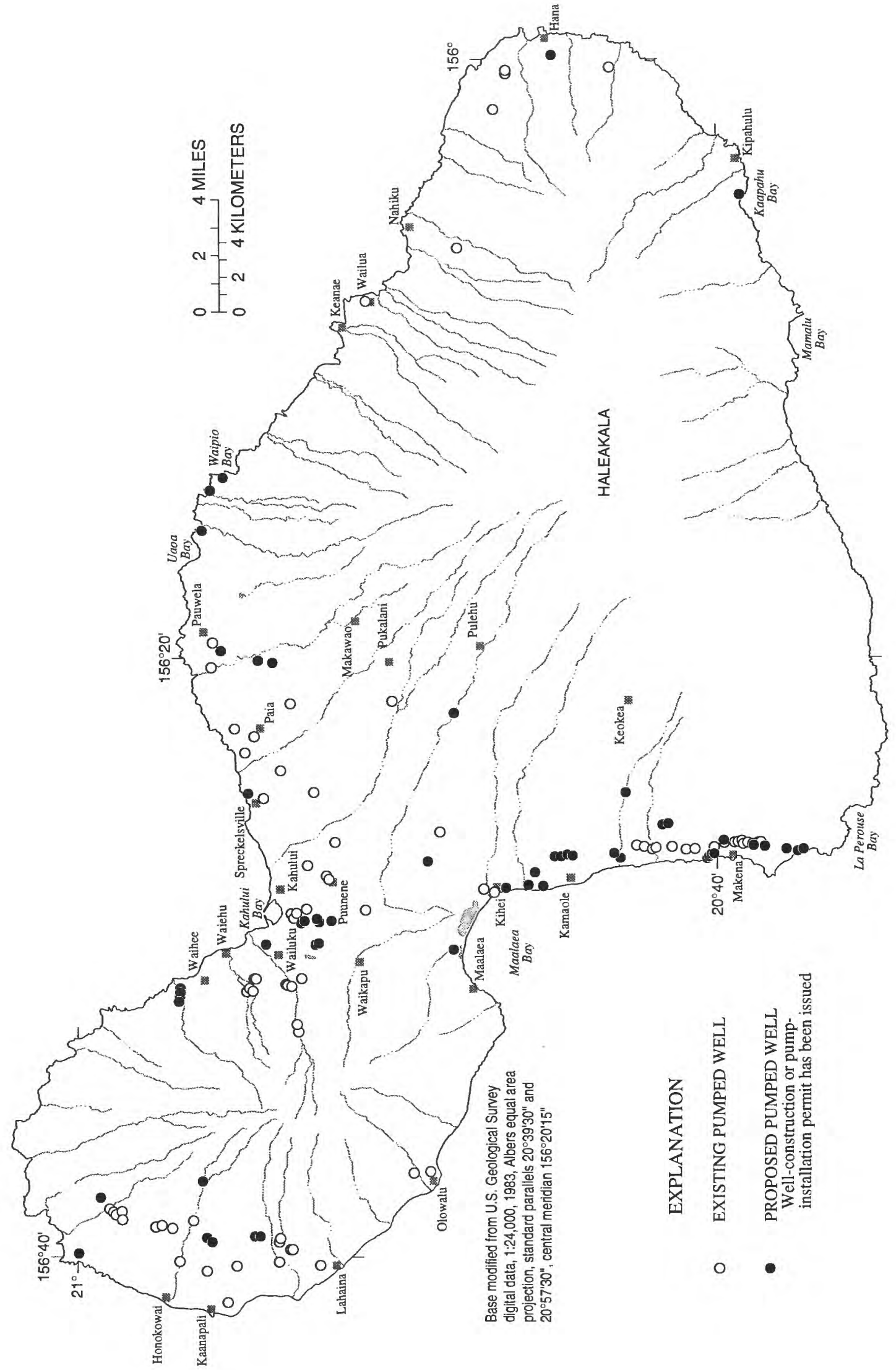

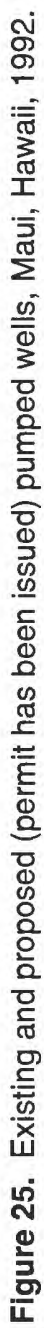




\begin{tabular}{|c|c|c|c|c|c|c|}
\hline \multirow[b]{2}{*}{$\begin{array}{l}\text { Type of data } \\
\text { collected }\end{array}$} & \multirow[b]{2}{*}{ Well type } & \multirow{2}{*}{\multicolumn{2}{|c|}{$\begin{array}{c}1992 \\
\text { PROGRAM }\end{array}$}} & \multicolumn{3}{|c|}{$\begin{array}{c}\text { ADDITIONAL } \\
\text { LOCATIONS NEEDED } \\
\end{array}$} \\
\hline & & & & & didate & $\begin{array}{c}\text { Total } \\
\text { number needed }\end{array}$ \\
\hline \multicolumn{7}{|c|}{ Wailuku } \\
\hline Water level & Observation & $\begin{array}{l}5130-01 \\
5130-02 \\
5431-01 \\
5430-03\end{array}$ & $\begin{array}{l}5631-01 \\
5631-02 \\
5430-05\end{array}$ & & & 3 \\
\hline \multirow[t]{3}{*}{ Chloride } & Observation & & & $\begin{array}{l}5130-01 \\
5130-02 \\
5431-01 \\
\end{array}$ & $\begin{array}{l}5430-03 \\
5631-01 \\
5631-02 \\
\end{array}$ & 9 \\
\hline & Deep monitoring & $5430-05$ & & & & 1 \\
\hline & Pumped & $\begin{array}{l}5330-09 \\
5330-10 \\
5330-11\end{array}$ & & $\begin{array}{l}5431-02 \\
5431-03 \\
5431-04\end{array}$ & & 3 \\
\hline \multicolumn{7}{|c|}{ Lahaina } \\
\hline Water level & Observation & $5840-01$ & & $\begin{array}{l}5341-01 \\
5640-01^{a} \\
5641-01\end{array}$ & & 10 \\
\hline \multirow[t]{3}{*}{ Chloride } & Observation & & & $\begin{array}{l}5341-01 \\
5641-01 \\
5840-01 \\
\end{array}$ & & 10 \\
\hline & Deep monitoring & & & & & 3 \\
\hline & Pumped & $\begin{array}{l}5339-01 \\
5339-02 \\
5340-01 \\
5640-01 \\
\end{array}$ & $\begin{array}{l}5838-01 \\
5838-02 \\
5838-04\end{array}$ & $\begin{array}{l}5739-01 \\
5739-02\end{array}$ & & 2 \\
\hline \multicolumn{7}{|c|}{ Central Maui } \\
\hline Water level & Observation & $\begin{array}{l}3925-01 \\
4824-01 \\
4831-01 \\
4928-02 \\
5419-01 \\
\end{array}$ & & $\begin{array}{l}4627-14^{\mathrm{a}} \\
5128-02^{\mathrm{a}} \\
5224-02^{\mathrm{a}}\end{array}$ & & 13 \\
\hline \multirow[t]{3}{*}{ Chloride } & Observation & & & $\begin{array}{c}3925-01 \\
4824-01 \\
4831-01 \\
4928-02 \\
5419-01\end{array}$ & & $14 *_{-}$ \\
\hline & Deep monitoring & & & & & 1 \\
\hline & Pumped & $\begin{array}{l}3926-03 \\
4627-14 \\
4825-01 \\
5021-01 \\
5224-02 \\
5522-01 \\
5128-02 \\
5424-01\end{array}$ & & $\begin{array}{l}5227-04 \\
5226-02\end{array}$ & & 2 \\
\hline
\end{tabular}

a Pumping well

Figure 26. Water-management network wells and number of additional locations needed, Maui, Hawaii, 1992. 


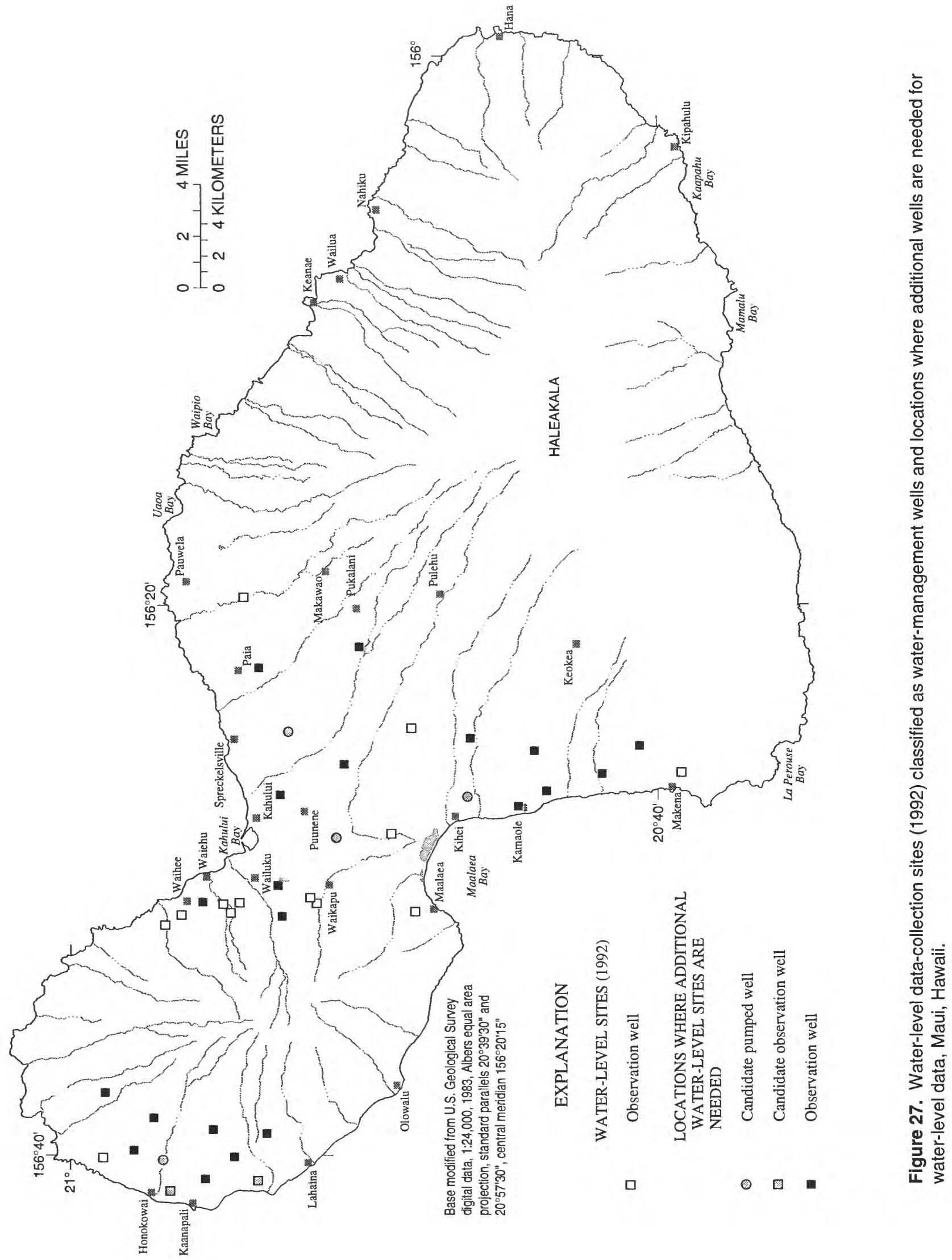




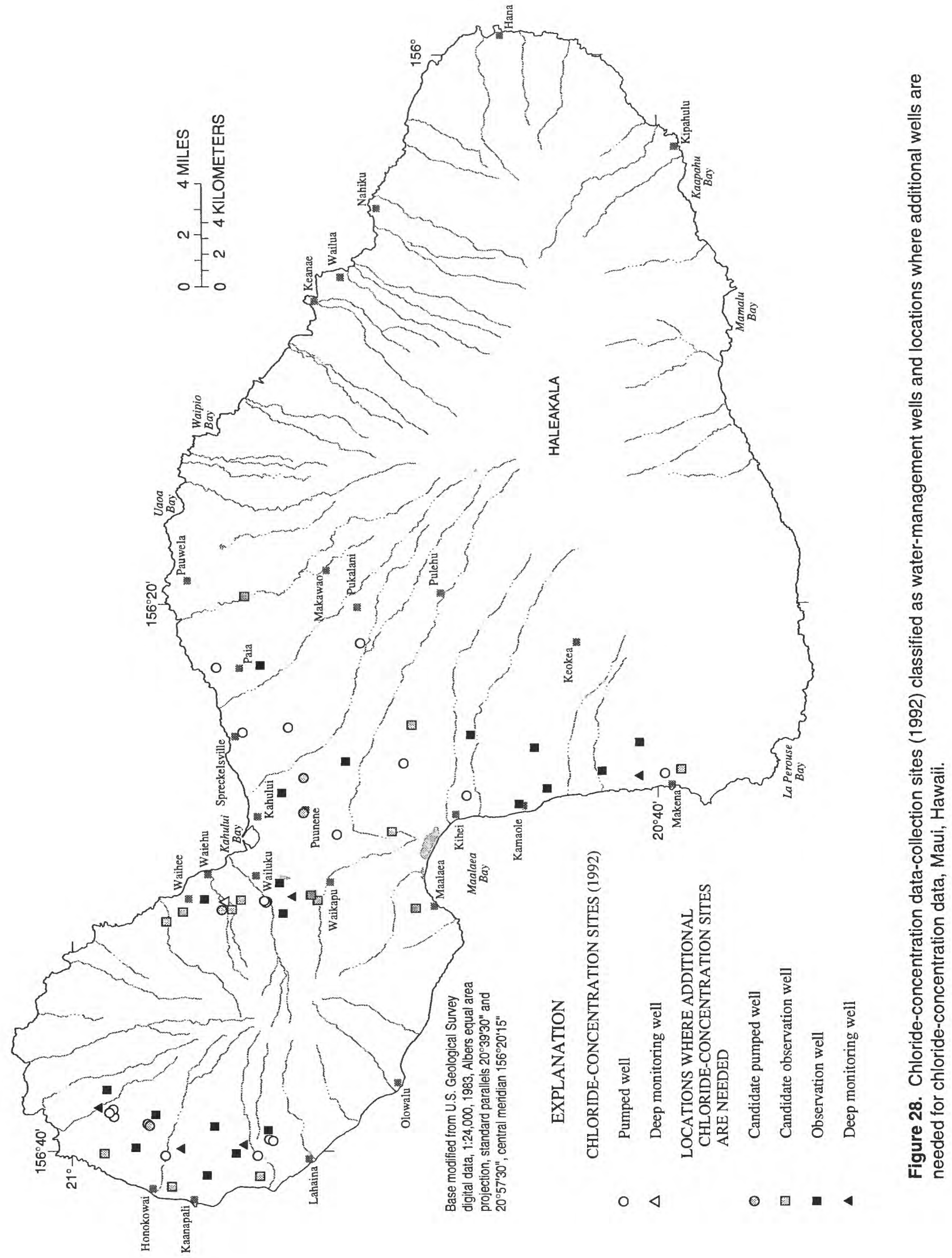


01) which is suitable for water-level measurement when the pump is off. Candidate wells for inclusion in the water-management network are listed in figure 26.

Water-quality samples were collected by the USGS from eight pumped wells in 1992 (fig. 23 and table 4). All of these wells were classified as watermanagement wells for the collection of chloride-concentration data (fig. 26). The Kaanapali Water Corporation pumped wells (5739-01 and 5739-02) were identified as candidate water-management wells to monitor the chloride concentration of water withdrawn from the basal-water body in the area north of Honokowai Stream. The only observation well in the program in the Lahaina area, well 5840-01, also was identified as a candidate water-management well for the collection of chloride-concentration data (fig. 26). No deep monitoring wells exist to monitor the vertical movement of the zone of transition between freshwater and saltwater. Locations where deep monitoring wells and observation wells open to the producing zone are needed for chloride-concentration data are shown in figure 28. The observation well locations are the same as those needed for water-level data.

Central Maui.--The central Maui area is on the western slopes of the East Maui Volcano (Haleakala) and includes the isthmus, which lies between the East and West Maui Volcanoes. Sugarcane fields occupy about 34,000 acres in and upslope of the isthmus to an altitude of about 1,000 ft. In 1990 about $265 \mathrm{Mgal} / \mathrm{d}$ of surface water was imported from northeast and northwest Maui for irrigating sugarcane (P.J. Shade, U.S. Geological Survey, written commun., 1994). The Kihei-Makena part of the island along the western shore of East Maui is the site of extensive tourist and residential development.

Most ground water withdrawn from central Maui is brackish and used for sugarcane, golf courses, and landscaping. This water is derived from a thin basalwater body with water levels that range from less than 1 $\mathrm{ft}$ to about $5 \mathrm{ft}$ above mean sea level. In 1992 Hawaii Commercial \& Sugar (HC\&S) pumped an average of 33 $\mathrm{Mgal} / \mathrm{d}$ of brackish ground water for irrigating sugarcane in central Maui. Although the amount of water used to irrigate sugarcane in central Maui is not projected to change before the year 2010 (State of Hawaii, Commission on Water Resource Management, 1992c), the demand for water suitable for landscaping and golf courses is increasing between Kihei and Makena. In
$1992,3.0 \mathrm{Mgal} / \mathrm{d}$ of brackish ground water was withdrawn from 17 pumped wells for landscaping and golf courses between Kihei and Makena (fig. 24). To meet the increasing demand for water, 23 additional pumped wells are proposed between Kihei and Makena (fig. 25).

Water-level measurements were made by the USGS in five observation wells in the central Maui area in 1992 (fig. 22 and table 4). All of these wells were classified as water-management wells for the collection of water-level data (fig. 26). Locations where additional observation wells are needed for water-level data are shown in figure 27 . Three of these locations represent Maui-type wells which may be suitable for water-level data when the pumps are off.

Water-quality samples were collected by the USGS from eight pumped wells in 1992 (fig. 23 and table 4). All of these wells were classified as watermanagement wells for the collection of chloride-concentration data (fig. 26). The HC\&S pumped wells (5226-02 and 5227-04) were identified as candidate water-management wells to monitor the chloride concentration of water withdrawn from the northern part of the isthmus (fig. 26). No observation wells exist in the vicinity of pumped wells to monitor the lateral movement of saltwater. In addition, no deep monitoring wells exist to monitor the vertical movement of the zone of transition between freshwater and saltwater. Locations where deep monitoring wells and observation wells open to the producing zone are needed for chloride-concentration data are shown in figure 28 . The observation well locations are the same as those needed for waterlevel data.

\section{Molokai}

The island of Molokai consists of two coalesced volcanoes, the East Molokai and West Molokai Volcanoes (fig. 29). The gently sloping plain between the two volcanoes was formed when lava of the East Molokai Volcano banked against the already existing West Molokai Volcano. The rocks of the East Molokai Volcano are divided into the East Molokai Volcanics (oldest) and the Kalaupapa Volcanics (youngest). The East Molokai Volcanics is formed largely of basaltic lava flows (lower member), which have relatively high permeability compared with the thin cap of andesites (upper member). All the rocks of the West Molokai Volcano are called the West Molokai Volcanics and 

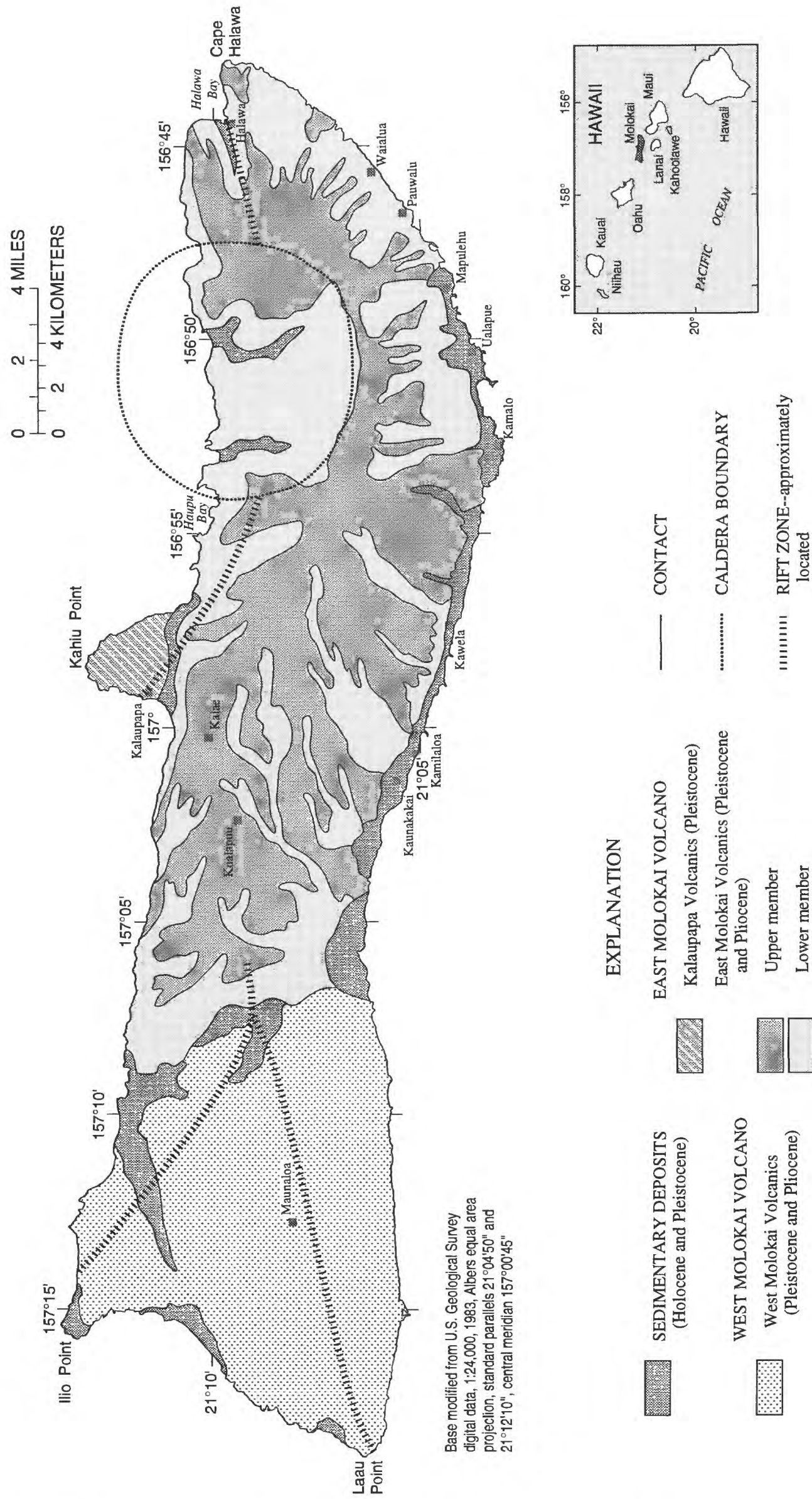

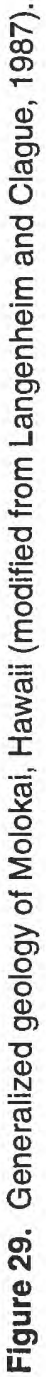


represent shield and postshield eruptive stages (Langenheim and Clague, 1987).

In 1992 the USGS ground-water data-collection program consisted of three observation wells and five pumped wells (fig. 30 and table 5). Water levels were measured at about 7-week intervals in all three of the observation wells and two of the pumped wells. Continuous water levels were not recorded at any wells. Water-quality samples were collected at about 7-week intervals from two of the pumped wells, and one of the observation wells (fig. 30). Monthly water-quality samples were furnished by the owners of three of the pumped wells (0801-01, -02, and 0901-01). Well depth is known for each well in the program (table 5).

Ground-water pumpage on the island of Molokai averaged about $5 \mathrm{Mgal} / \mathrm{d}$ in 1992 on the basis of data reported to the CWRM. The distribution and magnitude of pumpage are shown in figure 31. Basal water is withdrawn from four pumped wells located at an altitude of about $1,000 \mathrm{ft}$ in the area east of Kualapuu, and 10 pumped wells located at an altitude of less than $40 \mathrm{ft}$ along the south shore of eastern Molokai. Dikeimpounded water is withdrawn from three pumped wells in Waikolu Stream valley and one pumped well in Waihanau Stream valley. The demand for water, on the basis of intensive agricultural production and full urban development of available land owned by public agencies and private parties, is projected to increase from 5 to $43 \mathrm{Mgal} / \mathrm{d}$ (State of Hawaii, Commission on Water Resource Management, 1992d). The distribution of proposed pumped wells is shown in figure 32 .

Water-management networks are needed in the major source areas of potable ground water, which include the western part of the East Molokai Volcano near Kualapuu and along the south shore of the East Molokai Volcano between Kawela and Mapulehu. In addition, a water-management network is needed in Waikolu Stream valley to observe the effect of pumping dike-impounded water on ground-water levels and ground-water discharge to Waikolu Stream. Wells needed to meet the objectives of water-management networks in these areas are described below.

Kualapuu.--The Kualapuu area is located on the western slopes of the East Molokai Volcano. This area is the source of potable water for water systems operated by the DWS, Department of Hawaiian Home Lands (DHHL), and Kukui (Molokai) Inc. The average pumpage for 1992 was $1.3 \mathrm{Mgal} / \mathrm{d}$ from DWS pumped well 0801-03, $0.4 \mathrm{Mgal} / \mathrm{d}$ from DHHL pumped wells 0801-01 and -02, and 1.2 Mgal/d from Kukui (Molokai) Inc. pumped well 0901-01.

Water-level measurements were made by the USGS in two observation wells in the Kualapuu area in 1992 (fig. 30 and table 5). These wells, which are located in Kaunakakai Gulch between the Kualapuu pumped wells and the south shore of the island, were classified as water-management wells for the collection of water-level data (fig. 33). Locations where additional observation wells are needed for water-level data are shown in figure 34.

Water-quality samples were collected by the USGS from three pumped wells in 1992 (fig. 30 and table 5). These wells and the observation wells located in Kaunakakai Gulch were classified as water-management wells for the collection of chloride-concentration data (fig. 33). The DWS pumped well 0801-03 was identified as a candidate water-management well for the collection of chloride-concentration data (fig. 33). No deep monitoring wells exist to monitor the vertical movement of the zone of transition between freshwater and saltwater. Locations where deep monitoring wells and observation wells open to the producing zone are needed for chloride-concentration data are shown in figure 35. The observation well locations are the same as those needed for water-level data.

Kawela-Mapulehu.--The Kawela-Mapulehu area is located along the south shore of the East Molokai Volcano. Most ground-water withdrawals in the area are from the DWS Maui-type wells near Kawela (045701) and Ualapue (0449-01). The average pumpage for 1992 was $0.3 \mathrm{Mgal} / \mathrm{d}$ at the Kawela Maui-type well, and $0.2 \mathrm{Mgal} / \mathrm{d}$ at the Ualapue Maui-type well. Less than 0.5 $\mathrm{Mgal} / \mathrm{d}$ of water was pumped by private purveyors from six wells located between Kawela and Mapulehu.

Water-level measurements were made by the USGS in one observation well and two pumped wells in the Kawela-Mapulehu area in 1992 (fig. 30 and table 5). These wells, which are Maui-type wells, were classified as water-management wells for the collection of waterlevel data (fig. 33). Maui-type wells are suitable for water-level data when the pumps are off. Locations where additional observation wells are needed for water-level data are shown in figure 34.

Water-quality samples were collected by the USGS from two pumped wells in 1992 (fig. 30 and table 5). These wells, which are Maui-type wells near Kawela 


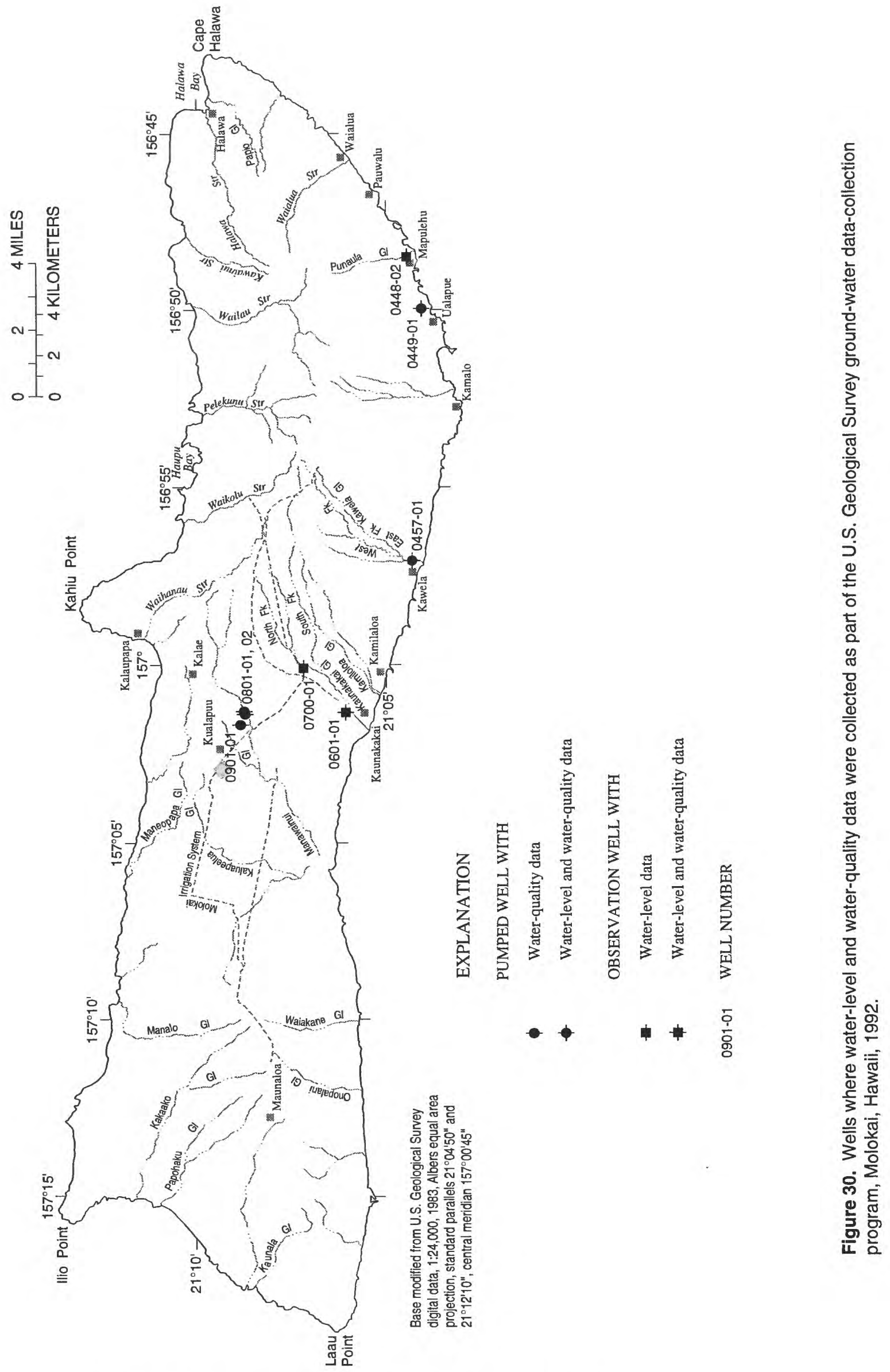




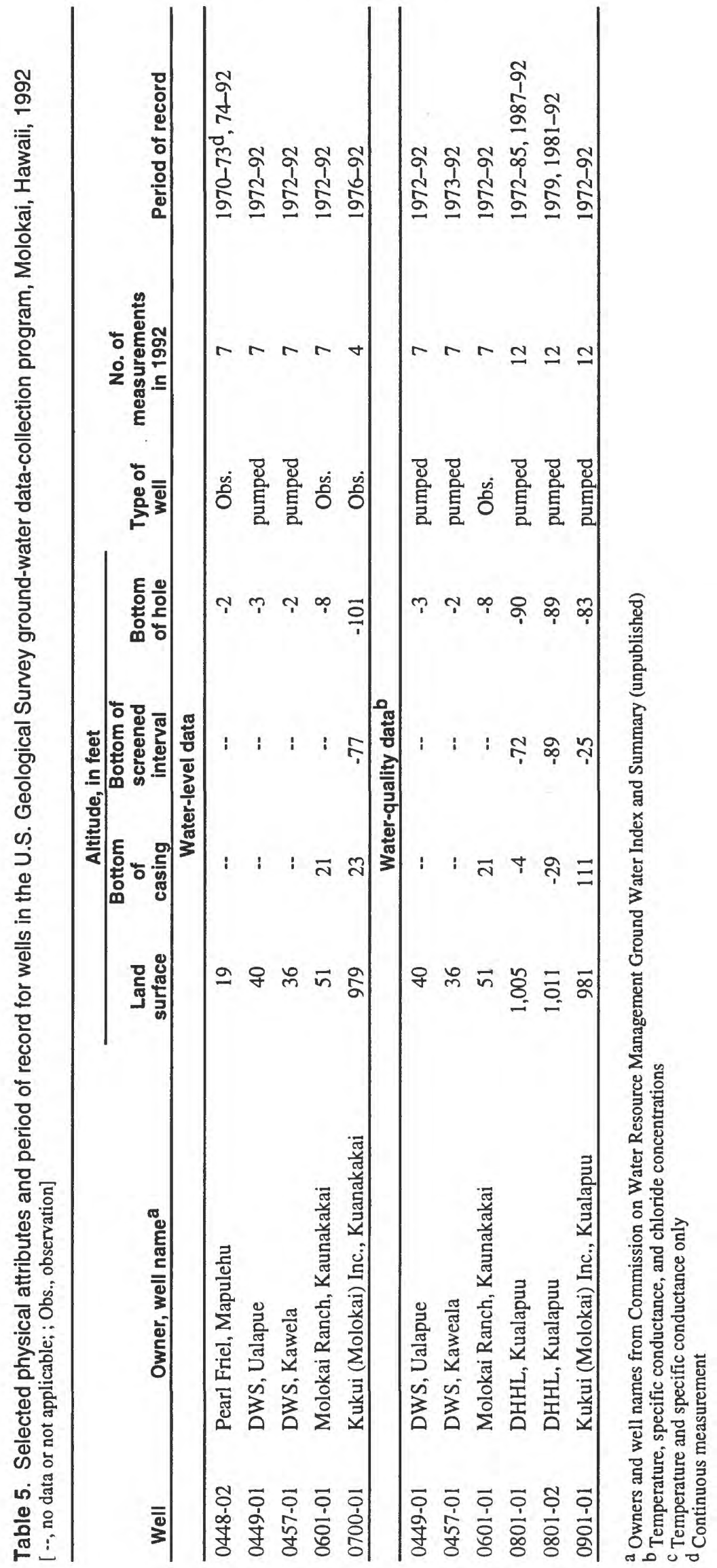

Evaluation of the Ground-Water Data-Collection Program 53 


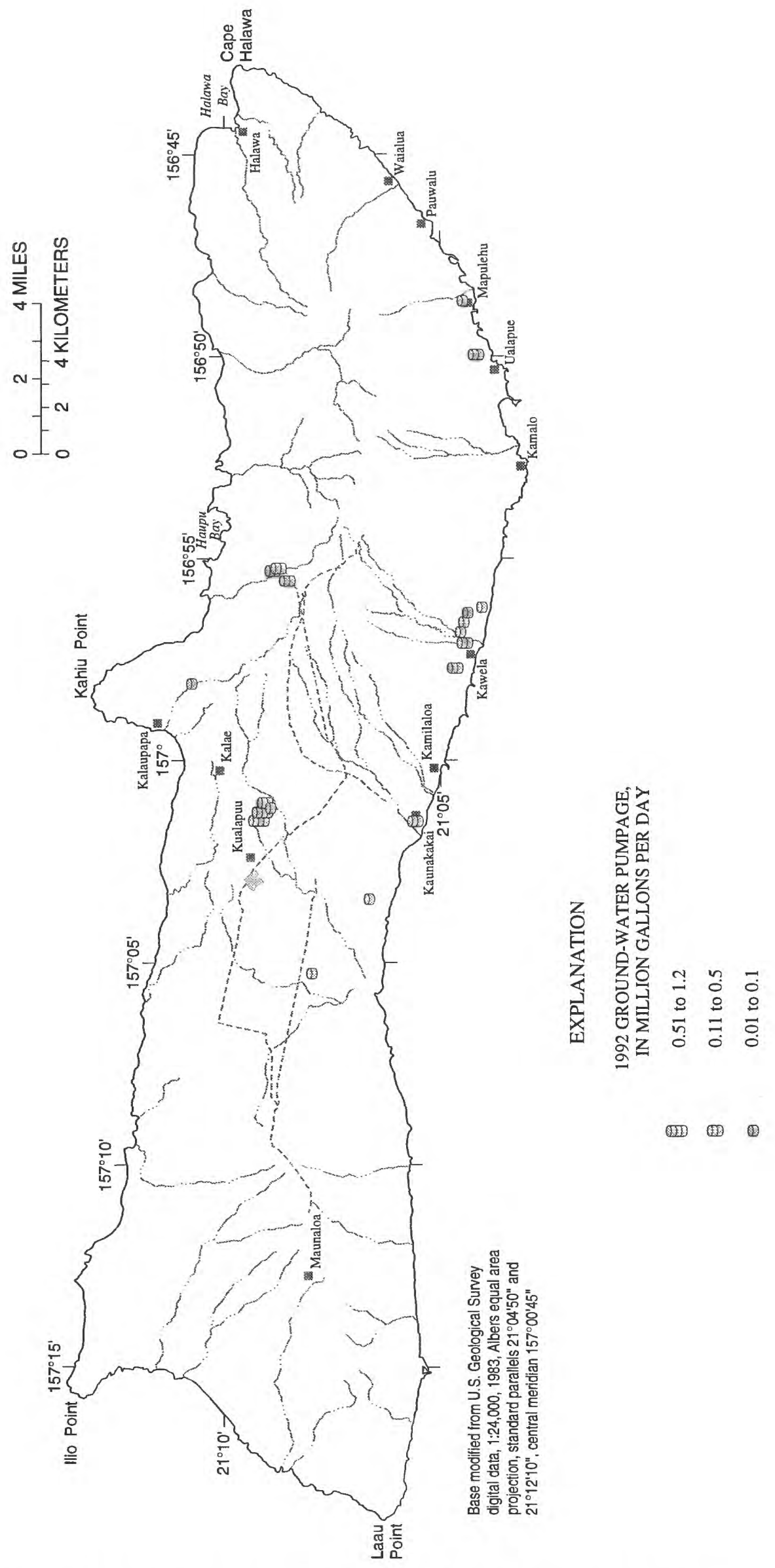




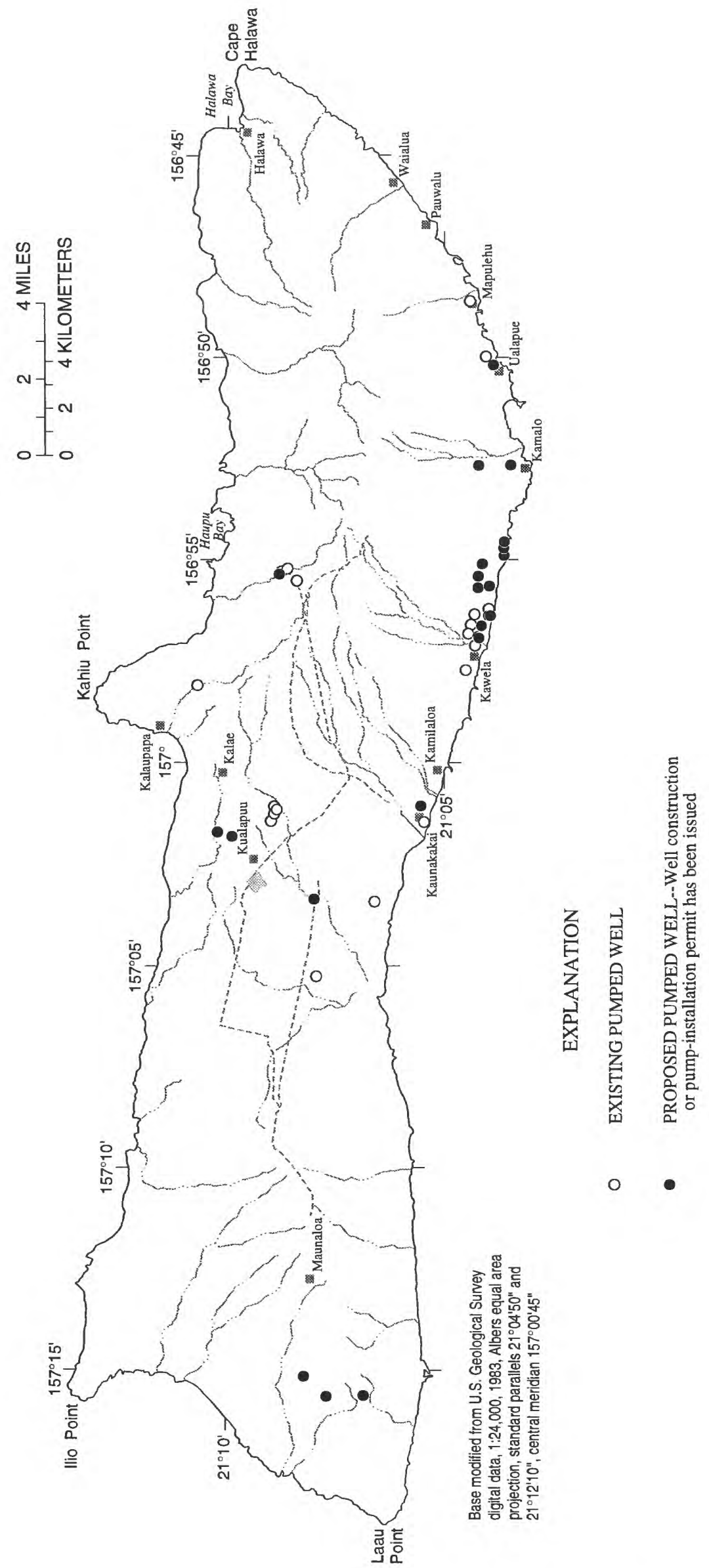

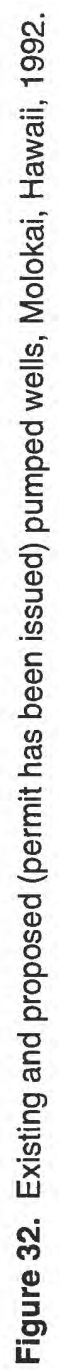




\begin{tabular}{|c|c|c|c|c|}
\hline \multirow[b]{2}{*}{$\begin{array}{l}\text { Type of data } \\
\text { collected }\end{array}$} & \multirow[b]{2}{*}{ Well type } & \multirow[b]{2}{*}{$\begin{array}{c}1992 \\
\text { PROGRAM }\end{array}$} & \multicolumn{2}{|c|}{$\begin{array}{c}\text { ADDITIONAL } \\
\text { LOCATIONS NEEDED }\end{array}$} \\
\hline & & & Candidate & $\begin{array}{c}\text { Total } \\
\text { number needed }\end{array}$ \\
\hline \multicolumn{5}{|c|}{ Kualapuu } \\
\hline Water level & Observation & $\begin{array}{l}0601-01 \\
0700-01\end{array}$ & & 11 \\
\hline \multirow[t]{3}{*}{ Chloride } & Observation & $0601-01$ & $0700-01$ & 11 \\
\hline & $\begin{array}{l}\text { Deep } \\
\text { monitoring }\end{array}$ & & & 4 \\
\hline & Pumped & $\begin{array}{l}0801-01 \\
0801-02 \\
0901-01\end{array}$ & 0801-03 & 1 \\
\hline \multicolumn{5}{|c|}{ Kawela-Mapulehu } \\
\hline Water level & Observation & $\begin{array}{l}0448-02 \\
0449-01^{a} \\
0457-01^{a}\end{array}$ & & 4 \\
\hline \multirow[t]{3}{*}{ Chloride } & Observation & $0448-02$ & & 3 \\
\hline & $\begin{array}{l}\text { Deep } \\
\text { monitoring }\end{array}$ & & & 2 \\
\hline & Pumped & $\begin{array}{l}0457-01 \\
0449-01\end{array}$ & $\begin{array}{l}0456-04 \\
0456-06 \\
0456-08 \\
0456-09 \\
0457-04\end{array}$ & 5 \\
\hline \multicolumn{5}{|c|}{ Waikolu Valley } \\
\hline Water level & Observation & & & 0 \\
\hline
\end{tabular}

${ }^{a}$ Pumped well

Figure 33. Water-management network wells and number of additional locations needed, Molokai, Hawaii, 1992.

and Ualapue, were classified as water-management wells for the collection of chloride-concentration data (fig. 33). The Kawela Plantation pumped wells (0456-04, -06, -08, -09, and 0457-04) were identified as candidate water-management wells to monitor the chloride concentration of water pumped from the basal-water body inland of the DWS Maui-type well near Kawela (fig. 33). No observation wells exist near Kawela. In addition, no deep monitoring wells exist to monitor the vertical movement of the zone of transition between freshwater and saltwater. Locations where deep monitoring wells and observation wells open to the producing zone are needed for chloride-concentration data are shown in figure 35 . The observation well locations are the same as those needed for water-level data.
Waikolu Valley.--The Waikolu Valley area is located in the northern part of the East Molokai Volcano. In this area, dike-impounded water is withdrawn from three pumped wells owned by the Department of Agriculture. In 1992, the combined average pumpage from these wells was $0.9 \mathrm{Mgal} / \mathrm{d}$ (fig. 31). The water from these wells is pumped into the Molokai Irrigation System and used to irrigate agricultural fields in central Molokai. The average flow through the Molokai Irrigation System is $4.2 \mathrm{Mgal} / \mathrm{d}$ at the west portal of the tunnel (Matsuoka and others, 1993). The water in the tunnel comes from three stream diversions on Waikolu Stream, three pumped wells, and groundwater discharge along the length of the tunnel. Base flow in Waikolu Stream is supported by the discharge 


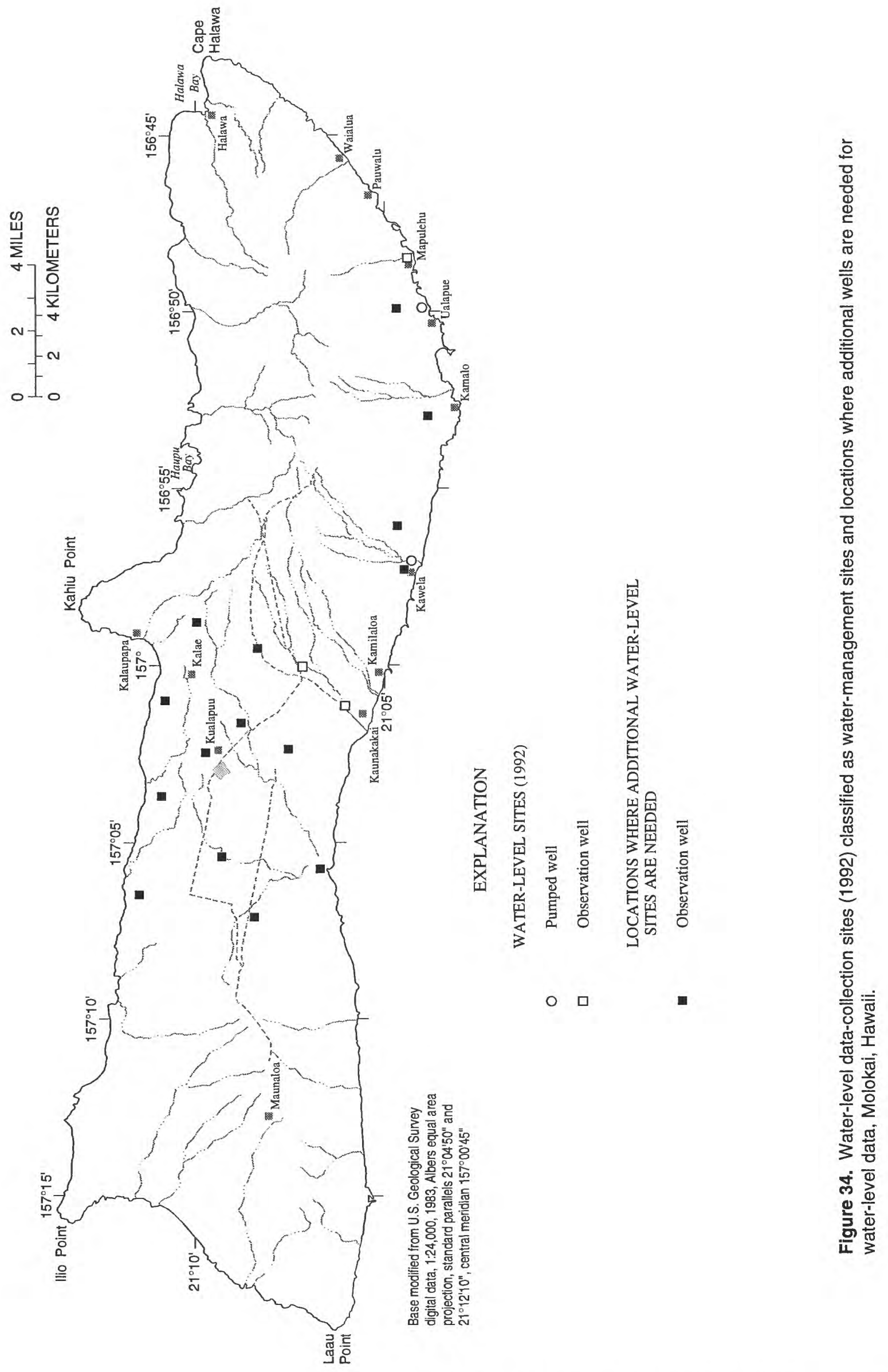




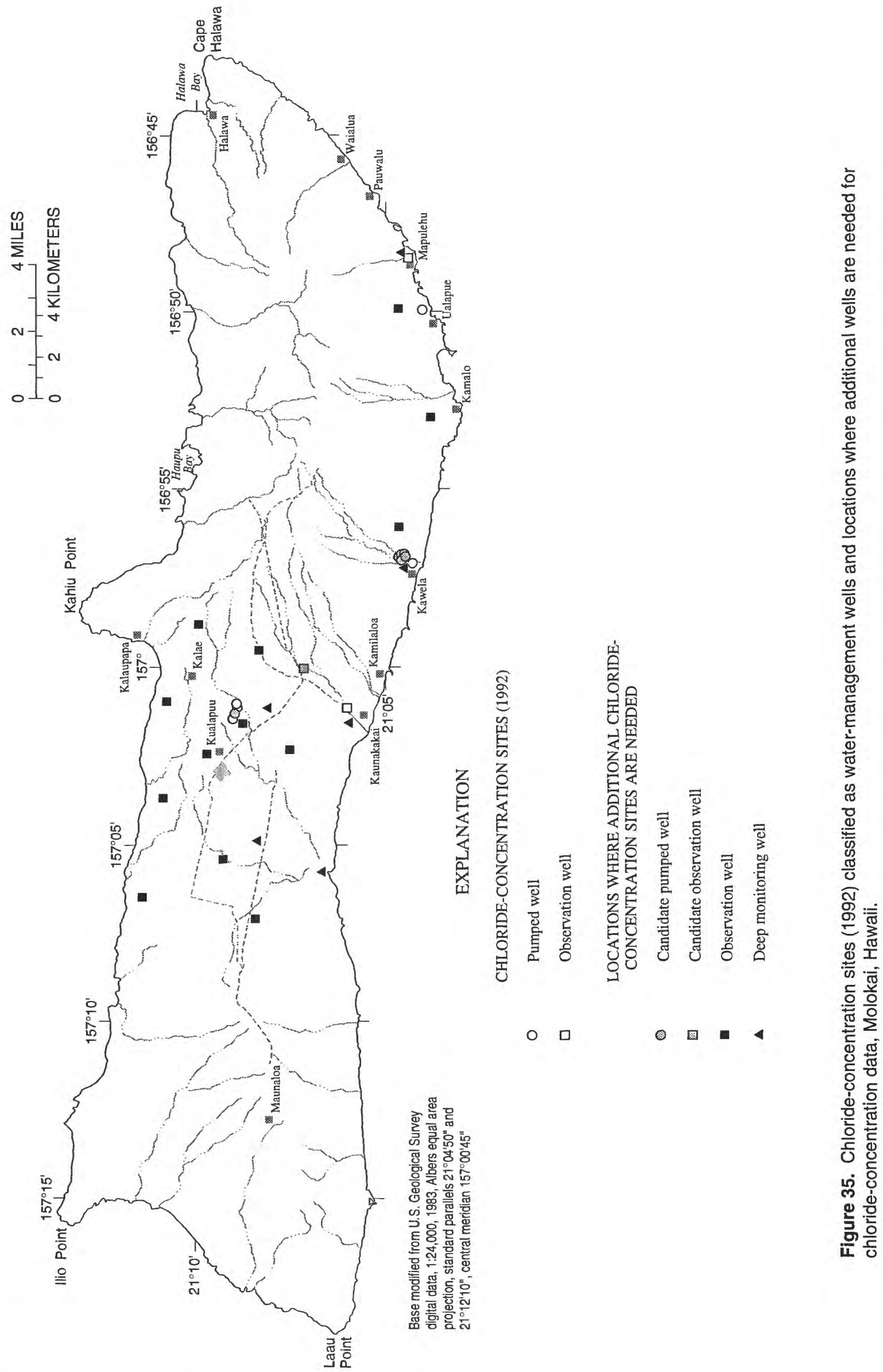


of dike-impounded water to the stream channel. The USGS currently operates two continuous streamflow gages on Waikolu Stream. A water-management network is needed in Waikolu Stream valley to observe the effect of pumping dike-impounded water on groundwater levels and on ground-water discharge to Waikolu Stream.

Additional information on the hydrologic interaction between ground water and surface water is needed to determine locations where observation wells are needed for water-level data. A series of streamflow measurements (seepage runs) made along the stream during baseflow conditions would provide information on where the stream gains and loses water. This information could be used to estimate the spatial and vertical distribution of observation wells needed to monitor hydraulic gradients and the effect of pumping dikeimpounded water on ground-water levels and groundwater discharge to Waikolu Stream. It should be noted that there are several unused observation wells (pilot holes) in Wailoku Valley that could be field checked to determine their suitability for measuring water levels.

\section{Hawaii}

The island of Hawaii consists of five coalesced shield volcanoes: Kilauea, Mauna Loa, Mauna Kea, Hualalai, and Kohala (fig. 36). The oldest is Kohala, and the youngest is Kilauea. Except for the northeastern sides of Kohala and Mauna Kea, little erosion has taken place on these volcanoes. The few perennial streams on the island indicate the highly permeable nature of the surface rocks.

In 1992, the USGS ground-water data-collection program consisted of 5 observation wells and 39 pumped wells (table 6). Water levels were measured at about 12-week intervals in all five observation wells, and three of the pumped wells (fig. 37). In addition, continuous water levels were recorded in the Kahaluu Maui-type well (3557-05). Water-quality samples were collected at about 12-week intervals from one of the observation wells and 32 of the pumped wells (fig. 38). Occasionally some of the pumped wells were not operating during each site visit. As result, the record of water-quality data is incomplete for 27 of the 39 pumped wells in the program (table 6). Well depth is known for all of the wells except for the Waikane Mauitype well (7652-01).
Ground-water pumpage on the island of Hawaii averaged about $44 \mathrm{Mgal} / \mathrm{d}$ in 1992 on the basis of data reported to the CWRM. Two-thirds of the water pumped, $29 \mathrm{Mgal} / \mathrm{d}$, was used for municipal or domestic purposes. The remainder, about $15 \mathrm{Mgal} / \mathrm{d}$, was used for agriculture, landscaping, and golf courses. Owing to a tremendous surge in resort and related developments, the demand for ground water is projected to increase by about $100 \mathrm{Mgal} / \mathrm{d}$ by the year 2010 (State of Hawaii, Commission on Water Resource Management, 1992e). The primary growth areas are along the western shore (Kona coast) of the island, between Honaunau Bay in the south and Kawaihae Bay in the north. Water-supply systems in these areas are presently stressed to near limits of supply capacity. Recently discovered high-level water in the western part of the Hualalai Volcano, and basal water in the northern part of the Kohala Volcano are potential sources for ground-water development (Bauer, 1993).

The distribution and magnitude of pumpage (fig. 39) and distribution of proposed pumped wells (fig. 40) indicates a need for water-management networks in the vicinity of existing well fields in the area between Honaunau and Kawaihae Bay. In addition, water-management networks are needed in the northern part of the Kohala Volcano between the town of Hawi and Pololu Stream valley because of plans to develop $20 \mathrm{Mgal} / \mathrm{d}$ in this area. Wells needed to meet the objectives of a water-management networks in these areas are described below.

North Kohala.--The North Kohala area is located in the northern part of the Kohala Volcano between the town of Hawi and Pololu Stream valley. The primary source of ground water in the North Kohala area is a basal-water body with water levels that range from $2 \mathrm{ft}$ to about $12 \mathrm{ft}$ above sea level. Presently, the DWS operates four water systems in the North Kohala area with a combined demand of $0.5 \mathrm{Mgal} / \mathrm{d}$. In 1992, the DWS pumped an average of $0.4 \mathrm{Mgal} / \mathrm{d}$ from well 7449-02 near Hawi; the remainder of water was derived from four water development tunnels. Private purveyors are estimated to pump less than $1.0 \mathrm{Mgal} / \mathrm{d}$ in the North Kohala area.

Large-scale developments are planned for the dry southwestern side of the Kohala Volcano. To help supply the future demand for water, the Hawaii County Department of Water Supply (DWS) plans to develop at least $20 \mathrm{Mgal} / \mathrm{d}$ of basal water from the northern part of 

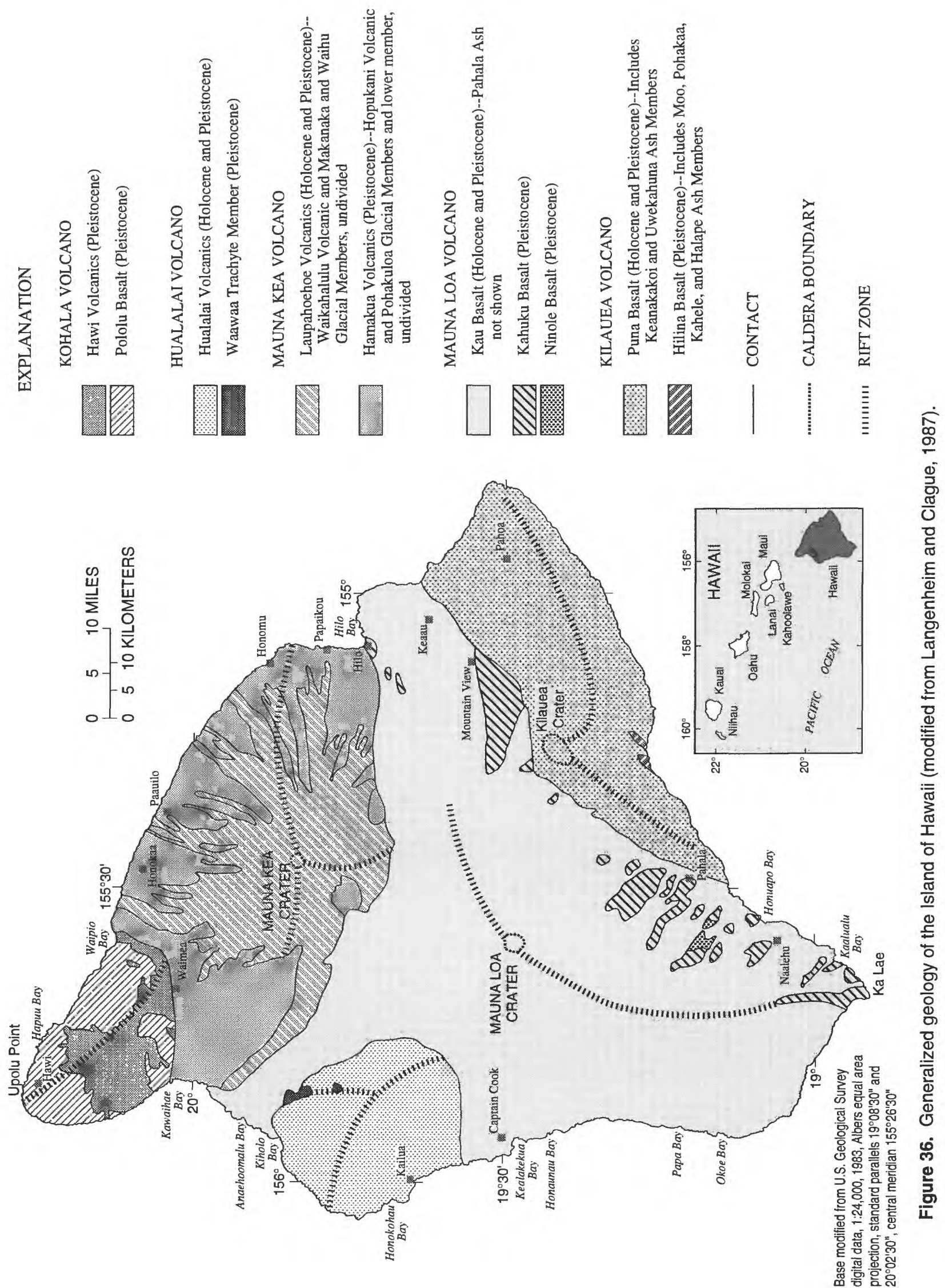


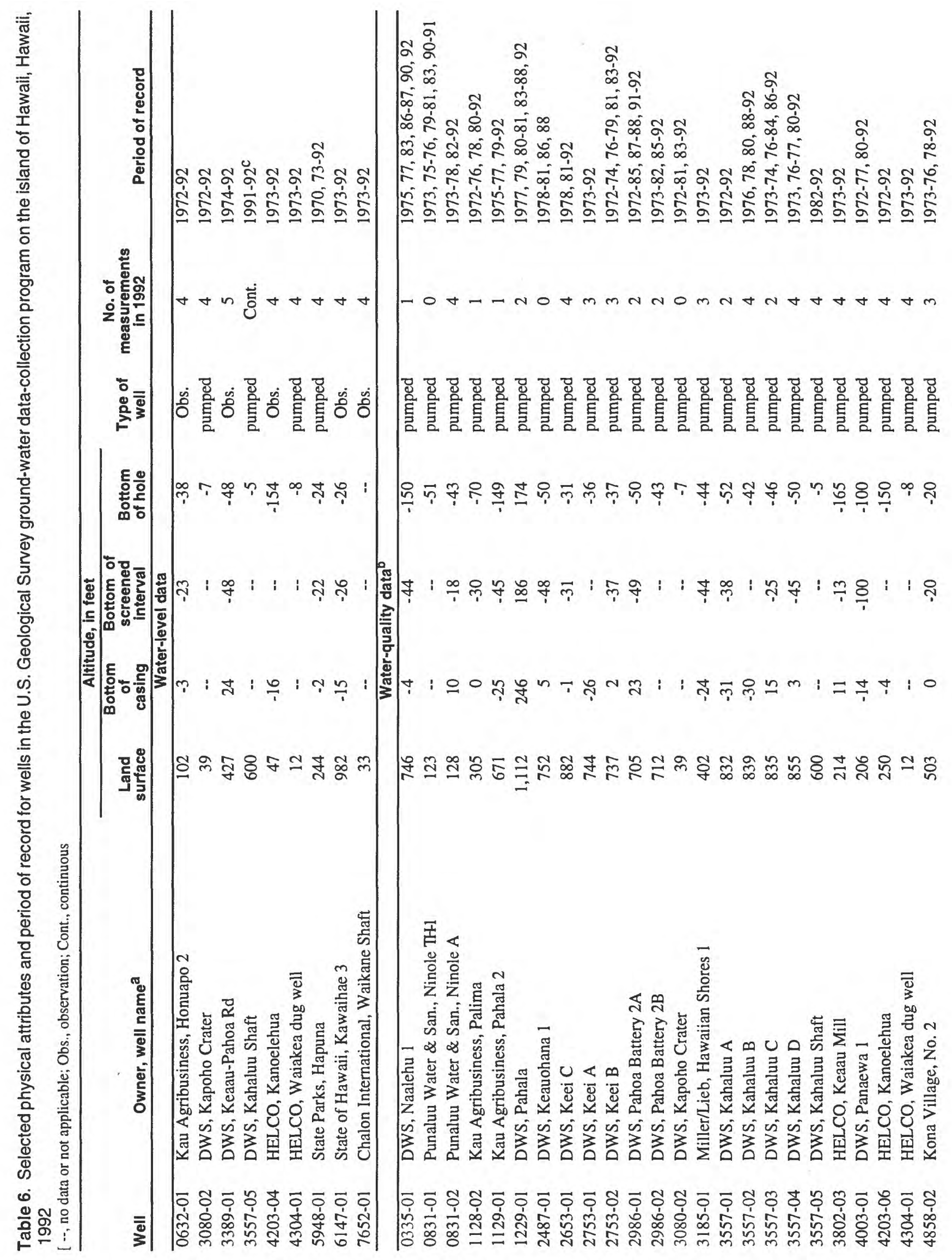




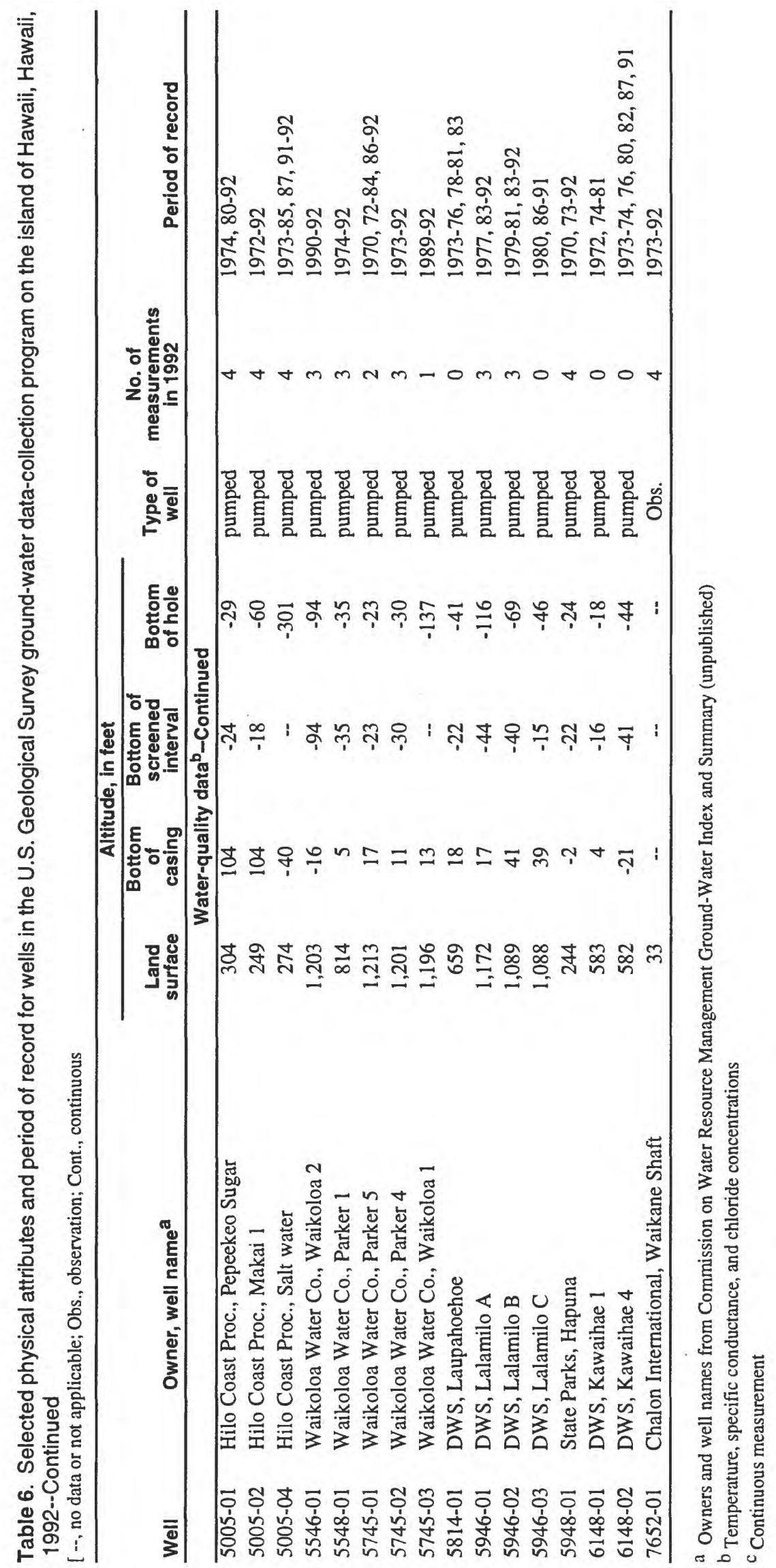




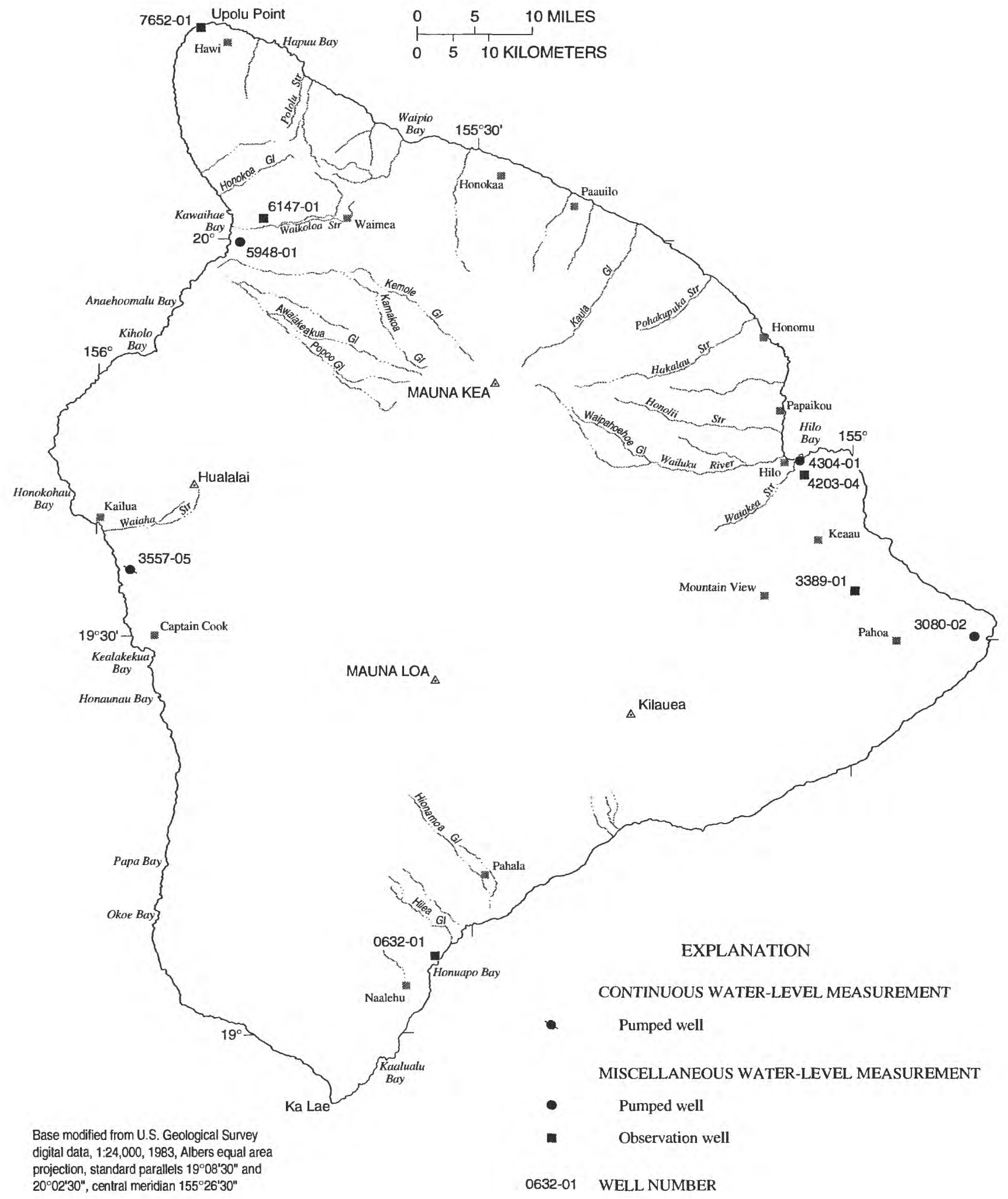

Figure 37. Wells where water-level data were collected as part of the U.S. Geological Survey ground-water data-collection program, island of Hawaii, Hawaii, 1992. 


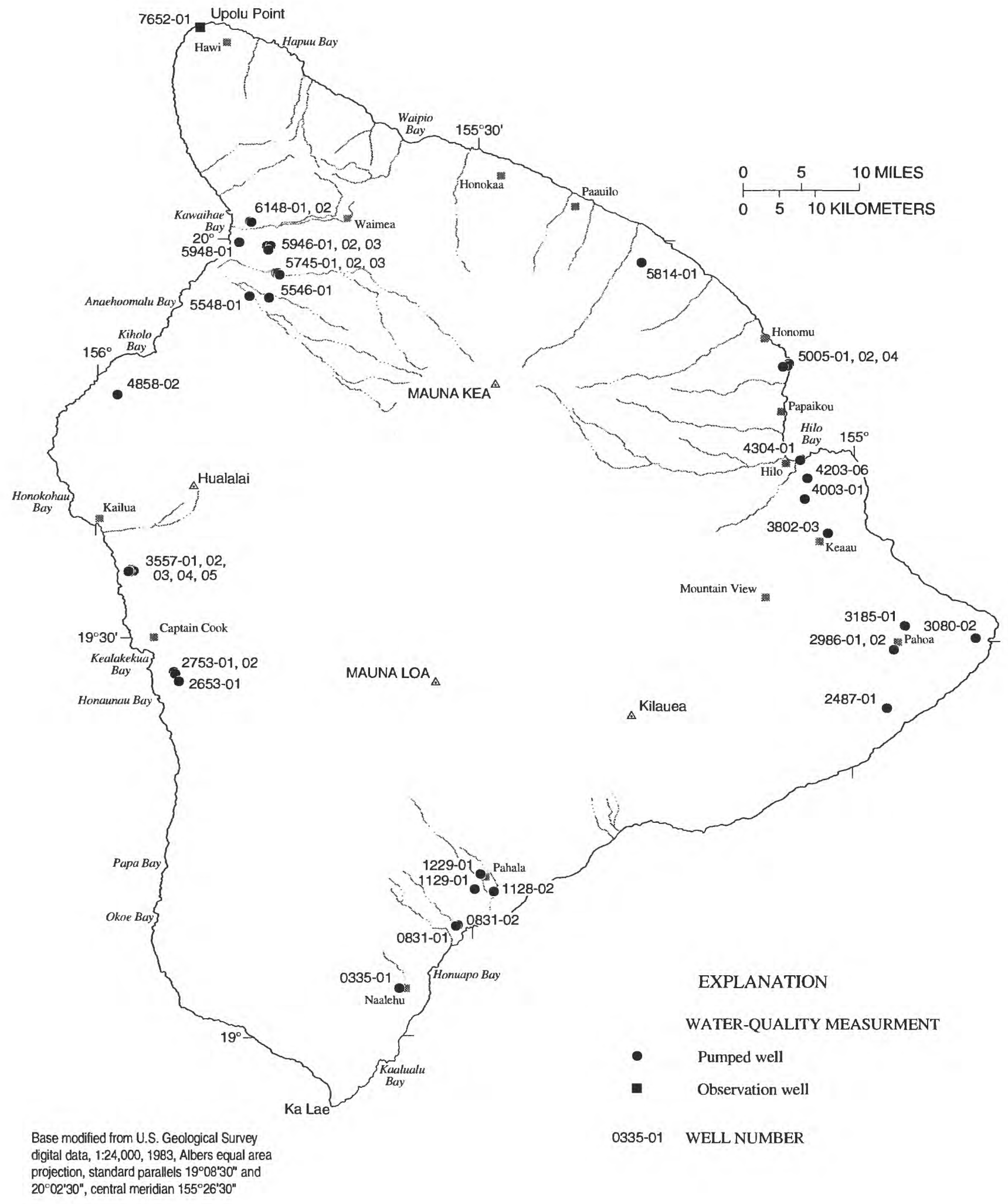

Figure 38. Wells where water-quality data were collected as part of the U.S. Geological Survey ground-water data-collection program, island of Hawaii, Hawaii, 1992. 


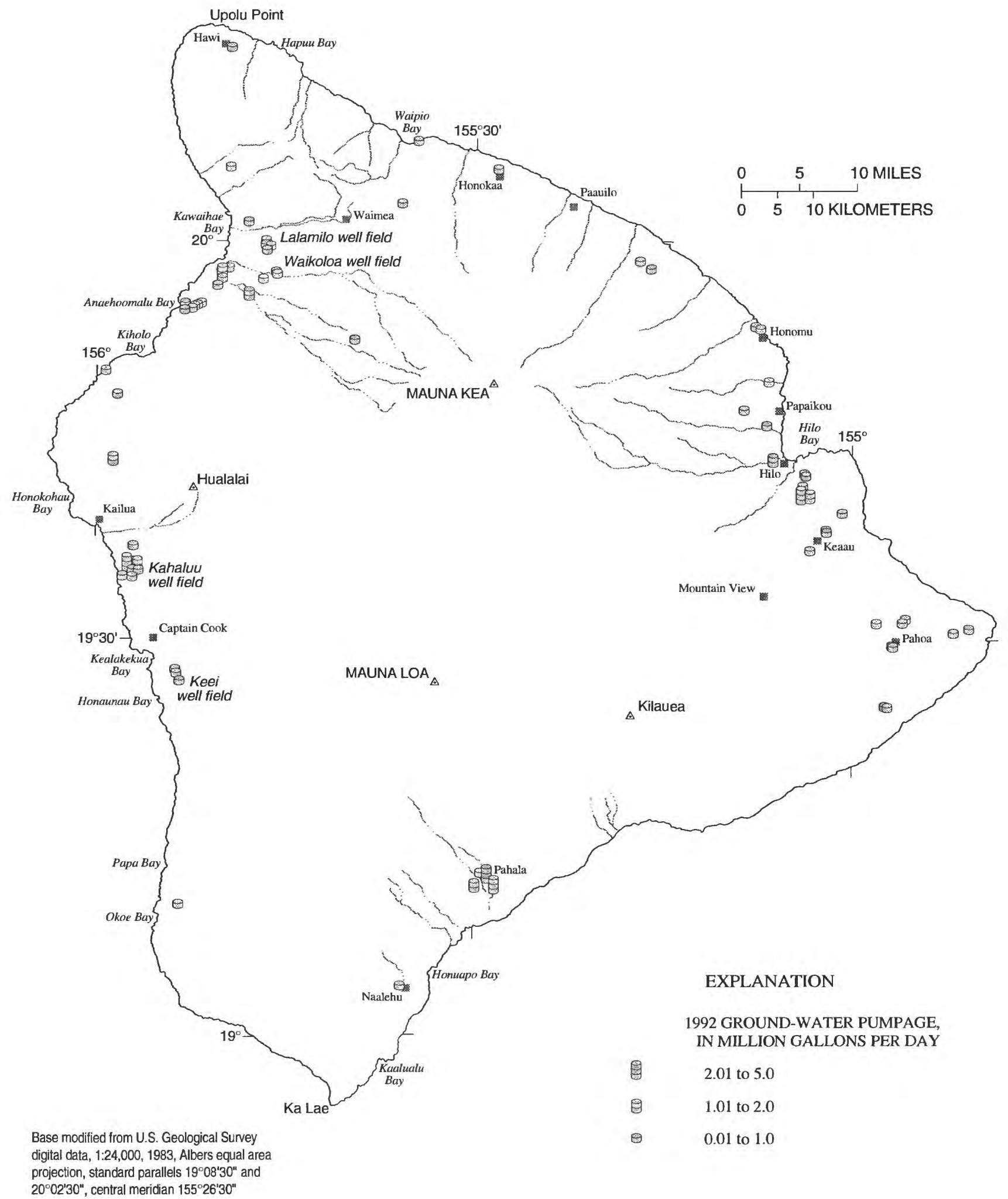

Figure 39. Distribution and magnitude of ground-water pumpage, island of Hawaii, Hawaii, 1992. 


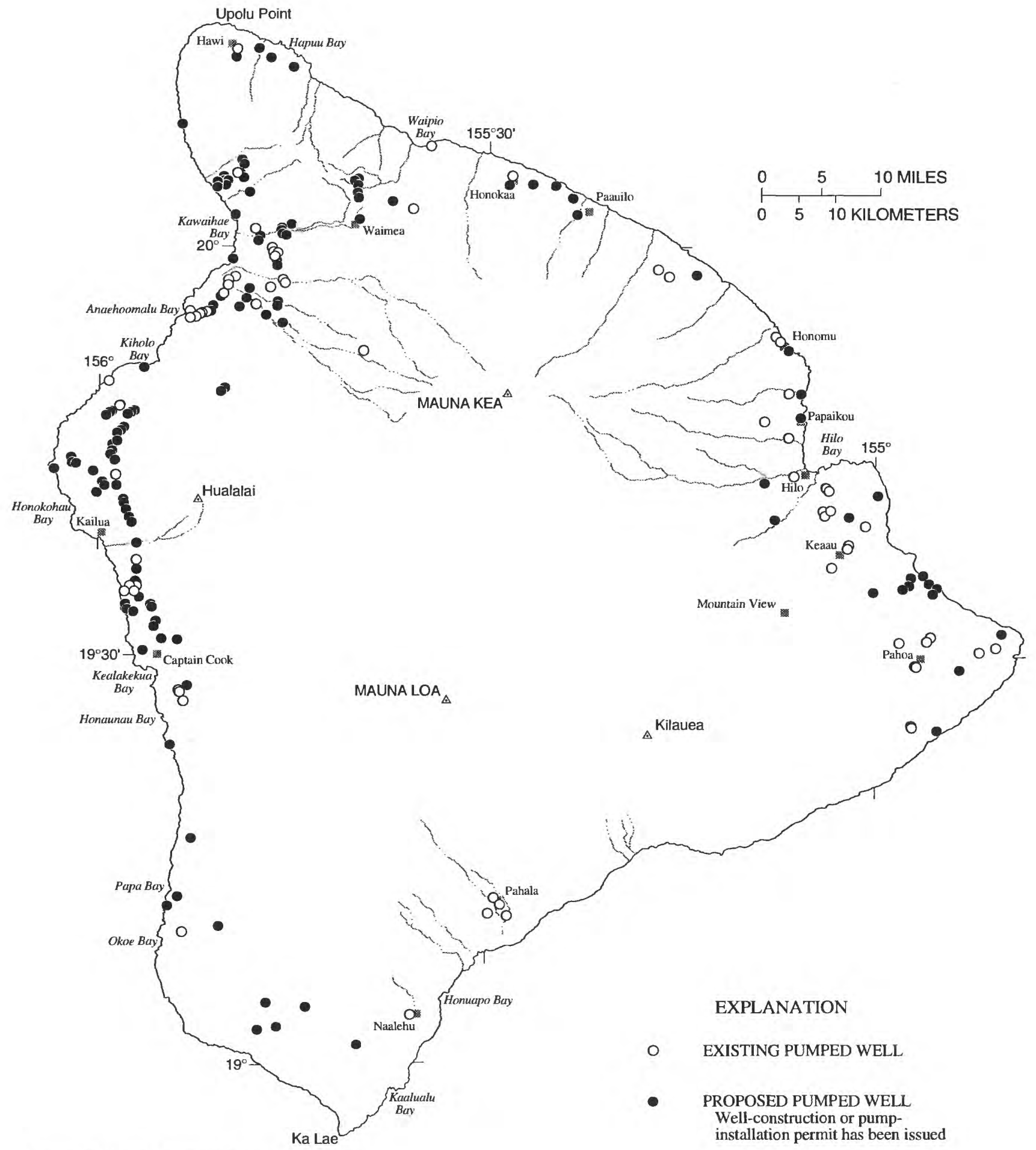

Base modified from U.S. Geological Survey

digital data, 1:24,000, 1983, Albers equal area

projection, standard parallels $19^{\circ} 08^{\prime \prime} 30^{\prime \prime}$ and

$20^{\circ} 02^{\prime} 30^{\prime \prime}$, central meridian $155^{\circ} 26^{\prime} 30^{\prime \prime}$

Figure 40. Existing and proposed (permit has been issued) pumped wells, island of Hawaii, Hawaii, 1992. 
the volcano and distribute it along the southwestern side of the volcano. In 1989, observation wells were drilled at eight locations between Hawi and Pololu Stream valley as part of a cooperative USGS/DWS ground-water availability study. At two of these locations, a deep monitoring well was drilled through the upper part of the zone of transition between freshwater and saltwater. Results from these wells indicate that the freshwater part of the basal-water body is about $100 \mathrm{ft}$ thick near Hawi and about $350 \mathrm{ft}$ thick near Hapuu Bay. Waterlevel and water-quality data were collected by the USGS in only one observation well in the North Kohala area in 1992. This well was classified as a water-management well for the collection of water-level data (figs. 41 and 42). The USGS/DWS observation wells drilled in 1989 were identified as candidate wells for collecting water-level and chloride-concentration data (figs. 41, 42, and 43).

South Kohala.--The South Kohala area is located in the southern part of the Kohala Volcano between Kawaihae Bay in the north and Anaehoomalu Bay in the south. The west coast of South Kohala is a popular visitor destination owing to its sunny and dry climate and several large resort complexes. The primary source of ground water in the South Kohala area is a basal-water body with water levels that range from less than $2 \mathrm{ft}$ to about $16 \mathrm{ft}$ above mean sea level. Ground-water pumpage in the area was about $11.5 \mathrm{Mgal} / \mathrm{d}$ in 1992 . Nearly one-half of this water was brackish and used for golf courses and landscaping. Brackish ground-water withdrawals are concentrated between Kawaihae and Anaehoomalu Bay at a distance of less than $3 \mathrm{mi}$ from shore (fig. 39). Potable ground-water withdrawals are located inland of the brackish water wells at a distance of 3 to 7 mi from shore (fig. 39). These withdrawals are concentrated in the Lalamilo and Waikoloa well fields.

Twenty-three additional pumped wells are proposed along the coast of the South Kohala area (fig. 40). The demand for potable water in this area is projected to increase by more than $30 \mathrm{Mgal} / \mathrm{d}$ by the year 2010 (State of Hawaii, Commission on Water Resource Management, 1992e).

Water-level measurements were made by the USGS in only one observation well in the South Kohala area in 1992 (fig. 37 and table 6). This well was classified as a water-management well for the collection of water-level data (fig. 41). Locations where additional observation wells are needed for water-level data are shown in figure 42 .
Water-quality samples were collected by the USGS from 11 pumped wells in 1992 (fig. 38 and table 6 ). All of these wells were classified as water-management wells (fig. 41) to monitor the chloride concentration of water pumped. Locations where observation wells open to the producing zone are needed for chloride-concentration data are shown in figure 43 . These locations are the same as those needed for water-level data. No deep monitoring wells exist to monitor the vertical movement of the zone of transition between freshwater and saltwater. As a result, a deep monitoring well is needed near the Lalamilo well field for chloride-concentration data (fig. 43).

Kona.--The Kona area is located along the western slopes of the Hualalai and Mauna Loa Volcanoes between Honaunau Bay in the south and Kiholo Bay in the north. The Kona area is undergoing rapid economic growth primarily due to an expanding tourism industry. This growth is concentrated from Kailua village south toward Kealakekua Bay. Despite the dominance of the tourism industry in the Kona area's economy, diversified agriculture continues to develop as well as commercial activities in and around Kailua Village.

In 1992 ground-water pumpage was about 11 $\mathrm{Mgal} / \mathrm{d}$ in the Kona area. The DWS pumped more than 90 percent of this water; about $8.4 \mathrm{Mgal} / \mathrm{d}$ from the Kahaluu well field, and $0.9 \mathrm{Mgal} / \mathrm{d}$ from the Keei well field (fig. 39). Private purveyors are estimated to pump less than $1 \mathrm{Mgal} / \mathrm{d}$. The primary source of ground water in the area is a thin basal-water body with heads that range from less than $2 \mathrm{ft}$ to a maximum of $7 \mathrm{ft}$. The demand for potable water in the area is projected to increase by more than $22 \mathrm{Mgal} / \mathrm{d}$ by the year 2010 (State of Hawaii, Commission on Water Resource Management, 1992e). To help alleviate this demand for water, 45 additional pumped wells are proposed in the area (fig. 40).

A new source of potable ground water was recently discovered in the area (Bauer, 1993). This vertically extensive ground-water body is defined by water-level data from 13 wells which were drilled along the 1,500 $\mathrm{ft}$ elevation contour between Kiholo Bay in the north and Kealakekua Bay in the south. Water levels in these wells range from 40 to $490 \mathrm{ft}$ above mean sea level, in contrast to less than $7 \mathrm{ft}$ in the basal-water body near the shore. Between Kiholo Bay and Kealakekua Bay, there are no observation wells in the USGS ground-water data-collection program. However, the CWRM cur- 


\begin{tabular}{|c|c|c|c|c|}
\hline \multirow[b]{2}{*}{$\begin{array}{l}\text { Type of data } \\
\text { collected }\end{array}$} & \multirow[b]{2}{*}{ Well type } & \multirow[b]{2}{*}{$\begin{array}{c}1992 \\
\text { PROGRAMS }\end{array}$} & \multicolumn{2}{|c|}{$\begin{array}{c}\text { ADDITIONAL } \\
\text { LOCATIONS NEEDED }\end{array}$} \\
\hline & & & Candidate & $\begin{array}{c}\text { Total } \\
\text { number needed }\end{array}$ \\
\hline \multicolumn{5}{|c|}{ North Kohala } \\
\hline Water level & Observation & $7652-01$ & $\begin{array}{ll}7445-01 & 7448-06 \\
7345-03 & 7449-03 \\
7347-03 & 7451-02 \\
7347-04 & 7549-03\end{array}$ & 8 \\
\hline \multirow[t]{3}{*}{ Chloride } & Observation & $7652-01$ & $\begin{array}{ll}7345-03 & 7448-06 \\
7347-03 & 7449-03 \\
7347-04 & 7451-02\end{array}$ & 6 \\
\hline & Deep monitoring & & $\begin{array}{l}7445-01 \\
7549-03\end{array}$ & 2 \\
\hline & Pumped & & & 0 \\
\hline \multicolumn{5}{|c|}{ South Kohala } \\
\hline Water level & Observation & $\begin{array}{l}6147-01 \\
5948-01^{a}\end{array}$ & & 8 \\
\hline \multirow[t]{3}{*}{ Chloride } & Observation & & $6147-01$ & 8 \\
\hline & Deep monitoring & & & 1 \\
\hline & Pumped & $\begin{array}{ll}5546-01 & 5946-02 \\
5548-01 & 5946-03 \\
5745-01 & 5948-01 \\
5745-02 & 6148-01 \\
5745-03 & 6148-02 \\
5946-01 & \end{array}$ & & \\
\hline \multicolumn{5}{|c|}{ North and South Kona } \\
\hline Water level & Observation & $3557-05^{a}$ & $\begin{array}{ll}3056-01 & 3957-02 \\
3155-01 & 4158-02 \\
3255-01 & 4160-02 \\
3255-02 & 4258-02 \\
3457-02 & 4360-01 \\
3456-01 & 4558-02 \\
3657-02 & 4559-01\end{array}$ & 14 \\
\hline \multirow[t]{3}{*}{ Chloride } & Observation & & $\begin{array}{ll}3056-01 & 4160-02 \\
3457-02 & 4360-01 \\
3456-01 & 4559-01 \\
3657-02 & \end{array}$ & 7 \\
\hline & Deep monitoring & & & 1 \\
\hline & Pumped & $\begin{array}{ll}2653-01 & 3557-03 \\
2753-01 & 3557-04 \\
2753-02 & 3557-05 \\
3557-01 & 4858-02 \\
3557-02 & \end{array}$ & & 0 \\
\hline
\end{tabular}

a Pumped well

Figure 41. Water-management network wells and number of additional locations needed, island of Hawaii, Hawaii, 1992. 


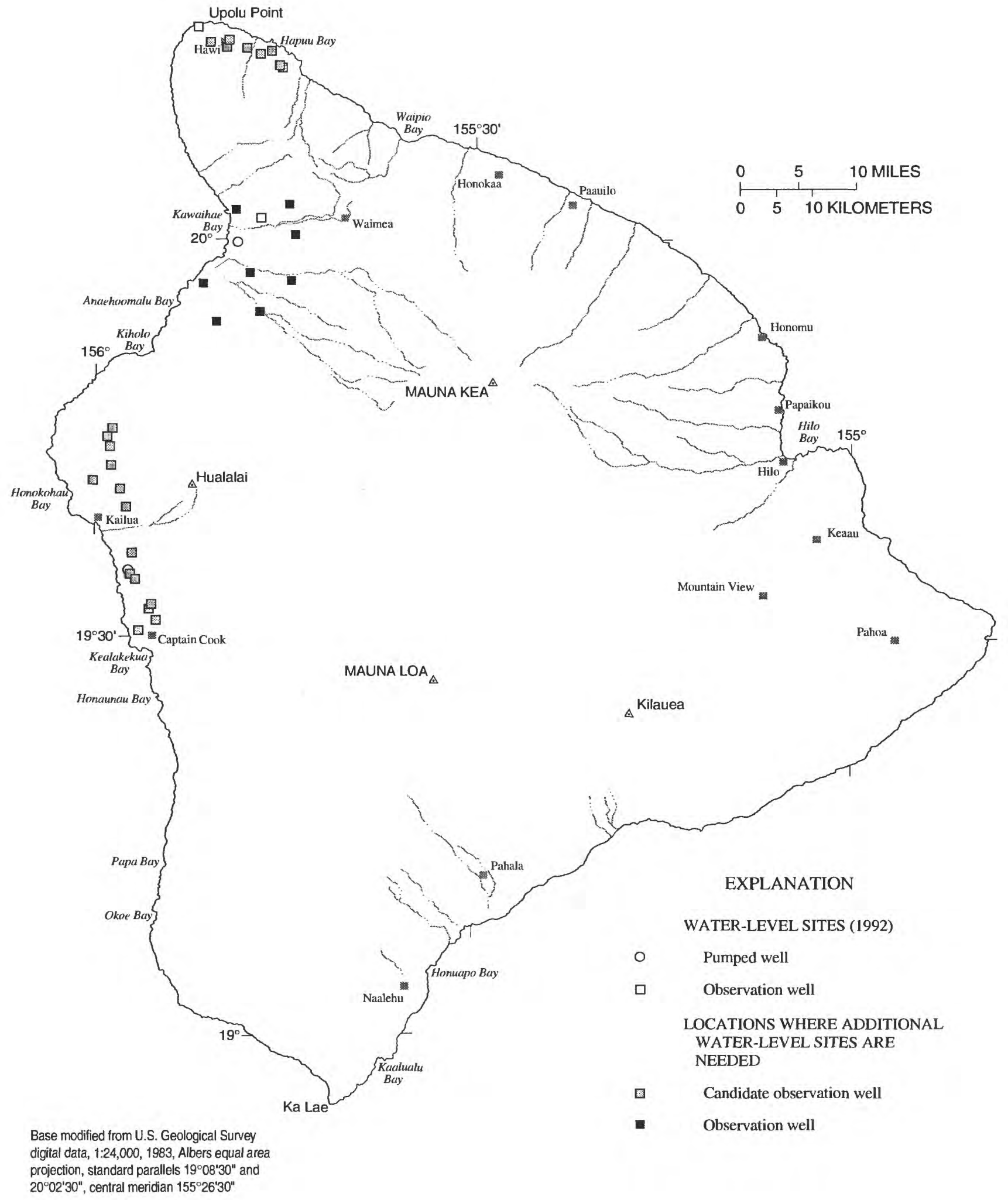

Figure 42. Water-level data-collection sites (1992) classified as water-management wells and locations where additional wells are needed for water-level data, island of Hawaii, Hawaii. 


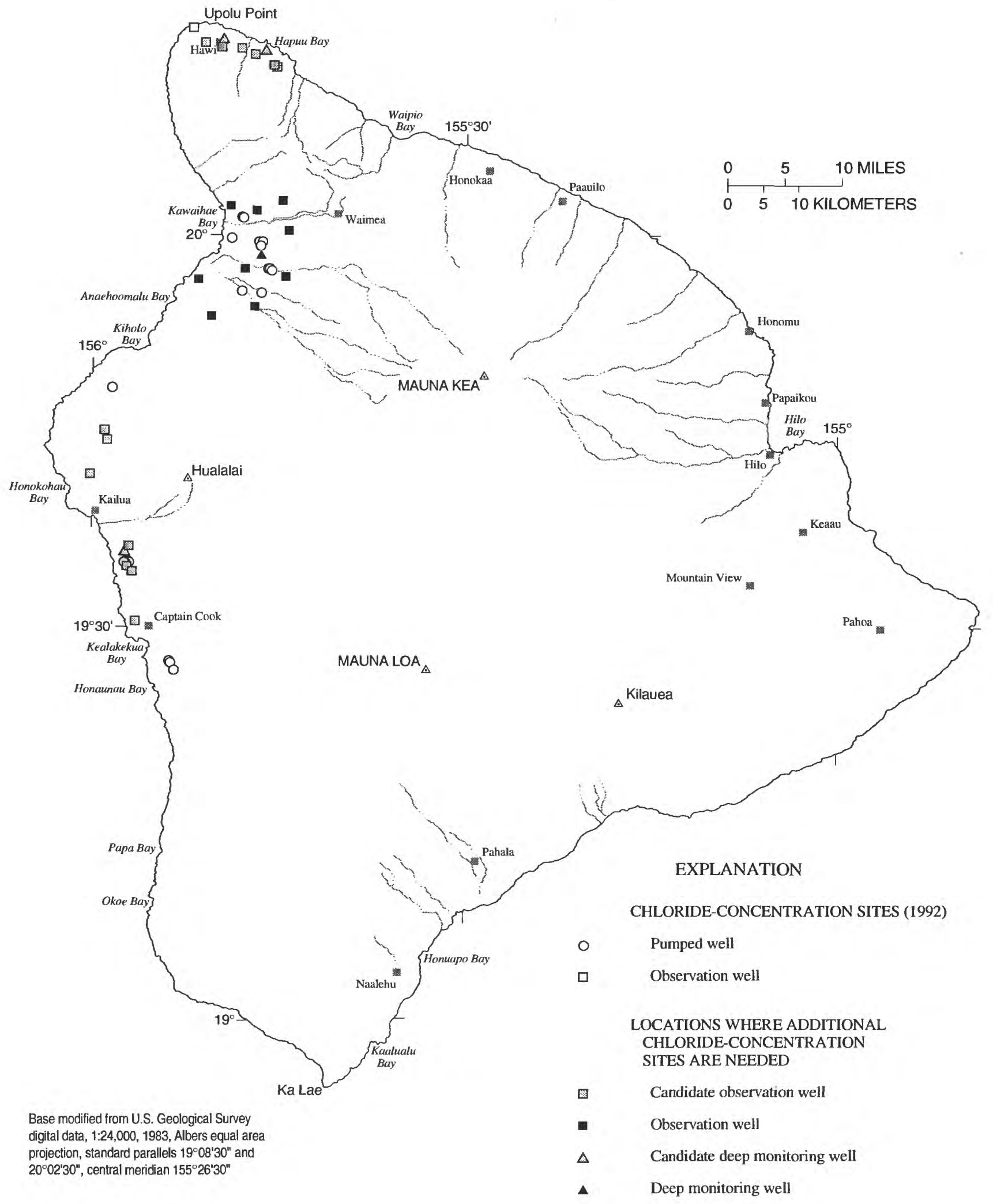

Figure 43. Chloride-concentration data-collection sites (1992) classified as water-management wells and locations where additional wells are needed for chloride-concentration data, island of Hawaii, Hawaii. 
rently collects water-level data from 36 wells in this area. A water-management network consisting of 14 candidate observation wells is listed in figure 41 and shown in figure 42 . These candidate wells represent a sub-set of the wells currently being monitored by the CWRM, plus four additional locations near the Kahaluu well field. The additional locations near the Kahaluu well field are needed to periodically determine the status of ground-water storage in the area (fig. 42).

Water-quality samples were collected by the USGS from eight pumped wells in the Kona area in 1992 (fig. 38 and table 6). All of these wells, which are needed to monitor the chloride concentration of water pumped from the Kahaluu and Keei well fields, were classified as water-management wells (fig. 41). Locations where observation wells open to the producing zone are needed for chloride-concentration data are shown in figure 43 . These candidate observation well locations are the same as those needed for water-level data, excluding for the wells located in the vertically extensive ground-water body. No deep monitoring wells exist to monitor the vertical movement of the zone of transition between freshwater and saltwater. A deep monitoring well is needed near the Kahaluu well field (fig. 43), because the chloride concentration of pumped water from the well field often exceeds $250 \mathrm{mg} / \mathrm{L}$.

\section{DATA COLLECTION, STORAGE, AND REVIEW}

The collection of water-level and water-quality (temperature, specific conductance, and chloride-concentration) data is fundamental to ground-water studies in Hawaii. The ground-water data collection procedures used by the Hawaii District of the USGS are described in the National Handbook of Recommended Methods for Water-Data Acquisition (U.S. Geological Survey, Office of Water Data Coordination, 1980). The use of a set of recommended methods for measuring, sampling, and analyzing water assures greater comparability, compatibility, and usability of water data.

Factors that need to be considered in the selection of wells for a data-collection program are location, accessibility, use, physical condition, and construction. An existing well can provide a convenient data-collection site at low cost. A well that is pumped occasionally is generally more suitable than one that has been abandoned. Abandoned or unused wells are commonly in poor condition because of damaged or leaky casing, corroded pumping equipment, or rotting wooden structures near or around the wells, which make the wells difficult to measure and safety hazards. A reliable and detailed description and a test of the effectiveness of a well to provide accurate water levels are needed of any well before it can be used to obtain reliable hydrologic information.

Wells drilled especially for observation purposes are desirable because all pertinent details on lithology, well construction, depth and other features of the well may be accurately determined and the site selected to fill recognized data needs. Ideally, observation wells should be constructed where possible; however, often it is not economically feasible to construct an observation well. As a result, most ground-water data-collection sites are used for water supply. Water-level and waterquality data collected from pumped wells can be useful if adequate information is available on their operation prior to measurement. To insure the collection of representative samples, field measurements of temperature and specific conductance are needed to evaluate whether a sample is representative of water in the aquifer. For water-level measurements, it is desirable for pumping from the well to have stopped long enough for the water levels to stabilize.

For comparability, water-level measurements must be referenced to the same datum (elevation). Mean sea level is the datum used in Hawaii. The measuring point is referenced to the mean sea level datum and is the most convenient place to measure the water level in a well. The measuring point must be as permanent as possible, clearly defined, marked, and easily located. Frequently, the top of the casing is designated as the measuring point; because the top of the casing is seldom smooth and horizontal, a particular point should be designated and marked clearly with paint and, if permitted, the letters MP with an arrow. The reference point for water-level measurements is an arbitrary datum established by permanent marks set on or near the well. It is used to check the measuring point, and its greatest value is in re-establishing a measuring point if one is destroyed or changed.

Water-level and water-quality data collected from wells in the ground-water data-collection program are stored in well folders at the Hawaii District office in Honolulu. The water-quality data also are stored in the National Water Information System (NWIS). NWIS is 
operated and maintained on the computer facilities of the Hawaii District office in Honolulu. Water-level and water-quality data are published annually in a USGS Water-Data Report. The 1991 Water-Data Report contained data from 162 of the 216 wells in the program (Matsuoka and others, 1992).

A network data file needs to be established for each well in the program. The network data file needs to contain: (1) a station folder that contains basic information about each well (described below), (2) a waterlevel/water-quality folder that contains a compilation of data, (3) an original data folder that contains charts from graphic recorders and automatic digital recorder (ADR) tapes, and (4) time-series graphs of water-level and water-quality data. The station folder needs to contain a network review form (described below), well-construction information, location maps and sketches, photographs, a copy of a segment of the water-level/waterquality time series, and copies of all correspondence and other notes relating to the well and data obtained from it. All data need to be stored in NWIS or a similar computerized data base.

Network review is an ongoing process. All network wells need to be reviewed periodically to determine if the wells continue to fulfill their objectives. A network review form has been devised to describe the physical attributes of the well, measuring point, history of observation, and changes in use of the well and nearby wells (fig. 44). This form also summarizes the objective, changes in physical setting, alternate wells nearby, and recommendations and decisions for each well. Most of the data required by this form are selfexplanatory, but a few specific items need some additional comment.

The network objective (water-management or baseline) needs to be listed followed by pertinent remarks, qualifications, or secondary objectives. The history of observation needs to describe all known natural and human-induced causes of water-level or chloride concentration fluctuations that have occurred.

Distances to the nearest known pumped well needs to be noted, as well as known or estimated pumpage values. Conversely, if pumped wells are not in the immediate area, this fact needs to be noted. Recommendations can include changes in recording instrumentation, changes in frequency of measurements, or the discontinuance of the well from the network.

\section{SUMMARY}

The USGS ground-water data-collection program in Hawaii consisted of 188 wells distributed among the islands of Oahu, Kauai, Maui, Molokai, and Hawaii in 1992. Water-level and water-quality (temperature, specific conductance, and chloride concentration) data were collected from three types of wells: (1) observation wells, (2) deep monitoring wells that penetrate the zone of transition between freshwater and saltwater, (3) free-flowing wells and (4) pumped wells. As part of the evaluation of the data-collection program, records of each well in the program were examined to determine: (1) period of record of water-level and chloride-concentration data, (2) if there is duplication of record from an adjacent well, (3) if the well is measured by well owner or another agency, and (4) if the well depth, and interval of the well open to aquifer material is known.

The evaluation of the ground-water data-collection program began with identifying a set of objectives for the program. The objectives are to collect sufficient spatial and temporal data to:

1. Define seasonal and long-term changes in groundwater levels and chloride concentrations induced by human-made stresses such as pumpage.

2. Define seasonal and long-term variations in groundwater levels and chloride concentrations induced by natural stresses for different climatic, and hydrogeologic settings.

Wells needed to meet these objectives can be divided into two types of networks: (1) a water-management network to determine the response of groundwater flow systems to human-induced stresses, such as pumpage (table 1), and (2) a baseline network to determine the response of ground-water flow systems to natural stresses for different climatic and hydrogeologic settings. An analysis of the water-level and chlorideconcentration data collected from these networks will provide information on: (1) the extent of aquifers, (2) changes in ground-water storage, and (3) the degree of confinement by considering the effect of precipitation, tides, and barometric pressure on ground-water levels. In addition, the data will provide information for the calibration and verification of ground-water flow models, and the design and management of ground-water withdrawal and waste disposal systems.

To identify areas in need of water-management networks, maps showing the distribution and magnitude 


\section{NETWORK REVIEW FORM}

Well ID

Owner

Latitude

USGS station number

Observation well, yes

Deep observation well, yes

no no
Local name

Point of contact

Phone \#

Longitude

\section{GEOGRAPHIC SETTING}

Topography

Nearest stream

Nearest stream-gaging station

Nearest rain gage

Nearest pumped well

Nearest observation well

\section{WELL CONSTRUCTION INFORMATION}

Ground surface

Bottom of casing

Bottom perf. casing

Bottom of hole ft above MSL $\mathrm{ft}$ above MSL ft above MSL ft above MSL
Pumped well, yes

Pump capacity no gpm

\section{HISTORY OF OBSERVATIONS}

Objective

Type of record

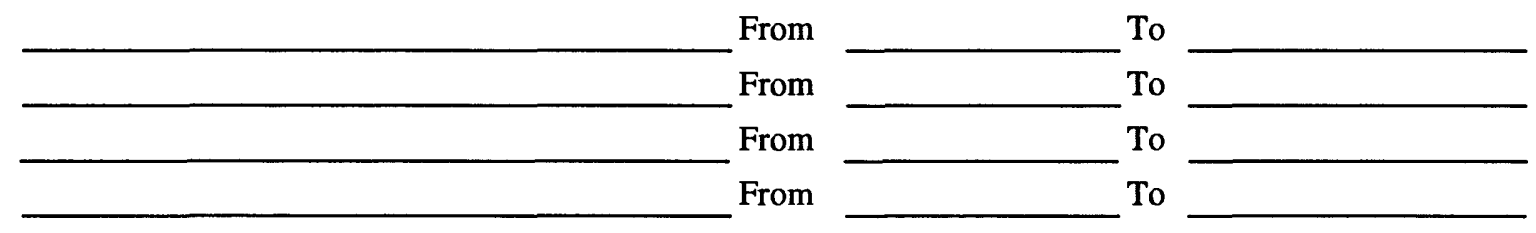

Max WL ft above MSL Date Min WL ft above MSL Date

Trends

$\mathrm{Max} \mathrm{Cl}$ $\mathrm{mg} / \mathrm{L}$

Date

$\operatorname{Min} \mathrm{Cl}$

$\mathrm{mg} / \mathrm{L} \quad$ Date

Trends

Figure 44. Example of a network review form. 


\section{MEASURING POINT DESCRIPTION}

MP \#1

MP \#2

MP \#3

Bench mark description ft above MSL Date ft above MSL Date ft above MSL Date

\section{CHANGES IN INSTRUMENTS, USE OF WELL,NEARBY WELLS, PHYSICAL SETTING, ETC.}

Date

Date

Date

Date

\section{ALTERNATE OBSERVATION WELLS}

\section{RECOMMENDATIONS}

Date

Date

Date

Date

Prepared by Date

Reviewed by Date

Figure 44. Example of a network review form--Continued. 
of pumpage, and the distribution of proposed pumped wells were made. The areas in need of water-management networks are listed below. Wells in the 1992 USGS ground-water data-collection program were then classified as either water-management or baseline network wells.

\begin{tabular}{|c|c|c|c|c|}
\hline$\overline{\text { Oahu }}$ & Kauai & Maui & Molokai & Hawaii \\
\hline Pearl Harbor & Lihue & Wailuku & Kualapuu & $\begin{array}{l}\text { North } \\
\text { Kohala }\end{array}$ \\
\hline Moanalua & Kapaa & Lahaina & $\begin{array}{l}\text { Kawela- } \\
\text { Mapulehu }\end{array}$ & $\begin{array}{l}\text { South } \\
\text { Kohala }\end{array}$ \\
\hline Honolulu & Koloa & $\begin{array}{l}\text { Central } \\
\text { Maui }\end{array}$ & Waikolu Valley & Kona \\
\hline \multicolumn{5}{|l|}{ Ewa } \\
\hline \multicolumn{5}{|l|}{ Waialua } \\
\hline \multicolumn{5}{|l|}{ Kahuku } \\
\hline Koolau & & & & \\
\hline
\end{tabular}

Because the distribution of wells in the 1992 USGS ground-water data-collection program is not sufficient to meet the objectives of a water-management network, locations where additional wells are needed for water-level and chloride-concentration data are identified. A priority listing of the locations where additional wells are needed, and a field inventory of existing observation wells suitable for measurement or sites suitable for drilling observation wells was beyond the scope of this study.

\section{REFERENCES CITED}

Bauer, Glenn, 1993, High-level ground water discovered in Kona: Water Resource Bulletin 4 [published by Division of Water Management, Hawaii State Department of Land and Natural Resources], p. 2, 4.

Bear, Jacob, 1979, Hydraulics of groundwater: New York, McGraw-Hill Inc., 569 p.

Eyre, P.R., 1987, Source of salts in the Waianae part of the Pearl Harbor aquifer near Barbers Point water tunnel, Oahu, Hawaii: U.S. Geological Survey Water-Resources Investigations Report 87-4247, 48 p.

Gingerich, S.B., and Izuka, S.K., 1997, Construction, geologic log, and aquifer tests of the Northwest Kilohana monitor well (State well 2-0126-01), Lihue, Kauai, Hawaii: U.S. Geological Survey Open-File Report 97$40,20 \mathrm{p}$.

Heath, R.C., 1976, Design of ground-water level observationwell programs, Ground Water v. 14/2, p. 71-77.

Hunt, C.D., Jr., 1996, Geohydrology of the island of Oahu, Hawaii: U.S. Geological Survey Professional Paper 1412-B, $54 \mathrm{p}$.
Hunt, C.D., Jr., Ewart, C.J., and Voss, C.I., 1988, Region 27, Hawaiian Islands in Back, William, Rosenhein, J.S., and Seaber, P.R., eds., Hydrogeology: Boulder, Colorado, Geological Society of America, The Geology of North America v. O-2, p. 255-262.

Langenheim, V.A.M., and Clague, D.A., 1987, Stratigraphic framework of volcanic rocks of the Hawaiian islands, chap. 1 of Decker, R.W., Wright, T.L., and Stauffer, P.H., eds., Volcanism in Hawaii: U.S. Geological Survey Professional Paper 1350, v. 1, p. 55-84.

Macdonald, G.A., Davis, D.A., and Cox, D.C., 1960, Geology and ground-water resources of the island of Kauai, Hawaii: Hawaii Division of Hydrography Bulletin 13, $212 \mathrm{p}$.

Matsuoka, Iwao, Kunishige, V.E., and Lum, M.G., 1992, Water resources data for Hawaii and other Pacific areas, water year 1991. Volume 1, Hawaii: U.S. Geological Survey Water-Data Report HI-91-1, 282 p.

Matsuoka, Iwao, Kunishige, V.E., and Lum, M.G., 1993, Water resources data for Hawaii and other Pacific areas, water year 1992. Volume 1, Hawaii: U.S. Geological Survey Water-Data Report HI-92-1, 350 p.

Presley, T.K., Sinton, J.M., and Pringle, M., 1997, Postshield volcanism and catastrophic mass wasting of the Waianae Volcano, Oahu, Hawaii: Bulletin of Volcanology, v. 58, no. 8 , p. 597-616.

Reilly, T.E., 1993, Analysis of ground-water systems in freshwater-saltwater environments, in Alley, W.M., ed., Regional ground-water quality: New York, Van Nostrand Reinhold, p. 443-469.

Soroos, R.L., and Ewart, C.J., 1979, Ground-water status report, Pearl Harbor area, 1978: U.S. Geological Survey Open-File Report 79-1542, 3 sheets.

State of Hawaii, Commission on Water Resource Management, 1992a, Oahu Water Management Plan: Prepared by Wilson Okamoto \& Associates, Inc. for the Department of General Planning, City and County of Honolulu, Review draft.

----, 1992b, Kauai County Water Use and Development Plan: Prepared by R.M. Towill Corporation for the Department of Water, County of Kauai, Review draft.

----, 1992c, Maui County Water Use and Development PlanIsland of Maui: Prepared by M \& E Pacific, Inc. for the Department of Water Supply, County of Maui, Review draft.

----, 1992d, Maui County Water Use and Development PlanIsland of Molokai: Prepared by M \& E Pacific, Inc. for the Department of Water Supply, County of Maui, Review draft.

---., 1992e, Hawaii County Water Use and Development Plan: Prepared by Megumi Kon, Inc. for the Department of Water Supply, County of Hawaii, Review draft. 
Stearns, H.T., and Macdonald, G.A., 1942, Geology and ground-water resources of the island of Maui, Hawaii: Hawaii Division of Hydrography Bulletin 7, 344 p.

Stearns, H.T., and Vaksvik, K.N., 1935, Geology and ground-water resources of the island of Oahu, Hawaii: Hawaii Division of Hydrography Bulletin 1, $479 \mathrm{p}$.

Takasaki, K.J., and Mink, J.F., 1985, Evaluation of major dike-impounded ground-water reservoirs, island of Oahu: U.S. Geological Survey Water-Supply Paper 2217, $77 \mathrm{p}$.

U.S. Geological Survey, Office of Water-Data Coordination, 1980, National handbook of recommended methods for water-data acquisition: Reston, VA. 